\title{
An Assessment of Management Practices of Wood and Wood-Related Wastes in the Urban Environment
}

Solid Waste Association of North America Silver Spring, Maryland

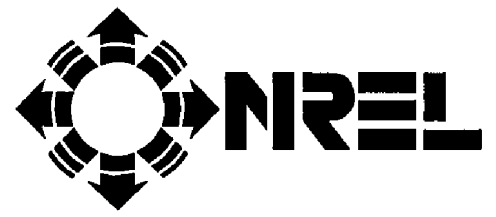

National Renewable Energy Laboratory 1617 Cole Boulevard Golden, Colorado 80401-3393

A national laboratory of the U.S. Department of Energy Managed by Midwest Research Institute for the U.S. Department of Energy under Contract No. DE-AC36-83CH10093 


\section{An Assessment of Management Practices of Wood and Wood-Related Wastes in the Urban Environment}

Solid Waste Association of North America Silver Spring, Maryland

NREL Technical Monitor: Philip Shepherd

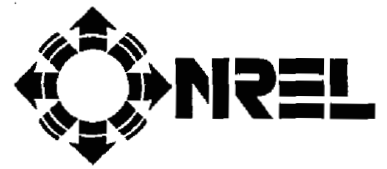

National Renewable Energy Laboratory 1617 Cole Boulevard Golden, Colorado 80401-3393

A national laboratory of the U.S. Department of Energy Managed by Midwest Research Institute for the U.S. Department of Energy under Contract No. DE-AC36-83CH10093

Prepared under Subcontract No. AAE-4-14077-01

February 1996 


\section{NOTICE}

This report was prepared as an account of work sponsored by an agency of the United States government. Neither the United States government nor any agency thereof, nor any of their employees, makes any warranty, express or implied, or assumes any legal liability or responsibility for the accuracy, completeness, or usefulness of any information, apparatus, product, or process disclosed, or represents that its use would not infringe privately owned rights. Reference herein to any specific commercial product, process, or service by trade name, trademark, manufacturer, or otherwise does not necessarily constitute or imply its endorsement, recommendation, or favoring by the United States government or any agency thereof. The views and opinions of authors expressed herein do not necessarily state or reflect those of the United States government or any agency thereof.

Available to DOE and DOE contractors from:

Office of Scientific and Technical information (OSTI)

P.O. Box 62

Oak Ridge, TN 37831

Prices available by calling (615) $576-8401$

Available to the public from:

National Technical Information Service (NTIS)

U.S. Department of Commerce

5285 Port Royal Road

Springfield, VA 22161

(703) $487-4650$ 


\section{Executive Summary}

\section{DESCRIPTION OF PROJECT}

The U.S. Environmental Protection Agency estimates that yard waste ${ }^{1}$ accounts for approximately $16 \%$ of the municipal solid waste (MSW) stream (U.S. EPA, 1994). Until recently, specific data and related information on this component of the (MSW) stream has been limited. The purposes of this study, phase two of the three-phase assessment of urban wood waste issues, are to assess and describe current alternatives to landfills for urban wood waste management; provide guidance on the management of urban wood waste to organizations that produce or manage wood waste; and clarify state regulatory and policy positions affecting these organizations.

For this study, urban wood waste is defined as solid waste generated by tree and landscape maintenance services (public and private). Urban wood waste includes the following materials: unchipped mixed wood, unchipped logs, and unchipped tops and brush; clearing and grubbing waste; fall leaves and grass clippings; and chips and whole stumps. Construction and demolition debris and consumer-generated yard waste are not included in this study. Generators of urban wood waste include various organizations: municipal, county, and commercial tree care divisions; nurseries, orchards, and golf courses; municipal park and recreation departments; and electric and telephone utility power line maintenance, excavator and land clearance, and landscape organizations.

\section{SUMMARY OF FINDINGS}

\section{Federal Regulations}

While there are some regulations at the federal level that have an impact on urban wood waste management, their effect to date has been minimal. The statutes affecting urban wood waste management include the Clean Air Act, the Resource Conservation and Recovery Act, the Federal Water Pollution Control Act (Clean Water Act), and the Comprehensive National Energy Policy Act.

\section{State Regulations}

State controls on urban wood waste management are significant, and expanding. Thirty states have regulations regarding the management of urban wood waste. Twenty of those states have in place, or are considering, legislation that bans wood wastes from being disposed of in (MSW) disposal facilities; four of the states include wood wastes in state mandated recycling and diversion goals; and one state requires wood waste to be source separated (see Table ES-1, Summary of Urban Wood Waste Legislation).

\footnotetext{
'U.S. EPA defines yard waste as "yard trimmings" which includes "grass, leaves and tree brush trimmings from residential, institutional, and commercial sources."
} 
Table ES-1. SUMMARY OF URBAN WOOD WASTE LEGISLATION

[For states that have banned or plan to ban yard or urban wood waste from (MSW) disposal facilities (MSWDFs)]

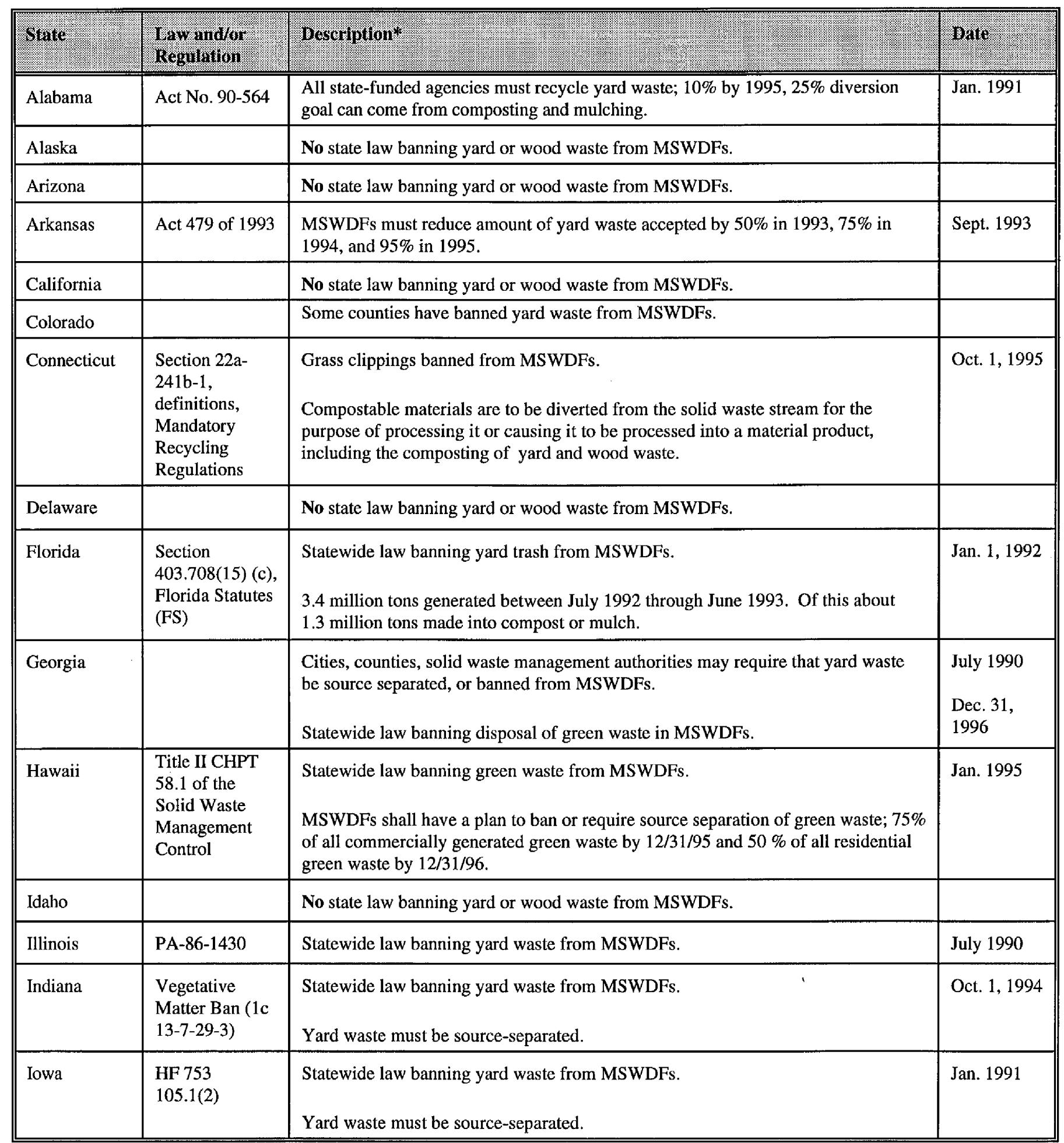

* For these tables, the term yard waste, green waste, yard trimmings etc. usually encompasses wood or wood-related waste. 


\begin{tabular}{|c|c|c|c|}
\hline Sule & rawangror & Bescriptiont: & Date \\
\hline Kansas & HB 2801 & $\begin{array}{l}\text { Requires counties in Kansas to design a plan that schedules waste reduction } \\
\text { goals. Composting and management of yard waste are to be part of this plan. }\end{array}$ & \\
\hline Kentucky & & No state law banning yard or wood waste from MSWDFs. & \\
\hline Maine & & No state law banning yard or wood waste from MSWDFs. & \\
\hline Maryland & H 1088 & $\begin{array}{l}\text { Source-separated yard waste banned from refuse disposal systems, unless it is } \\
\text { to be composted or mulched. }\end{array}$ & Oct. 1992 \\
\hline Michigan & $\begin{array}{l}\text { SWMA, } 1978 \text { PA } \\
641\end{array}$ & $\begin{array}{l}\text { Partial yard waste ban from disposal in MSWDFs took effect. } \\
\text { Total yard waste ban from disposal in MSWDFs. }\end{array}$ & $\begin{array}{l}\text { Mar. 28, } \\
1993 \\
\text { Mar. 28, } \\
1995\end{array}$ \\
\hline Minnesota & $\begin{array}{l}\text { Waste } \\
\text { Management Acts } \\
\text { Amendments } 1988 \\
\text { 115A.931 }\end{array}$ & $\begin{array}{l}\text { Yard waste may not be disposed of in mixed (MSW), in a disposal facility, or in } \\
\text { a resource recovery facility except for the purposes of composting or co- } \\
\text { composting. }\end{array}$ & 1989 \\
\hline Mississippi & & No state law banning yard waste disposal in MSWDFs. & \\
\hline Missouri & $\begin{array}{l}\text { SB } 530(1990) \\
\text { now incorporated } \\
\text { into Missouri } \\
\text { Solid Waste Law. }\end{array}$ & $\begin{array}{l}\text { State law banning yard waste from MSWDFs. } \\
\text { Designed to encourage county cooperation and local responsibility in order to } \\
\text { achieve } 40 \% \text { reduction in the amount of solid waste disposed in Missouri } \\
\text { landfills by the year } 1988 .\end{array}$ & Jan. 1992 \\
\hline Nevada & $\begin{array}{l}\text { Nevada Adim. } \\
\text { Code (NAC) } \\
444.731\end{array}$ & $\begin{array}{l}\text { No state law banning yard or wood waste from MSWDFs. } \\
\text { Wood waste is regulated indirectly through Class III (construction and } \\
\text { demolition debris) industrial landfills. }\end{array}$ & \\
\hline $\begin{array}{l}\text { New } \\
\text { Hampshire }\end{array}$ & $\begin{array}{l}\text { HB 646-NF RSA } \\
149-\mathrm{M}: 22, \text { VII }\end{array}$ & Statewide law banning yard waste from MSWDFs and incinerators. & July 1993 \\
\hline New Jersey & PL 1987,C.102 & $\begin{array}{l}\text { Leaves banned from MSWDFs. Many municipalities have initiated bans of yard } \\
\text { waste from MSWDFs. }\end{array}$ & Sept. 1988 \\
\hline New Mexico & & $\begin{array}{l}\text { No state law banning yard or wood waste from MSWDFs. } \\
\text { State encourages chipping of wood waste materials for use as mulch. }\end{array}$ & \\
\hline
\end{tabular}

* For these tables, the term yard waste, green waste, yard trimmings etc. usually encompasses wood or wood-related waste. 


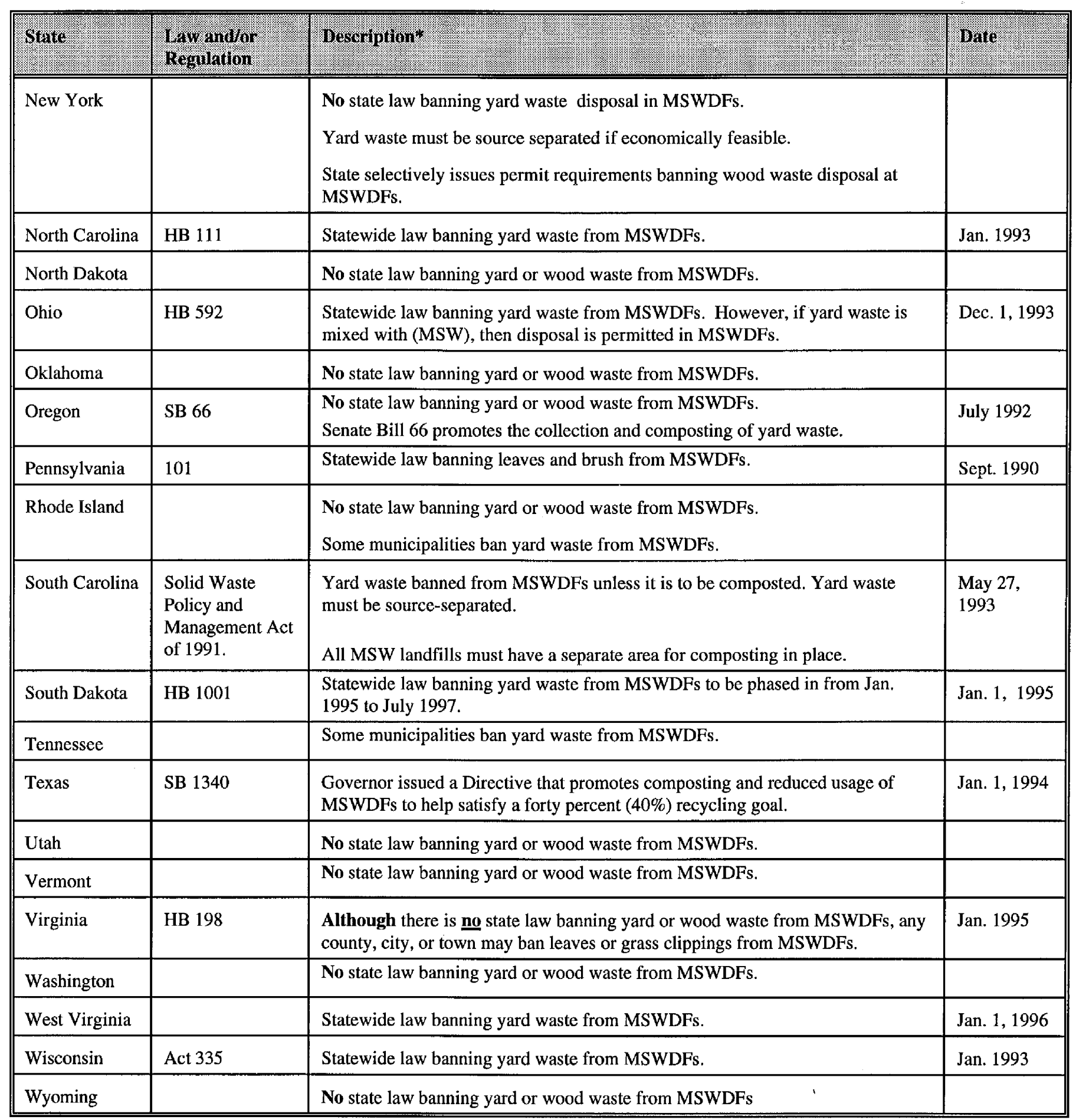

* For these tables, the term yard waste, green waste, yard trimmings etc. usually encompasses wood or wood-related waste. 


\section{The Effect Of Legislative And Policy Initiatives}

\section{Opportunities}

Urban wood waste management professionals indicated that the principle incentive for establishing and operating wood waste management systems is the increasing amount of state, county, and local laws and regulations prohibiting the disposal of urban wood waste in (MSW) disposal facilities. Urban wood waste management professionals indicated that opportunities to obtain contracts for wood waste management services from many local governments are increasing as regulations are implemented.

\section{Constraints}

While the opportunities to establish markets for urban wood waste are increasing, there are also increasing constraints to establishing private and public urban wood waste management programs. The costs involved in the operation and maintenance of an urban wood waste management system were indicated by $57.8 \%$ of the urban wood waste managers as the primary constraint to success (see Figure ES-1). The economics of urban wood waste management depends on a variety of factors, including operation and maintenance expenses, economies-of-scale, funding, start-up costs, collection fees, equipment costs, cost of debagging, source separation of materials, and endmarkets for products. These factors increased the overall cost of the operation or resulted in a decreased value of end products. Economic factors have forced some organizations to operate at the break-even threshold or face closure of their urban wood waste management systems.

The second leading constraint cited $(32.4 \%)$ was regulatory and permitting requirements by federal, state, county and local governments. Urban wood waste management systems are subjected to increasing laws, regulations, and permitting requirements. The difficulty with permitting or regulating an urban wood waste management facility often relates to inconsistent or deficient definitions for this relatively new management practice. Many jurisdictions permit and regulate urban wood waste as yard waste, usually including grass and leaves, or as a (MSW). Both of these classifications are incompatible with urban wood waste management. The result is that the permitting process often takes longer than it would under a regime tailored to urban wood wastes.

The last category of constraints is community awareness issues, including public resistance to facility siting and operation; contamination of incoming or outgoing materials; and odor complaints. Problems involving public relations are generally perceived as particularly contentious issues to the establishment and operation of an urban wood waste management system. However, based on responses from urban wood waste management professionals $(9.8 \%$ indicated public relations as a problem), problems involving the public, or the public's perceptions of urban wood waste management systems, are less significant for successful operations, relative to economic factors and regulatory and permitting issues. 


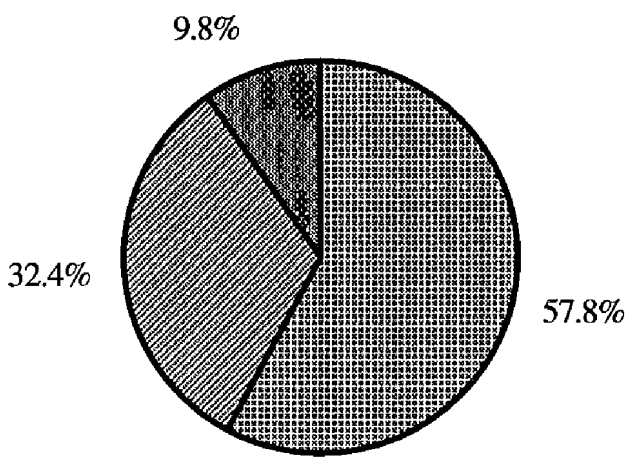

Economic Factors $57.8 \%$

Regulations and Permiting $32.4 \%$

Public Relations $9.8 \%$

Figure ES-1. Constraints cited by urban wood waste managers

\section{How State Initiatives Affect the Generator's Ability to Find Management Solutions}

There were 207 useful responses to a mailing to 1000 International Society of Arboriculture(ISA) members. Fifty-eight percent of the responses were from states that currently regulate wood waste operations. Fifty-four percent of these responses said that state regulations have decreased the disposal options available, with $27 \%$ responding that options have stayed the same. The remaining $19 \%$ stated options have gone up with the implementation of state regulations. Many of the responses stating no change in disposal options indicated that travel distances and tipping fees have increased. Due to the low number of participants, no definite conclusions can be drawn about national trends in urban wood waste management.

\section{Current and Future Directions of Urban Wood Waste Management Regulations}

The regulation of urban wood waste management is expected to increase at the state and local level. The number of states that require urban wood waste to be managed in a manner other than landfilling or open burning undoubtedly will increase. More than half of the states in this country (30) have implemented regulations within the past 10 years, and other states may follow suit. Some states are trying to extend the life of existing landfills by prohibiting the disposal of certain wastes, including urban wood waste.

\section{Assessment of the Quantity and Character of Urban Wood Wastes}

\section{Generation of Urban Wood Waste}

An extensive study of the generation of urban wood waste was conducted by the NEOS

Corporation for the ISA Research Trust, Allegheny Power Service Corporation, and the National Arborist Foundation. This September 1994 study concluded that approximately 200 million cubic yards of urban wood waste are created annually. Most (73\%) of the 200 million cubic yards were found to be generated by commercial tree care and lawncare and landscape organizations. The ISA study also concluded that $67 \%$ of the urban wood waste generated yearly is in the form of chips. The study intended to exclude municipally collected residentially generated wood waste; however, a small portion may have been recorded . 


\section{Assessment of Current Urban Wood Waste Management Practices}

\section{Major Findings}

Fourteen wood waste management facilities were assessed, with information provided in a case study format. These facilities do not represent all management methods. However, they do provide snapshots that indicate the range of management methods currently being used. Many systems mulch and compost their urban wood wastes (see Table ES-2) because state initiatives promote composting, demand for mulch products is currently high, and composting and mulching programs are relatively easy to implement.

\section{Table ES-2. Urban Wood Waste Management Practices of Case Study Participants ${ }^{2}$}

\begin{tabular}{||l|c|c||}
\hline Management Practice & \# of Facilities & Percent \\
\hline Mulch & 9 & 64 \\
\hline Compost & 9 & 64 \\
\hline Wood-fuel & 5 & 36 \\
\hline Land-applied & 2 & 14 \\
\hline Given Away & 4 & 29 \\
\hline Mobile Grind & 1 & 7 \\
\hline
\end{tabular}

An assessment of the case studies indicates that, while these facilities are very different, they share a number of commonalities that help make the facilities successful. These include tailoring the project within the context of the community in which it is implemented; forming cooperative efforts between the public and private sector; maintaining flexibility in both materials processing and products; conducting research into potential markets during the planning stage; undertaking continuous research and experimentation especially in markets and products; achieving and maintaining a good reputation with the public as a good neighbor and producer of a high quality product; and working closely with local and state regulatory and enforcement officials.

Several types of management applications that were considered, but were not included in the case studies. These included: utilization of landfills, biosolids composting, co-combustion, and bioconversion systems.

\section{Methods of Urban Wood Waste Management}

The September, 1994 ISA Research Trust study also made a detailed inspection of current disposal methods for urban wood waste. The study concluded, as stated in Table ES-3, that the main disposal method for urban wood waste is to give it away (42.7\%) followed by landfilling $(17.3 \%)$ and selling it (12.2\%). Urban wood waste is most commonly sold as mulch (41\%) and firewood $(25 \%)$.

\footnotetext{
${ }^{2}$ All case study participants utilize more than one urban wood waste management practice
} 
Table ES-3. National Estimate of Urban Wood Waste Management Methods

\begin{tabular}{||l|r|}
\hline \multicolumn{1}{|c|}{ Disposal Method } & \multicolumn{1}{c|}{$\begin{array}{c}\text { Quantity } \\
\text { (Thousand Cubic } \\
\text { Yards per Year) }\end{array}$} \\
\hline Given Away & 84,220 \\
\hline Landfilled & 34,088 \\
\hline Sold & 24,063 \\
As Boiler Fuel & 4,010 \\
As Compost & 2,005 \\
As Mulch & 10,026 \\
As Wood Products & 1,805 \\
As Firewood & 6,016 \\
Other & 200 \\
\hline Left On-site & 22,058 \\
\hline Sent to Recycling Center & 12,031 \\
\hline Burned for Energy & 6,016 \\
\hline Stock Piled/Used On-site & 8,021 \\
\hline Incinerated & 602 \\
\hline Other & 6,016 \\
\hline Total & 197,116 \\
\hline
\end{tabular}

Source: ISA Research Trust, 1994. 


\section{Table of Contents}

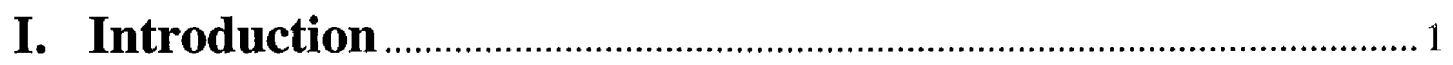

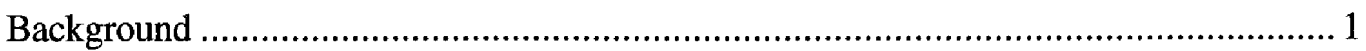

Managing Urban Wood Waste in Today's Regulatory Climate ........................... 1

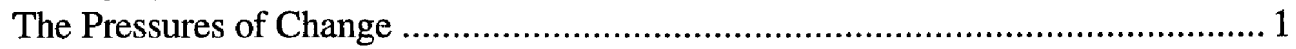

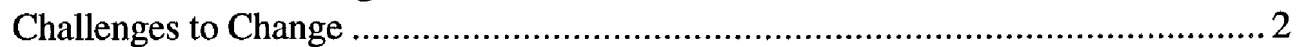

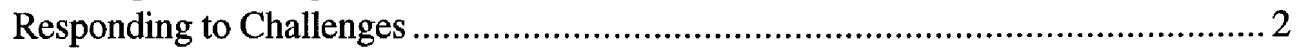

Finding Answers to Questions................................................................... 2

Project Description .......................................................................... 3

Assessment of Current Regulatory and Policy Positions ...................................... 3

Assessment of Current Management Practices.................................................... 3

Summary of Project Methodology ...................................................................... 4

Management Applications that Were Not Included ........................................... 4

\section{Federal and State Policies, Legislation and Regulations That} Affect Urban Wood Waste Management ...................................... 5

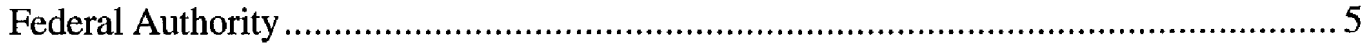

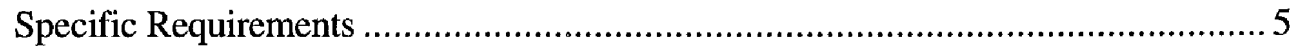

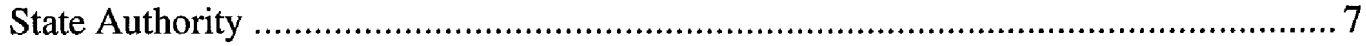

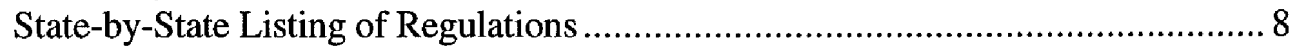

\section{The Effect of Legislative and Policy Initiatives …………….....29}

Current Opportunities for and Constraints to Establishing or

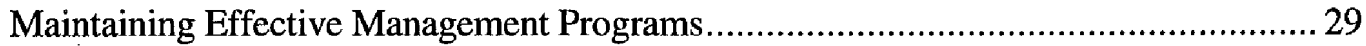

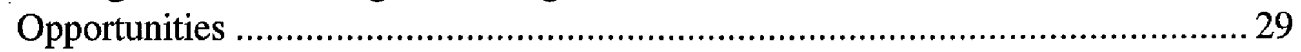

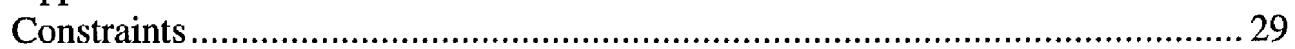

How State Initiatives Affect the Generators Ability to Find Management Solutions ..... 32

Current and Future Directions of the Regulation of Urban Wood Waste Management 32

\section{IV.Assessment of the Quantity and Character of}

Urban Wood Wastes .................................................................................34

Generation of Urban Wood Waste ...................................................................... 34

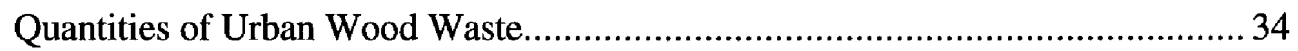

Types of Urban Wood Waste Generated ........................................................ 36

Trends in Urban Wood Waste Generation ..................................................... 37

\section{Assessment of Current Urban Wood Waste}

Management Practices ........................................................................... 38

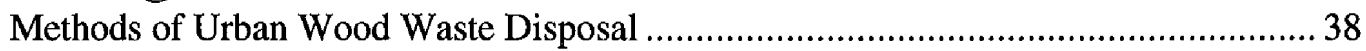

Current Urban Wood Waste Management Methods ........................................... 38

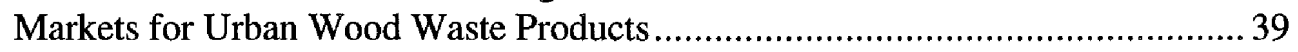

Trends in Urban Wood Waste Management .................................................. 40

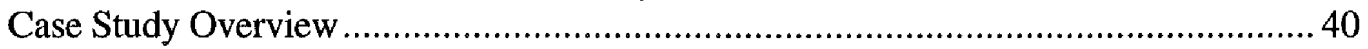




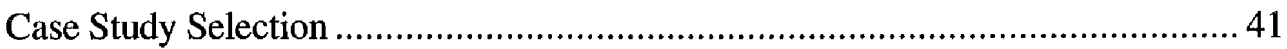

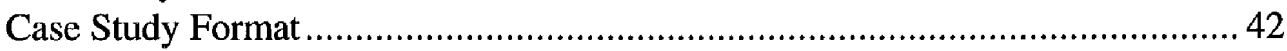

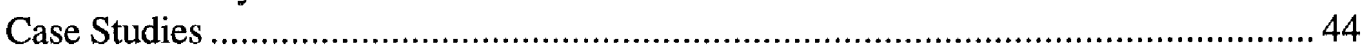

Carroll County Landfill, Carroll County, MD ............................................ 44

Decatur-Morgan County Landfill, Decatur, AL .............................................. 46

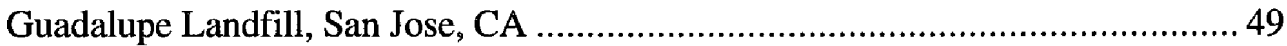

Greater Cleveland Ecology Association, Cleveland, $\mathrm{OH}$...............................55

GreenCycle of the Northeast, West Hartford, CT ......................................... 55

Mecklenburg County, Compost Central, Charlotte, NC ................................. 57

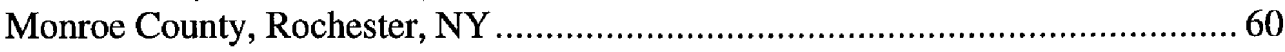

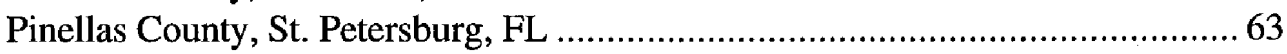

Prince George's County Landfill, Prince George's County, MD ........................ 65

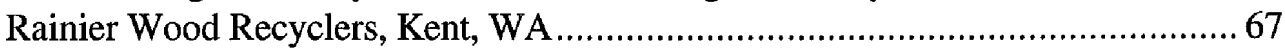

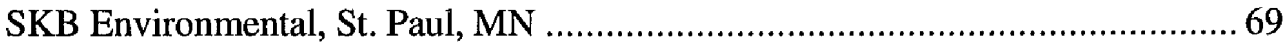

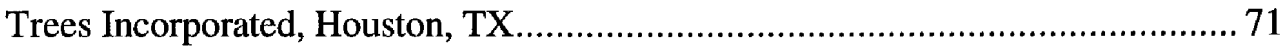

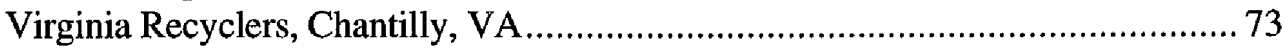

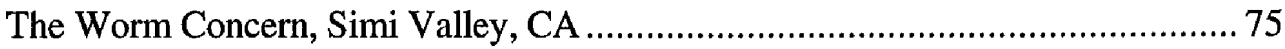

VI.Conclusions

Appendices

A. Project Methodology

B. Case Study Format

C. State Contact Listing

\section{VII.References}




\section{List of Tables}

ES-1, Summary of Urban Wood Waste Legislation ...........................................................iii

ES-2, Urban Wood Waste Management Practices of Case Study Participants......................viii

ES-3, National Estimate of Urban Wood Waste Management Methods.................................ix

III-1, Management Structure of Wood Waste Assessment Respondents ..............................29

III-2, Constraints to Wood Waste Management .................................................................. 31

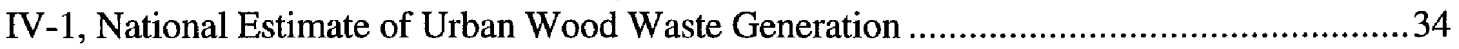

IV-2, National Estimate of Urban Wood Waste Generation by Type...................................36

V-1, Estimate of Urban Wood Waste Management Methods in the United States ....................38

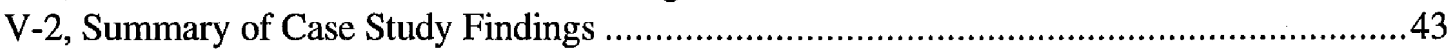

V-3, Capital Costs for Start-up in 1990-1991,

Decatur-Morgan County Landfill, Decatur, Alabama ...................................................... 47

V-4, Annual Costs for the Last Budget Year,

Decatur-Morgan County Landfill, Decatur, Alabama ........................................................47

V-5, Compost Central, Yearly Budget, Charlotte, North Carolina........................................59

V-6, Comprehensive Recycling Analysis of Yard Waste Statistics and Projections,

Monroe County, New York, 1995.

\section{List of Figures}

ES-1, Constraints cited by urban wood waste managers ...................................................vii

III-1, Effects of state regulation on urban wood waste disposal options ................................32

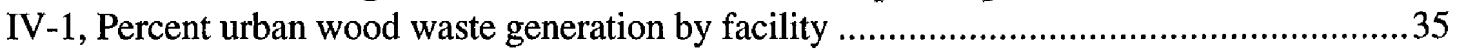

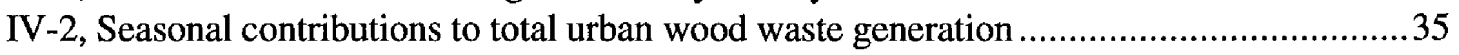

IV-3, National estimate of urban wood waste formation by type ........................................ 36

V-1, Estimate of wood waste management methods in the United States ...............................39

V-2, Distribution of urban wood waste product markets in the United States........................40

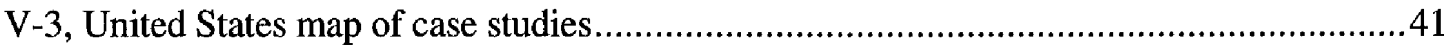




\section{Background}

\section{Introduction}

\section{Managing Urban Wood Waste in Today's Regulatory Climate}

The U. S. Environmental Protection Agency estimates that yard waste ${ }^{3}$ accounts for approximately $16 \%$, by weight, of the (MSW) stream (U.S. EPA, 1994). Until recently, specific data and related information on this component has been non-existent. The management of urban wood wastes has not, until now, been studied in any detail. Descriptions of current management practices are primarily anecdotal. This study was directed at assessing the magnitude of problems associated with managing urban wood wastes and the management alternatives available.

Historically, open burning of urban wood waste was a common practice; however, the passage of the Clean Air Act and its subsequent implementation has resulted in this practice being banned in urban settings. Landfilling or open dumping of urban wood waste also has been a common management method and continues to be widely used. Mulching and composting of selected segments of urban wood wastes has increased in popularity in the past decade but because of the costs and technical limitations is not replacing landfilling as the method of choice; and there is some use of urban wood waste as an energy source through controlled combustion as a biomass fuel.

\section{The Pressures for Change}

The past prevalent management practices for urban wood waste, that include landfilling and open burning, are being increasingly restricted. The reasons for this include the following:

- Open dumping of urban wood waste is being phased out in most states due to increasing regulations.

- State regulatory agencies are imposing landfill diversion (of recyclable materials) rates on (MSW) management (MSWM) systems.

- Since yard waste composes almost $16 \%$ of MSW, regulatory agencies are beginning to include yard waste in recycling goals (U.S. EPA, 1994).

- State regulatory agencies are establishing mandatory recycling rates for MSWM systems and banning certain solid wastes, including urban wood waste, from landfills.

\section{Challenges to Change}

Local governments are charged by state governments to protect human health and the environment within their jurisdictions. One measure to carry out this mandate is the management, either directly or through the use of private service providers, of (MSW)s. In many states, local governments are being required to develop integrated (MSW) management plans; meet either landfill diversion or recycling rates; and ban certain materials from their landfills. One of the most common materials to be banned or diverted from landfills to other management methods is urban wood waste. The banning or diversion of urban wood wastes challenges local governments to find other management methods for urban wood waste.

\footnotetext{
${ }^{3}$ U.S. EPA defines yard waste as "yard trimmings" which includes "grass, leaves and tree brush trimmings from residential, institutional, and commercial sources."
} 


\section{Responding to the Challenges}

In order to address these challenges, the following questions need to be addressed:

- How big is the urban wood waste management resource on a national, regional, and local basis?

- What are the quantities and character of urban wood waste?

- Is there a problem, and do the various participants in the management, regulatory and policy making processes understand it and the solutions available?

- What are the current options for management when landfills are not available?

- What are the economic, environmental and operational limitations to these methods?

- What are the implementation realities of each of these methods?

- In both the short and long term, what are the needs of the generators and management systems to eventually provide management methods and options that make environmental, resource, energy, and economic sense?

\section{Finding Answers to the Questions}

The International Society of Arboriculture Research Trust (ISA Research Trust) and the Solid Waste Association of North America (SWANA) are conducting a three-part research effort to address the questions listed above. The three parts are as follows:

Part 1: Assess the quantities and character of urban wood wastes.

Part 2: Assess current regulatory and policy positions, and current management practices and options.

Part 3: Assess future opportunities for urban wood waste management and provide recommendations for action.

ISA Research Trust is an association of individuals and organizations involved in the management of forests; utilization of forestry products as wood and paper products, and recreational uses; the clearing of forests for various purposes; and lawn and landscape services and tree services. The members of ISA generate large quantities of wood wastes, nursery (vegetative, woody, etc.) wastes and a variety of other vegetative, woody, green solid wastes. SWANA is a non-profit educational association of (MSW) management professionals. SWANA's mission is to advance the practice of environmentally and economically sound (MSW) management.

\section{Part 1 - Assessment of the Quantity and Character of Urban Wood Wastes}

This task was recently completed and is described in "Final Report, Urban Tree Residues: Results of the First National Inventory." The report, completed by and available from ISA Research Trust, quantitatively assessed the amount of wood and wood-related waste currently being produced in this country. This part of the study addressed the question, "What are the quantities and character of urban wood waste?" 
Part 2 - Assessment of Current Regulatory and Policy Positions, and Current Management Practices and Options

Part 2 is the subject of this report and it addresses the following questions:

1. What current federal and state regulations and policies affect the ability of the arboriculture industry and MSWM industry to properly manage urban wood waste?

2. What are the current options for management when landfills are not available?

3. What are the economic, environmental and operational limitations to these methods; and what are the implementation realities of each of these methods?

Part 3 - Assessment of Future Needs for Urban Wood Waste Management, and Recommendations for Action

The final part will seek to answer the following:

In both the short and long term, what are the needs to eventually provide management methods and options that make environmental, resource, energy, and economic sense?

\section{Project Description}

Urban wood waste is defined as solid waste generated by tree and landscape maintenance services (public and private). Urban wood waste includes unchipped mixed wood, unchipped logs, and unchipped tops and brush; clearing and grubbing waste; fall leaves and grass clippings; chips and whole stumps. Construction and demolition (C\&D) debris are not included in this study. Generators of urban wood waste include municipal, county, and commercial tree care divisions; nurseries, orchards, and golf courses; municipal park and recreation departments; and electric and telephone utility power line maintenance; excavator and land clearance, and landscapers.

The purposes of the study were to do the following:

- Assess and describe current alternatives to landfills for urban wood waste management,

- Assess the economic, environmental, and operational limitations of landfill alternatives,

- Assess the implementation realities of these options, and

- Clarify state regulations and policies affecting these organizations.

\section{Assessment of Current Regulatory and Policy Positions}

An assessment of current federal and state regulatory, legislative, and policy initiatives disclosed how they may limit management options for generators of urban wood waste and management systems for urban wood waste.

\section{Assessment of Current Management Practices}

This topic was conducted through a series of case studies that defined current management practices and assessed the findings. The results can be used by readers of this report to help guide them in planning and implementing urban wood waste management programs. To assure 
uniformity of the results, a case study format was developed and pilot case studies were conducted. The case study format includes the following:

- Background: a short description of quantities and types of urban wood waste being managed; and the organizations involved.

- Regulatory/Policy Issues: a discussion of regulatory and policy initiatives that have affected the organizations involved in the management of urban wood waste.

- Management Practices: a description with some data of the management technology, system and practices involved, with flow charts and material balances where possible.

- Costs and Economics: a summary of costs and economic variables associated with the management system.

- Lessons Learned: insights and advice from professionals in the urban wood waste management field.

\section{SUMMARY OF PROJECT METHODOLOGY}

The project methodology included use of an Advisory Group, contacts with all 50 states to determine current regulatory circumstances, selection of case study sites, and the specific case studies.

The project was guided by the Advisory Group, with a diverse composition, to provide views from the perspective of urban wood waste generators, managers, and regulators. They provided input on a range of issues, particularly in the area of the format for case studies and sites for case studies.

Gathering information from all 50 States involved contacting state agencies and state officials for regulatory information. Federal regulations were obtained by researching previous work done on the subject, in part by using data bases. Targeted SWANA members were contacted to assess opportunities for and constraints to establishing management programs.

Information was collected from more than 50 potential case study sites. This information was collected through a variety of means, including the Advisory Group, solicitation of information in various publications, attendance at a biomass conference, use of state lists of management facilities, and a search of literature relating to urban wood waste management.

The case studies focused on facilities using the following management methods: mulching, composting, combustion, and land application. However, the case studies also included facilities that used mobile grinding and giving away the processed wood waste.

\section{Management Applications That Were Not Included}

For various reasons, some management applications were explored but were not selected as a case study application. These included of landfills, biosolids composting, co-combustion, and bioconversion systems. 


\section{Federal and State Policies, Legislation, and Regulations That Affect Urban Wood Waste Management}

\section{Federal Authority}

The principle federal waste-management statute (the Solid Waste Disposal Act, or SWDA) allows states to adopt rules that are equivalent to or more stringent than those set by the federal government. As a result, requirements for management of solid waste vary from state to state, and even from municipality to municipality. Therefore, it is necessary to assess federal, state and local regulations to get an accurate picture of the current state of regulations governing urban wood waste management.

The regulation of (MSW) management in the United States is a function of state and local government. Through federal water pollution (the Clean Water Act) and air pollution (the Clean Air Act) legislation, emissions from solid waste management facilities are regulated. In both instances states may assume authority over these emissions if they establish regulatory programs that are equal to or more stringent than the federal regulations.

Other regulatory aspects of the regulation of (MSW) management facilities rests principally with state government. The SWDA ${ }^{4}$, as amended ${ }^{5}$, by a variety of amendments since its enactment in 1965 , does not provide to the federal government the same authorities as the Clean Water Act and the Clean Air Act. SWDA until its 1984 amendments authorized research, development, training, and assistance. The 1984 amendments granted to the federal government regulatory and enforcement over (MSW) landfills. Again, states are charged with establishing regulatory and permit programs equal to, or more stringent than, federal landfill regulations.

\section{Specific Requirements}

\section{Resource Conservation and Recovery Act (RCRA)}

There are no specific provisions for wood wastes in RCRA. Solid waste is defined in RCRA as "Any garbage, refuse, sludge, from a waste treatment plant, water supply treatment plant, or air pollution control facility and other discarded material, including solid, liquid, semisolid, or contained gaseous material resulting from industrial, commercial, mining, and agricultural operations, and from community activities, but does not include solid or dissolved material in domestic sewage, or solid or dissolved material in irrigation return flows or industrial discharges that are point sources subject to permits under section 402 of the Federal Water Pollution Control Act, as amended, or source, special nuclear, or byproduct material as defined by the Atomic Energy Act of 1954, as amended." Urban wood wastes, like any other solid waste must be tested to determine if it is a hazardous waste. If a wood waste tests as a hazardous waste it is subject to the hazardous waste provisions of Subtitle $\mathrm{C}$ of RCRA. If it does not test as a hazardous waste it is subject to any solid waste management provisions of Subtitle D of RCRA. There are no specific

\footnotetext{
${ }^{4} 1965$ Solid Waste Disposal Act (SWDA)

${ }^{5} 1970$ Amendments to SWDA, the Resource Recovery Act (RRA)

1976 Amendments to SWDA, the Resource Conservation and Recovery Act (RCRA)

1984 Amendments to SWDA, the Hazardous and Solid Waste Amendments (HSWA)
} 
regulatory requirements for wood wastes under Subtitle D. Regulation therefore rests in the hands of state government.

\section{The Clean Air Act (CAA)}

There are no specific provisions for wood wastes in the CAA. The CAA authorized EPA to regulate emissions into the atmosphere. In doing so, EPA has established regulations for specific pollutants and combustion technologies. As such, urban wood wastes that are managed in a manner that would cause emissions regulated by the CAA to be released to the atmosphere would be subject to those regulations. Hazardous air pollutants (HAPS) such as benzene and formaldehyde that may be generated in the combustion of urban wood wastes are regulated under the CAA. States have been delegated to implement the emission regulations of the CAA. Urban wood wastes, like any other solid waste to be combusted, would be subject to state regulation, but no specific regulations for wood wastes exist.

\section{Comprehensive National Energy Policy Act (CNEPA)}

CNEPA was enacted to encourage the development of alternative energy options. CNEPA does not address specific energy sources such as bio-mass or urban wood wastes. Rather, CNEPA provides policies to open up energy markets to alternative energy sources. Implementation of CNEPA has been disappointing and current federal policy would indicate that alternate energy sources such as urban wood wastes can not expect any benefits to be derived from CNEPA.

\section{The Federal Water Pollution Control Act (Clean Water Act)}

There are no specific provisions in the Clean Water Act (CWA) that address urban wood wastes. Similar to the CAA, the CWA provides authority for EPA to regulate waste water discharges into the surface and navigable waters of the United States. In turn, this authority has been delegated to the states. Any management process for urban wood wastes that would result in waste water would be subject to the provisions of the CWA.

\section{National Pollution Discharge Elimination System (NPDES)}

NPDES, as a provision of the CWA, regulates discharges of waste waters to the navigable waters of the United States. Discharge standards are established under the provisions of NPDES. As in the balance of the CWA, provisions are not for specific wastes, but are rather for the discharges from waste water treatment systems. Again, this authority has been delegated to the states for implementation. 


\section{State Authority}

From the previous review of federal policies, legislation, and regulation it is clear that the role of the federal government relative to urban wood waste management is modest. Either through delegation of authorities of various provisions of federal legislation or no national attention, the states are the principal level of government that addresses urban wood waste management practices.

In conducting this study, therefore, attention was directed at the states to identify state by state what polices, legislation, or regulations were in place to address urban wood waste management. Information of these state practices was gathered with the assistance of the Association of State and Territorial Solid Waste Management Officials [ASTSWMO]. A state-by-state listing of the findings and a summary of the findings is included in the following pages of this report.

The results indicate the following:

- Sixty percent of the states have some regulations for urban wood waste management.

- Twenty of the states with regulations either have or are seriously considering banning urban wood wastes from landfills.

- Five states have authorized local governments to ban urban wood wastes from landfills.

- Four states included urban wood wastes in state-mandated recycling goals.

- One state requires urban wood waste to be source separated. 
NREL AAE-4-14077-01

\section{State by State Listing of Regulations}

\section{ALABAMA}

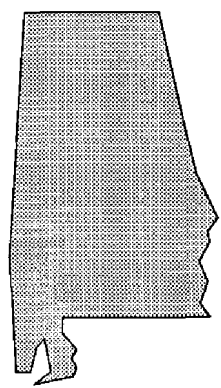

State Definition of Urban Wood Waste

- The State of Alabama defines urban wood waste under the 1969 Solid Waste Disposal Act as rubbish.

- Rubbish means nonputrescible solid waste, excluding ashes, consisting of both combustible and non-combustible waste. Combustible rubbish includes paper, rags, cartons, wood, furniture, rubber, plastics, yard trimmings, leaves and similar materials.

Laws and Regulations Affecting the Establishment and Operation of Urban Wood Waste Management Systems:

- Act No. 90-564 (January 1991). All state-funded agencies must recycle yard waste; ten percent $(10 \%)$ goal by 1995 . Twenty-five percent $(25 \%)$ of the overall recycling goal can come from composting and mulching.

\section{ALASKA}

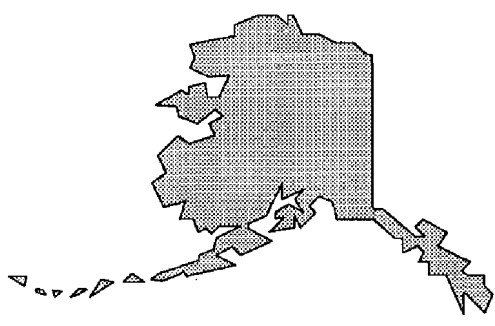

\section{State Definition of Urban Wood Waste}

- A definition of urban wood waste has not been obtained as of this time.

Laws and Regulations Affecting the Establishment and Operation of Urban Wood Waste Management Systems:

- No state law banning urban wood waste or yard waste disposal in (MSW) (MSW) disposal facilities.

\section{ARIZONA}

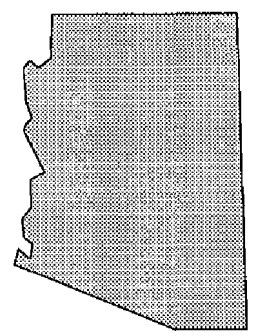

State Definition of Urban Wood Waste

- Urban wood waste is not defined by statute or rule in the State of Arizona.

Laws and Regulations Affecting the Establishment and Operation of Urban Wood Waste Management Systems:

- No state law banning urban wood waste or yard waste disposal in MSW disposal facilities. 


\section{ARKANSAS}

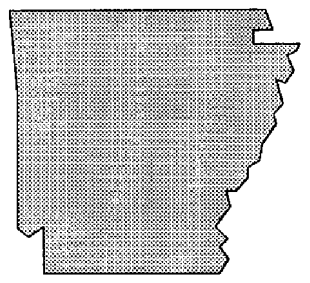

State Definition of Urban Wood Waste

- The State of Arkansas includes urban wood waste under the definition of Yard Waste.

- Yard Waste means grass clippings, leaves, and shrubbery trimmings.

Laws and Regulations Affecting the Establishment and Operation of Urban Wood Waste Management Systems:

- Act 479 of 1993 (September 1993). Solid waste disposal facilities must reduce amount of yard waste accepted by fifty percent (50\%) in 1993, seventy-five (75\%) in 1994, and ninety-five percent (95\%) by 1995.

\section{CALIFORNIA}

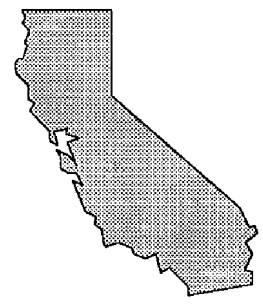

State Definition of Urban Wood Waste

- Urban wood waste is not defined by statute or rule in the State of California.

Laws and Regulations Affecting the Establishment and Operation of Urban Wood Waste Management Systems:

- No state law banning urban wood waste or yard waste disposal in MSW disposal facilities.

\section{COLORADO}

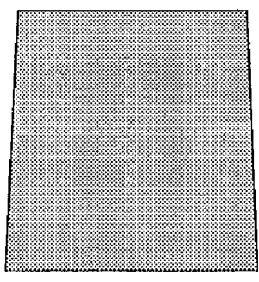

State Definition of Urban Wood Waste

- A definition of urban wood waste has not been obtained as of this time. 
Laws and Regulations Affecting the Establishment and Operation of Urban Wood Waste Management Systems:

- No state law banning urban wood waste or yard waste disposal in MSW disposal facilities.

- Some counties have banned yard waste from solid waste disposal facilities.

- In Denver, composting bins costing $\$ 100$ have been distributed to homeowners for $\$ 20$.

\section{CONNECTICUT}

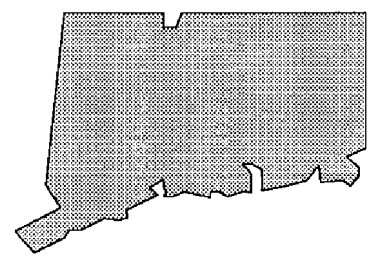

\section{State Definition of Urban Wood Waste}

- The State of Connecticut defines urban wood waste as Solid Waste and Bulky Waste.

- CT General Statutes; Chapter 446d, Section 22a-207 Solid Waste means solid, liquid, semisolid or contained gaseous material that is unwanted or discarded, including, but not limited to, demolition debris, material burned or processed at a resource recovery facility or incinerator, material processed at a recycling facility, and sludges or other residue from a water pollution abatement facility.

- Regulation of CT State Agencies, Section 22a-209-1 Bulky Waste means land clearing debris and waste, other than clean fill, resulting directly from demolition activities.

- However, under the Mandatory Recycling Regulations Definitions, urban wood waste is included as a compostable material that falls under the definition of Recycling that means to separate or divert an item or items from the solid waste stream for the purpose of processing it or causing it to be processed into a material product, including the production of compost in order to provide for disposition of the item or items in a manner, other than incineration or landfilling, that will best protect the environment.

Laws and Regulations Affecting the Establishment and Operation of Urban Wood Waste Management Systems:

- No state law banning urban wood waste or yard waste disposal in MSW disposal facilities.

- As a policy, the state generally does not regulate "clean" urban wood waste that is disposed on the property of generation as long as the disposal practices pose no threat to the environment or the waters of the state and is generated during normal maintenance activity.

- The state recommends the chipping of wood waste from the clearing of land and yards and the re-use of "clean" wood chips as landscape mulch, soil stabilization, compost bulking agent or other appropriate uses. 


\section{DELAWARE}

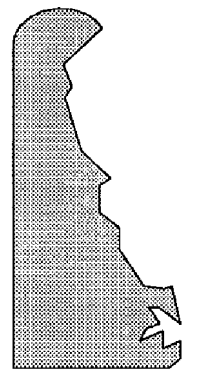

\section{State Definition of Urban Wood Waste}

- A definition of urban wood waste has not been obtained as of this time.

Laws and Regulations Affecting the Establishment and Operation of Urban Wood Waste Management Systems:

- No state law banning urban wood waste or yard waste disposal in MSW disposal facilities.

\section{FLORIDA}

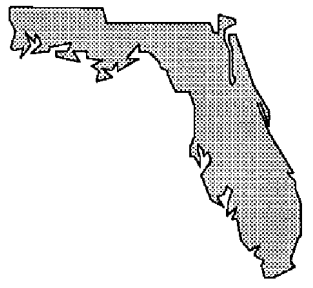

\section{State Definition of Urban Wood Waste}

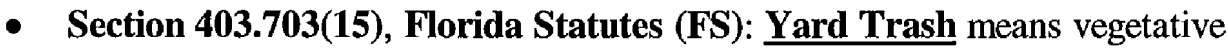
matter resulting from landscaping maintenance and land clearing operations.

- Section 403.703(32), Florida Administrative Code: Special Waste means solid wastes that require special handling and management, including, but not limited to, ..., yard trash, and biological wastes.

- Rule 62-701.200(90), Florida Administrative Code: Yard Trash means vegetative matter resulting from landscaping maintenance and land clearing operations and includes materials such as tree and shrub trimmings, grass clippings, palm fronds, trees and tree stumps.

Laws and Regulations Affecting the Establishment and Operation of Urban Wood Waste Management Systems:

- Section 403.708(15)(c),(FS) bans yard trash from disposal in solid waste disposal facilities as of January 1, 1992.

\section{GEORGIA}

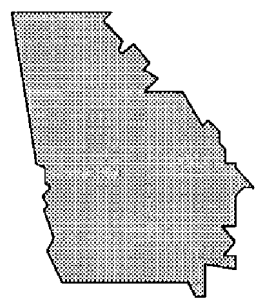

State Definition of Urban Wood Waste

- The State of Georgia includes urban wood waste under the definition of Yard Trimmings.

- Yard Trimmings are leaves, brush, grass clippings, shrub and tree prunings, discarded Christmas trees, nursery and greenhouse vegetative residuals, and vegetative matter resulting from landscaping development and maintenance other than mining, agricultural, and silvacultural operations. 
Laws and Regulations Affecting the Establishment and Operation of Urban Wood Waste Management Systems:

- Statewide law banning disposal of yard trimmings in solid waste disposal facilities as of December 31, 1994.

\section{HAWAII}

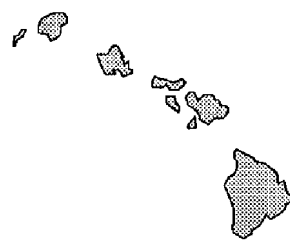

\section{State Definition of Urban Wood Waste}

- The State of Hawaii includes urban wood waste under the definition of Green Waste.

- Green Waste is solid waste that includes leaves, grass clippings, garden and yard wastes, tree trunks, holiday trees, tree trimmings, and/or prunings.

Laws and Regulations Affecting the Establishment and Operation of Urban Wood Waste Management Systems:

- Section 11-58.1-65. By December 31,1994, solid waste disposal facilities shall have a plan to ban or require source separation of green waste; seventy-five percent (75\%) of all commercially green waste by December 31,1995 and fifty percent $(50 \%)$ of all residential green waste by December 31, 1996.

- Title II Chapter. 58.1 (Solid Waste Management Control) Hawaii Administration Rules bans disposal of green waste in solid waste disposal facilities as of January 1, 1995.

\section{IDAHO}

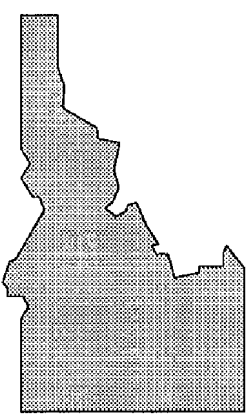

\section{State Definition of Urban Wood Waste}

- Idaho Code 39-7403(56) defines urban wood waste as solid waste consisting of pieces or particles generated as a by-product or waste from the manufacturing of wood products, handling and storage of raw materials and trees and stumps. This includes, but is not limited to, sawdust, shavings, bark, pulp, hog fuel, and log yard waste; but it does not include wood pieces or particles containing chemical preservatives such as creosote, pentachlorophenol, or copper-chrome-arsenate.

Laws and Regulations Affecting the Establishment and Operation of Urban Wood Waste Management Systems:

- No state law banning urban wood waste or yard waste disposal in MSW disposal facilities. 


\section{ILLINOIS}

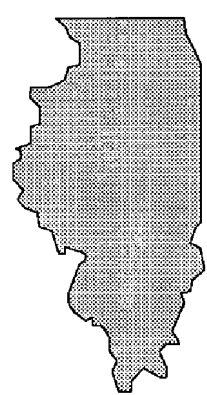

\section{State Definition of Urban Wood Waste}

- The State of Illinois defines urban wood waste as Landscape Waste.

Laws and Regulations Affecting the Establishment and Operation of Urban Wood Waste Management Systems:

- Environmental Protection Act PA-86-1430 bans disposal of landscape waste in solid waste disposal facilities as of July 1, 1990.

\section{INDIANA}

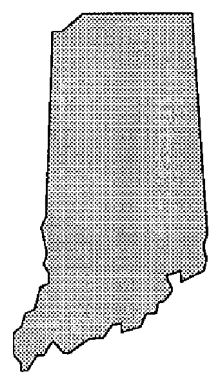

\section{State Definition of Urban Wood Waste}

- The State of Indiana defines urban wood waste under the definition of Vegetative Matter.

- Vegetative Matter means any yard or landscaping waste, including leaves, grass, brush, limbs, and branches resulting from commercial, industrial, and agricultural operations or from community activities.

Laws and Regulations Affecting the Establishment and Operation of Urban Wood Waste Management Systems:

- Vegetative Matter Ban (1c 13-7-29-3) bans disposal of vegetative matter in solid waste disposal facilities as of October 31, 1994.

- Vegetative matter must be source-separated.

\section{IOWA}

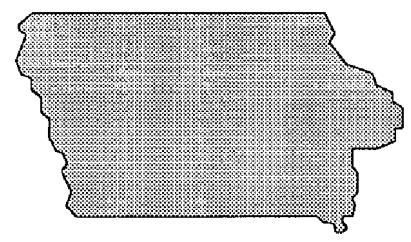

\section{State Definition of Urban Wood Waste}

- The State of Iowa defines urban wood waste under the definition of Yard Waste.

- Yard Waste debris such as grass clippings, leaves, garden waste, brush and trees; it does not include tree stumps.

- Trees means trunks, limbs, stumps, or branches from trees or shrubs and untreated, uncoated, chemically unchanged wood wastes. This shall not include wood products that are part of an otherwise defined waste or have been contaminated by coatings, treatments or metals. 
Laws and Regulations Affecting the Establishment and Operation of Urban Wood Waste Management Systems:

- HF 753 105.1(2) (January 1, 1991). Burial of yard waste at a sanitary landfill is prohibited. However, yard waste that was separated at its source from other solid waste may be accepted by a sanitary landfill for the purposes of soil conditioning or composting.

- Incineration of yard waste at a sanitary landfill is prohibited.

\section{KANSAS}

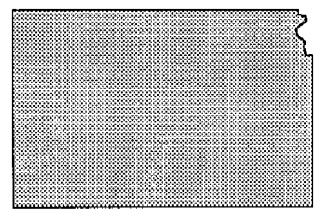

State Definition of Urban Wood Waste

- A definition of urban wood waste has not been obtained as of this time.

Laws and Regulations Affecting the Establishment and Operation of Urban Wood Waste Management Systems:

- HB 2801 Requires counties in Kansas to design a plan that schedules waste reduction goals. Composting and management of yard waste are to be part of this plan.

\section{KENTUCKY}

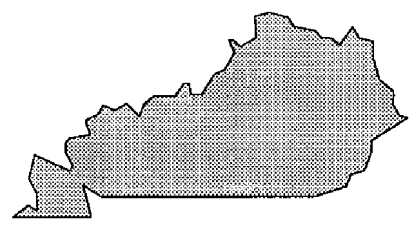

\section{State Definition of Urban Wood Waste}

- The State of Kentucky does not define urban wood waste under statute or rule, but generally includes urban wood waste under yard waste materials.

- Some urban wood waste is classified as Agricultural Waste, that is non-hazardous waste resulting from the production and processing of on-the-farm agricultural products, including manures, prunings and crop residues.

Laws and Regulations Affecting the Establishment and Operation of Urban Wood Waste Management Systems:

- No state law banning urban wood waste or yard waste disposal in MSW disposal facilities.

- Solid Waste Management Plans requires that counties have a plan for yard waste composting.

- Several sanitary landfills have imposed bans on disposal of yard waste in their facilities. 


\section{LOUISIANA}

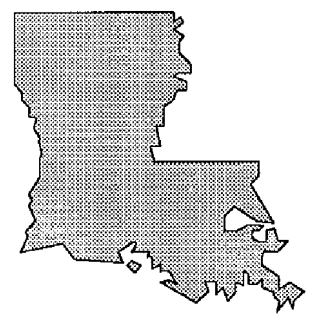

\section{State Definition of Urban Wood Waste}

- The State of Louisiana defines Wood Waste as types of waste typically generated by sawmills, plywood mills, and wood yards associated with the lumber and paper industry, such as wood residue, cut-offs, wood chips, sawdust, wood shavings, bark, wood refuse, and wood-fired boiler ash. Wood product materials such as treated lumber, glued plywood, and bonded materials are not considered urban wood waste under this definition.

Laws and Regulations Affecting the Establishment and Operation of Urban Wood Waste Management Systems:

- $\quad$ No state law banning urban wood waste or yard waste disposal in MSW disposal facilities. Wood waste is primarily disposed in Construction and Demolition Debris landfills.

\section{MAINE}

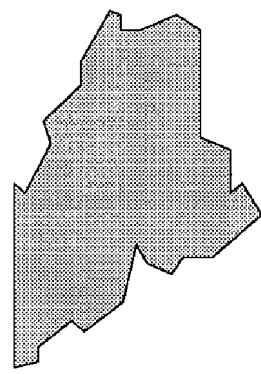

\section{State Definition of Urban Wood Waste}

- The State of Maine defines urban wood waste under the definition of Vegetative Waste and Wood Waste.

- Vegetative Waste means wastes consisting of plant matter from farms, homes, plant nurseries, and greenhouses. These shall include plant stalks, hulls, leaves, and tree waste processed through a wood chipper.

- Wood Waste means brush, stumps, lumber, bark, wood chips, shavings, waste. slabs, edgings, slash, and sawdust, that are not mixed with other solid or liquid

Laws and Regulations Affecting the Establishment and Operation of Urban Wood Waste Management Systems:

- No state law banning urban wood waste or yard waste disposal in MSW disposal facilities. 


\section{MARYLAND}

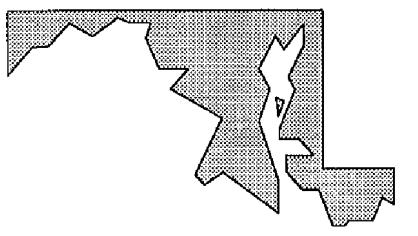

\section{State Definition of Urban Wood Waste}

- The Code of Maryland Regulations defines urban wood waste under the definition of Natural Wood Waste.

- Natural Wood Waste means free and other natural vegetative refuse. Natural Wood Waste includes tree stumps, brush and limbs, root mats, logs, unadulterated wood waste, and other natural vegetative materials.

Laws and Regulations Affecting the Establishment and Operation of Urban Wood Waste Management Systems:

- Environmental Article 9-1724 Source-separated yard waste banned from refuse disposal systems, unless the waste is to composted or mulched. Effective October 1992.

\section{MASSACHUSETTS}

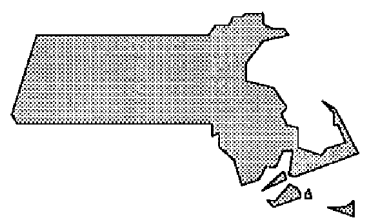

\section{State Definition of Urban Wood Waste}

- Massachusetts Department of Environmental Protection 310 CMR Section 16.02 definition for Wood Waste means discarded material consisting of trees, stumps and brush, including but not limited to sawdust, chips, shavings and bark. Wood waste does not include new or used lumber or wood from construction and demolition waste and does not include wood pieces or particles containing or likely to contain asbestos, or chemical preservatives such as creosote or pentachlorophenol, or paints, stains or other coatings.

- Yard Waste means deciduous and coniferous seasonal deposition (e.g., leaves) grass clippings, weeds, hedge clippings, garden material and brush.

Laws and Regulations Affecting the Establishment and Operation of Urban Wood Waste Management Systems:

- Statewide regulation banning yard waste disposal in MSW disposal facilities.

\section{MICHIGAN}

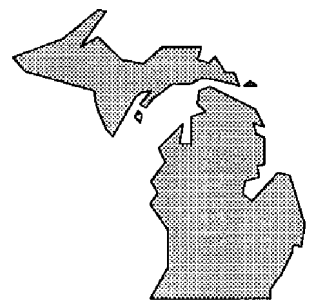

\section{State Definition of Urban Wood Waste}

- The State of Michigan defines urban wood waste under the definition of Yard Clippings.

- Yard Clippings are leaves, grass clippings, vegetable or other garden debris, shrubbery, or brush or tree trimmings less than four feet in length and two inches in diameter, that can be converted to compost humus. It does not include stumps, agricultural waste, animal waste, roots, sewage sludge, or garbage. 
Laws and Regulations Affecting the Establishment and Operation of Urban Wood Waste Management Systems:

- Solid Waste Management Act, 1978 PA 641, as amended (Act 641). PA267 Yard clippings partially banned from state and (MSW) disposal facilities by March 28, 1993. Statewide law banning yard waste disposal in (MSW) disposal facilities effective March 28, 1995.

\section{MINNESOTA}

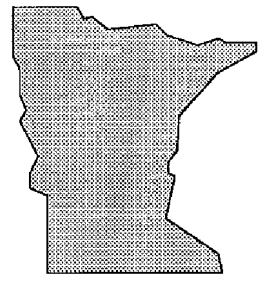

State Definition of Urban Wood Waste

- The State of Minnesota defines urban wood waste under the Waste Management Act definition of Yard Waste.

- Yard Waste means garden waste, leaves, lawn clippings, weeds, pruning, and shrub and tree waste generated from residential or commercial groundskeeping. Yard waste does not include waste from right-of-way clearing and grubbing, timber harvesting or processing waste, or construction projects unless the property includes existing residential or commercial structures. If structures exist on the property, then the cleared trees and shrubs are yard waste.

Laws and Regulations Affecting the Establishment and Operation of Urban Wood Waste Management Systems:

- Waste Management Act Amendments 1988. Minnesota Statute. 115A.931. Yard waste may not be disposed of in mixed (MSW), in a disposal facility, or in a resource recovery facility except for the purpose of composting or co-composting. Tree and shrub waste from right-of-way clearing and grubbing, or construction projects without existing residential or commercial structures can enter MPCA permitted or permit-byrule demolition land disposal facilities or be burned, with a permit from Department of Natural Resources.

\section{MISSISSIPPI}

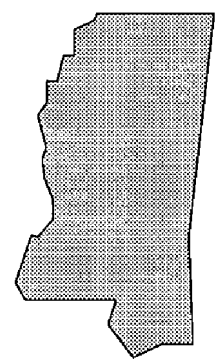

State Definition of Urban Wood Waste

- The State of Mississippi defines urban wood waste under the definition of Yard Waste.

- Yard Waste means the leaves, grass cuttings, weeds, garden waste, tree limbs, and other vegetative waste generated at residential, commercial, institutional, governmental, or industrial properties.

Laws and Regulations Affecting the Establishment and Operation of Urban Wood Waste Management Systems:

- 115A.931 Yard waste banned from disposal in (MSW) disposal facilities effective January 1992. 


\section{MISSOURI}

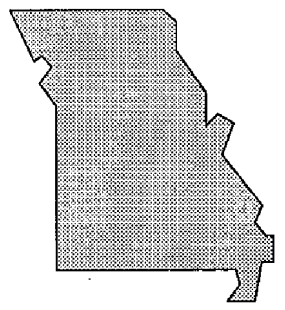

\section{State Definition of Urban Wood Waste}

- The State of Missouri defines urban wood waste under the definition of Yard Waste.

Yard Waste means leaves, grass clippings, yard and garden vegetation and Christmas trees. The term does not include stumps, roots or shrubs with intact root balls. The MDNR interprets the definition of "yard and garden vegetation" to include shrubs, vegetable and flower garden waste and brush and trees produced as a result of yard and garden care and maintenance. Yard waste includes plant waste produced by plant nurseries, greenhouses and similar operations that grow or produce plants, trees, flowers or shrubs. Yard waste also includes the plant waste generated or collected by private, public or commercial lawn care, landscaping, tree-trimming and plantcare services. Excluded are tree trunks or limbs that have a diameter greater than six (6) inches.

Laws and Regulations Affecting the Establishment and Operation of Urban Wood Waste Management Systems:

- SB 530 (1990) incorporated into Missouri Solid Waste Law is designed to encourage county cooperation and local responsibility in order to achieve a $40 \%$ reduction in amount of solid waste disposed in Missouri landfills by the year 1998. Since yard waste constitutes approximately $18-20 \%$ of the volume of solid waste generated and possible destined for landfilling, it is prohibited from being disposed in Missouri landfills after January 1, 1992.

\section{MONTANA}

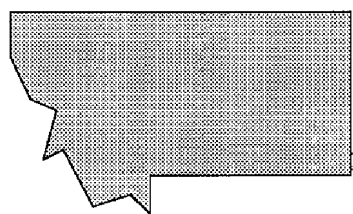

\section{State Definition of Urban Wood Waste}

- The State of Montana defines urban wood waste under the Administrative Rules of Montana (ARM) 16.14.503(1)(b) definition of Inert Waste. "Group III waste includes wood wastes and non-water soluble solids. Examples include, but not limited to, the following:

(ii) wood materials, brush, lumber, and vehicle tires; and

(iii) industrial mineral wastes...."

Laws and Regulations Affecting the Establishment and Operation of Urban Wood Waste Management Systems:

- No state law banning urban wood waste or yard waste disposal in MSW disposal facilities.

- Disposal of wood waste (inert waste) must occur at licensed Class III landfills unless utilized toward beneficial use. 


\section{NEBRASKA}

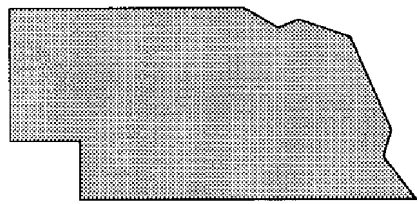

State Definition of Urban Wood Waste

- The State of Nebraska defines urban wood waste under Title 132Integrated Solid Waste Management Regulations (September 8, 1993) definition of Yard Waste.

- Yard Waste shall mean accumulations of grass or shrubbery cuttings, leaves, and other organic materials collected as a result of the care of lawns, shrubbery, vines, and gardens.

Laws and Regulations Affecting the Establishment and Operation of Urban Wood Waste Management Systems:

- LB 127 (September 1994) Landfill ban on yard waste. Source-separated yard waste accepted by landfills for composting and soil conditions.

NEVADA

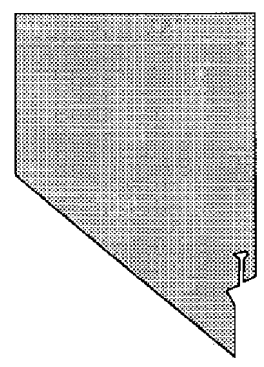

State Definition of Urban Wood Waste

- The State of Nevada defines urban wood waste under the definition of Inert Waste. An inert waste is unlikely to create an environmental hazard or threaten the health of the general public.

Laws and Regulations Affecting the Establishment and Operation of Urban Wood Waste Management Systems:

- No state law banning urban wood waste or yard waste disposal in MSW disposal facilities.

- Nevada Admin. Code 444.731 regulates wood waste indirectly through Class III industrial landfills.

- Due to arid conditions and the rural nature of the state, less than ten percent (10\%) of waste is composed of yard waste.

\section{NEW HAMPSHIRE}

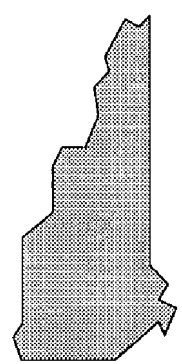

\section{State Definition of Urban Wood Waste}

- The State of New Hampshire defines urban wood waste under the definition of Yard Waste.

- Yard Waste means leaves, grass clippings, garden debris, and small or chipped branches. 
Laws and Regulations Affecting the Establishment and Operation of Urban Wood Waste Management Systems:

- Revised Statutes Annotated Chapter. 149-M:22, VII. Statewide law banning yard waste from solid waste disposal facilities and incinerators effective July 1993.

\section{NEW JERSEY}

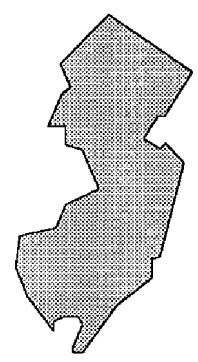

\section{State Definition of Urban Wood Waste}

- The State of New Jersey defines urban wood waste under the definition of Brush.

- Brush means branches, woody plants, and other like vegetative material. Leaves and grass do not constitute brush.

- NJAC 7:26 A-1.3 Class B Recyclable Material is a source-separated recyclable material that is subject to Department approval prior to receipt, storage, processing or transfer at a recycling center. Source-separated materials include whole trees, tree trunks, tree parts, brush, and leaves provided that they are not composted.

Laws and Regulations Affecting the Establishment and Operation of Urban Wood Waste Management Systems:

- No state law banning urban wood waste or yard waste disposal in MSW disposal facilities.

- PL 1987, C.102. Leaves banned from disposal in solid waste disposal facilities effective September 1988.

- Many municipalities have initiated self-imposed bans of yard and wood waste from solid waste disposal facilities.

\section{NEW MEXICO}

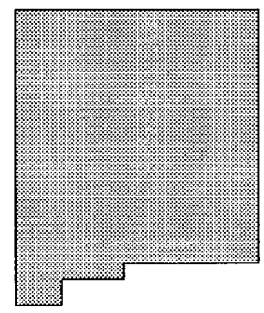

State Definition of Urban Wood Waste

- The State of New Mexico defines urban wood waste under the definition of Yard Refuse.

- Yard Refuse means vegetative matter resulting from landscaping, land maintenance and, land clearing activities.

Laws and Regulations Affecting the Establishment and Operation of Urban Wood Waste Management Systems:

- No state law banning urban wood waste or yard waste disposal in MSW'disposal facilities. 


\section{NEW YORK}

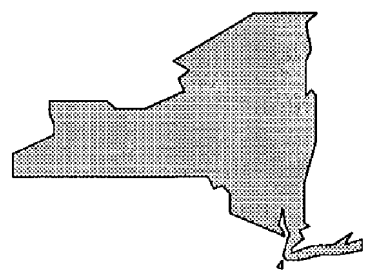

State Definition of Urban Wood Waste

- The State of New York defines urban wood waste under 6 NYCRR Part 360 - Solid Waste Management Facilities definitions of Land Clearing Debris, Yard Waste, and Construction and Demolition Debris.

Laws and Regulations Affecting the Establishment and Operation of Urban Wood Waste Management Systems:

- No state law banning urban wood waste or yard waste disposal in MSW disposal facilities.

- Composting and yard waste bans from (MSW) landfills are more popular in the eastern portion of the state where landfill tip fees are higher.

\section{NORTH CAROLINA}

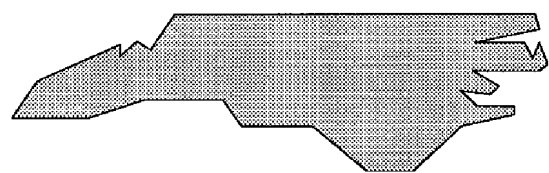

\section{State Definition of Urban Wood Waste}

- The State of North Carolina defines urban wood waste under three categories.

- Yard Waste means Yard Trash and Land Clearing

Waste. Yard Waste includes stumps, limbs, leaves, grass, and untreated wood; it also includes land clearing wastes and yard trash.

- Land Clearing Waste includes stumps, trees, limbs, brush, grass, and other naturally occurring vegetative material; it is solid waste generated solely from land clearing activities.

- Yard Trash includes brush, grass, tree limbs, and similar vegetative material; it is solid waste generated from landscaping and yard maintenance.

Laws and Regulations Affecting the Establishment and Operation of Urban Wood Waste Management Systems:

- North Carolina SWM Rules 15A NCAC 13 B (January 1992) As of January 1, 1993, disposal of yard trash is prohibited in a sanitary landfill; however, yard trash that has been separated may be accepted at a sanitary landfill where the facility provides and maintains a separate yard waste composting area.

\section{NORTH DAKOTA}

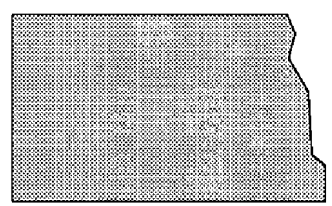

State Definition of Urban Wood Waste

- The State of North Dakota defines urban wood waste under the definition of Inert Waste material. 
Laws and Regulations Affecting the Establishment and Operation of Urban Wood Waste Management Systems:

- No state law banning urban wood waste or yard waste disposal in MSW disposal facilities.

- Wood wastes have not been targeted as a serious problem.

\section{OHIO}

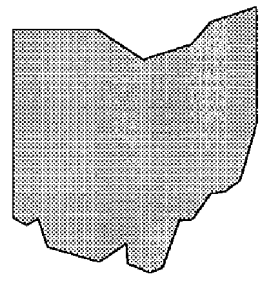

State Definition of Urban Wood Waste

- The State of Ohio defines urban wood waste under the definition of Yard Waste.

- Yard Waste is solid waste that includes only leaves, grass clippings, brush, garden waste, tree trunks, holiday trees, tree trimmings, and prunings from trees or shrubs.

Laws and Regulations Affecting the Establishment and Operation of Urban Wood Waste Management Systems:

- HB 592 Statewide law banning the disposal of yard waste in (MSW) disposal facilities and incinerators; however, disposal is permitted if yard waste is commingled with (MSW).

\section{OKLAHOMA}

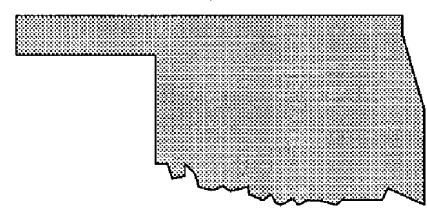

\section{State Definition of Urban Wood Waste}

- A definition of urban wood waste has not been obtained as of this time.

Laws and Regulations Affecting the Establishment and Operation of Urban Wood Waste Management Systems:

- No state law banning urban wood waste or yard waste disposal in MSW disposal facilities. 


\section{OREGON}

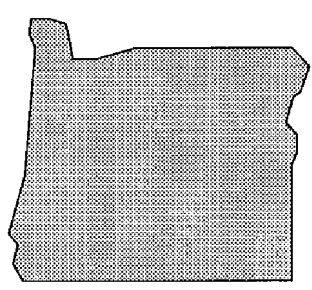

\section{State Definition of Urban Wood Waste}

- No statute or rule defines urban wood waste. Urban wood waste often refers to material left from logging operations.

Laws and Regulations Affecting the Establishment and Operation of Urban Wood Waste Management Systems:

- No state law banning urban wood waste or yard waste disposal in MSW disposal facilities.

- SB 66. Yard waste should be composted and collected.

\section{PENNSYLVANIA}

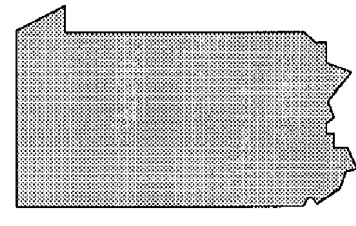

\section{State Definition of Urban Wood Waste}

- The State of Pennsylvania defines urban wood waste under the definitions of Yard Waste and Leaf Waste.

- Yard Waste includes leaves, grass clippings, garden residue, tree trimmings, chipped shrubbery, and other vegetative material.

- Leaf Waste are leaves, garden residues, shrubbery, and tree trimmings, and similar material, but not including grass clippings.

Laws and Regulations Affecting the Establishment and Operation of Urban Wood Waste Management Systems:

- $\quad 101$ 273.201. Loads composed primarily of leaf waste may not be disposed of at solid waste facilities effective September 26, 1990.

\section{RHODE ISLAND}

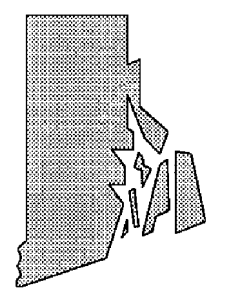

State Definition of Urban Wood Waste

- No statute or rule defines urban wood waste.

Laws and Regulations Affecting the Establishment and Operation of Urban Wood Waste Management Systems:

- No state law banning urban wood waste or yard waste disposal in MSW disposal facilities. 


\section{SOUTH CAROLINA}

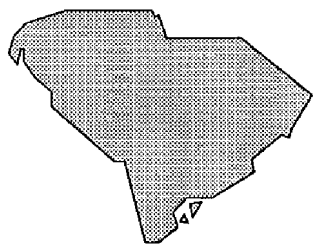

State Definition of Urban Wood Waste

- A definition of urban wood waste has not been obtained as of this time.

Laws and Regulations Affecting the Establishment and Operation of Urban Wood Waste Management Systems:

- Solid Waste Policy and Management Act of 1991 Effective May 27, 1993, yard waste banned from solid waste disposal facilities unless it is to composted. Yard waste must be source-separated. All solid waste disposal facilities required to have a separate composting area.

\section{SOUTH DAKOTA}

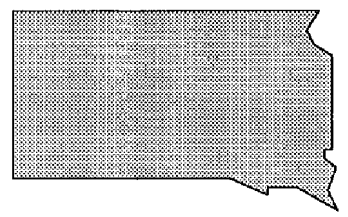

\section{State Definition of Urban Wood Waste}

- No specific statute or rule defines urban wood waste. Generally, this material is included under the definition of Yard Waste.

- Yard Waste are leaves, grass clippings and other similar waste vegetative material.

Laws and Regulations Affecting the Establishment and Operation of Urban Wood Waste Management Systems:

- Second Century Environmental Protection Act (January 1, 1995) Statewide law banning the disposal of yard waste in (MSW) disposal facilities to be phased in from January 1,1995 to July 1997.

\section{TENNESSEE}

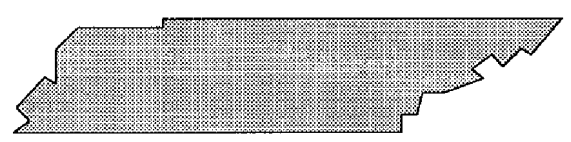

\section{State Definition of Urban Wood Waste}

- A definition of urban wood waste has not been obtained as of this time.

Laws and Regulations Affecting the Establishment and Operation of Urban Wood Waste Management Systems:

- No state law banning urban wood waste or yard waste disposal in MSW disposal facilities.

- Some municipalities ban the disposal of yard waste in solid waste disposal facilities on a voluntary basis. 


\section{TEXAS}

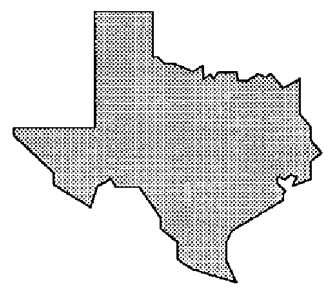

State Definition of Urban Wood Waste

- The State of Texas defines urban wood waste under the definition of Yard Waste.

- Yard Waste means leaves, grass clippings, yard and garden debris, and brush, including clean woody vegetative material not greater than six (6) inches in diameter, that results from landscape maintenance and land clearing operations. Does not include stumps, roots or shrubs with intact root balls.

Laws and Regulations Affecting the Establishment and Operation of Urban Wood Waste Management Systems:

- SB 1340. An act relating to recycling programs, establish a goal to recycle forty percent $(40 \%)$ of the total waste stream by January 1,1994 .

\section{UTAH}

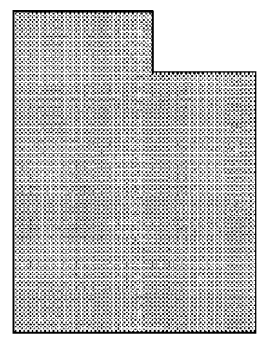

State Definition of Urban Wood Waste

- The State of Utah defines urban wood waste under the definition of Yard Waste.

- Yard Waste means vegetative matter resulting from landscaping, land maintenance, and land clearing operations; it includes grass clippings, prunings, and other discarded material generated from yards, gardens, parks, and similar types of facilities.

Laws and Regulations Affecting the Establishment and Operation of Urban Wood Waste Management Systems:

- No state law banning urban wood waste or yard waste disposal in MSW disposal facilities.

- In Utah, yard waste is regulated as simply a solid waste that may be disposed in all Classes of landfills (Class I-V).

- Several counties have indicated plans for banning the disposal of yard waste in (MSW) landfills. 


\section{VERMONT}

\section{State Definition of Urban Wood Waste}

- The State of Vermont defines urban wood waste under the definition of Solid Waste.

Laws and Regulations Affecting the Establishment and Operation of Urban Wood Waste Management Systems:

- No state law banning urban wood waste or yard waste disposal in MSW disposal facilities.

- Due to small towns and low generation rates of yard waste, equipment cannot be purchased.

\section{VIRGINIA}

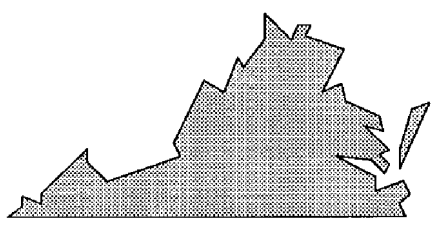

\section{State Definition of Urban Wood Waste}

- The State of Virginia regulations do not list a specific definition for urban wood waste; however, regulations exclude wood waste burned for energy from being defined as solid waste.

Laws and Regulations Affecting the Establishment and Operation of Urban Wood Waste Management Systems:

- No state law banning urban wood waste or yard waste disposal in MSW disposal facilities.

- HB 198 Any county, city, or town may ban leaves or grass clippings from solid waste disposal facilities.

\section{WASHINGTON}

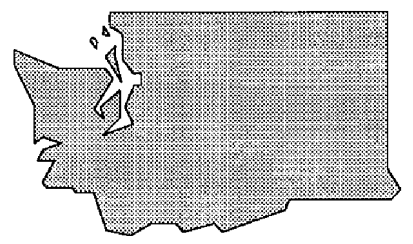

\section{State Definition of Urban Wood Waste}

- The State of Washington defines urban wood waste under the definition of Wood Waste and Yard Debris.

- Wood Waste is solid waste consisting of wood pieces or particles generated as a by-product or waste from the manufacturing of wood products, handling and storage of raw materials and trees and stumps.

This includes, but is not limited to, untreated manufacturing wood, used wooden pallets and grates, post-consumer wood wastes, sawdust,, chips, shavings, bark, hog fuel, and logs.

- Yard Debris is vegetative matter resulting from landscaping maintenance or land clearing operations, and includes materials such as tree and shrub trimmings, grass clippings, weeds, trees, and tree stumps. 
Laws and Regulations Affecting the Establishment and Operation of Urban Wood Waste Management Systems:

- No state law banning urban wood waste or yard waste disposal in MSW disposal facilities.

\section{WEST VIRGINIA}

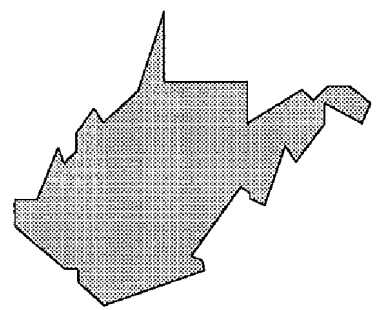

State Definition of Urban Wood Waste

- A definition of urban wood waste has not been obtained as of this time.

Laws and Regulations Affecting the Establishment and Operation of Urban Wood Waste Management Systems:

- Statewide law banning the disposal of yard waste in (MSW) disposal facilities.

\section{WISCONSIN}

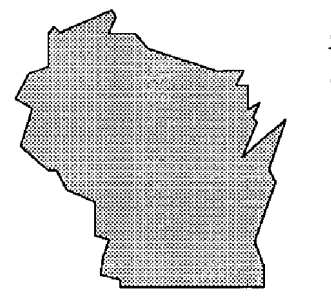

State Definition of Urban Wood Waste

- Urban wood waste is defined as unpainted, untreated wood, clean wood, brush, stumps, or trees.

Laws and Regulations Affecting the Establishment and Operation of Urban Wood Waste Management Systems:

- Wisconsin Act 335 "The Recycling Law". Statewide law banning the disposal of yard waste in (MSW) disposal facilities effective January 1993.

\section{WYOMING}

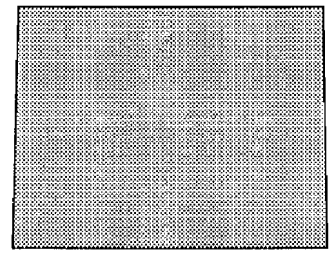

\section{State Definition of Urban Wood Waste}

- The State of Wyoming defines urban wood waste under the Solid Waste Management Rules and Regulations (Amended) definition of Clean Wood.

- Clean Wood means untreated wood that has not been painted, stained, or sealed. Clean wood does not include treated railroad ties, treated posts, paper, or construction/demolition wastes containing non-wood materials.

Laws and Regulations Affecting the Establishment and Operation of Urban Wood Waste Management Systems: 
NREL AAE-4-14077-01

- No state law banning urban wood waste or yard waste disposal in MSW disposal facilities. 


\section{The Effect of Legislative and Policy Initiatives}

\section{Current Opportunities and Constraints to Establishing or Maintaining Effective Management Programs}

In addition to looking at state solid waste regulatory programs, solid waste management professionals were consulted. The purpose was to gather insights into how legislative and policy initiatives affected the ability to manage urban wood wastes. Two hundred-thirteen people participated; 170 indicated that they engaged in some form of urban wood waste management. Table III-1 indicates the number engaged in local government units (LGU) and privately managed systems.

Table III-1. Management Structure of Wood Waste Assessment Respondents

\begin{tabular}{||l|r||}
\hline \multicolumn{1}{|c|}{ Management Structure } & \multicolumn{1}{|c|}{$\begin{array}{l}\text { Number of } \\
\text { Facilities }\end{array}$} \\
\hline $\begin{array}{l}\text { Local Government Units } \\
\text { (LGUs) }\end{array}$ & 159 \\
\hline Privately Managed & 11 \\
\hline Total & 170 \\
\hline
\end{tabular}

\section{Opportunities}

The principal incentive for establishing and operating a wood waste management system was the expansion of state laws and regulations prohibiting the disposal of urban wood waste in (MSW) disposal facilities. Laws and regulations have created a demand for urban wood waste management services. Because of state requirements of LGUs to plan for and see to the management of (MSW)s, LGUs are the institutions that are establishing urban wood waste management systems. These systems include mulching, composting, land application, and combustion. Opportunities to provide urban wood waste management services through contracts with many local governments have increased because of increased LGU initiatives. Subsequently, new markets have developed, or expanded, to address old and new uses of end products. Markets are one of the most important factors in the successful operation of an urban wood waste management system.

Results indicate that urban wood waste management systems are frequently grouped with yard waste management systems for regulation and permitting. Technologies and practices for the management of urban wood wastes are more varied than for yard waste.

\section{Constraints}

Table III-2 summarizes the primary constraints that are inhibiting the establishment and operation of urban wood waste management systems. Economics, meaning the costs involved in the 
operation and maintenance of an urban wood waste management system, were identified by 59 $(57.8 \%)$ as the primary constraint to effectively managing urban wood wastes. The economic factors identified as affecting urban wood waste management included operation and maintenance costs, economies-of-scale, funding, start-up costs, collection fees, equipment costs, cost of debagging, source separation of materials, and end-markets for products. The economic factors identified can cause the overall cost of the operation to increase and in some cases result in a decreased value of end products. Decreased profit occurred in some organizations operating at the break-even threshold and closure of their wood waste management systems was a distinct possibility.

The second leading constraint, cited by $33(32.4 \%)$, was a combination of the regulatory and permitting requirements by various levels of government. Urban wood waste management systems increasingly are subject to laws, regulations and permitting requirements. There is difficulty with permitting or regulating an urban wood waste management facility due to inconsistent or deficient definitions for this relatively new, emerging solid waste management system. Many jurisdictions permit and regulate wood waste either as yard waste, usually including grass and leaves, or as a (MSW). Both solid waste streams are incompatible with urban wood waste management technologies and practices. Urban wood waste management systems are frequently grouped with yard waste (grass and leaves) management systems for regulations and permitting. Technologies and practices for the management of urban wood wastes, however, are more varied than for yard waste. This difference is not normally recognized in the regulatory and permitting process, resulting in longer and more time consuming consideration of permit applications.

The last major category of constraints cited by ten $(9.8 \%)$ was issues relating to community relations. This included public resistance to facility siting and operation, due largely to inadequate public education; contamination of incoming or outgoing materials; and odor complaints.

Problems involving community relations are generally perceived as particularly contentious. However, problems involving the public, or the public's perception of urban wood waste management systems, rank rather low on the hierarchy of constraints relative to economic factors and regulatory and permitting issues. 
Table III-2. Constraints to Wood Waste Management

\begin{tabular}{||l|c||}
\hline \multicolumn{1}{|c|}{ Constraints } & Number of Responses \\
\hline Economic Factors & \\
\hline Costs (overall) & 16 \\
\hline Insufficient End Markets & 9 \\
\hline Material and Source Separation & 7 \\
\hline Operation and Maintenance & 7 \\
\hline Funding & 5 \\
\hline Equipment Costs & 3 \\
\hline Equipment Capacity & 3 \\
\hline Debagging & 3 \\
\hline Start-up Cost & 2 \\
\hline Capacity & 2 \\
\hline Collection Cost/Fees & 2 \\
\hline Total & $\mathbf{5 9}$ \\
\hline Regulations and Permitting & \\
\hline Permitting & 15 \\
\hline Regulations & 14 \\
\hline Zoning & 2 \\
\hline Policy & 2 \\
\hline Total & $\mathbf{3 3}$ \\
\hline Public Relations & \\
\hline Public Resistance & $\mathbf{5}$ \\
\hline Contamination & 3 \\
\hline Odor Complaints & 2 \\
\hline Total & $\mathbf{1 0}$ \\
\hline GRA IND TOTAL & $102^{\mathbf{2}}$ \\
\hline Note: Tolequal & \\
\hline
\end{tabular}

Note: Total equals 102 rather than 170 due to responses indicating "no constraints" or to no response. 


\section{How State Initiatives Affect the Generator's Ability to Find Management Solutions}

It was determined that $54 \%$ of participants feel state regulations have not affected their current management methods. Twenty-three percent believed that state regulations have affected management methods, $17 \%$ gave a response of "other", and the remaining six percent gave multiple answers. Some of the multiple answer and "other" responses indicated that methods did not change, but distance traveled for disposal or disposal fees increased. These responses also showed that increasing regulation caused some companies to develop their own management and storage facilities.

Approximately 58\% stated the management or disposal of urban wood waste was regulated in their state, $34 \%$ believed that no state regulations were in place, and the remaining eight percent were unsure of state regulations. Different opinions on the presence or absence of state regulations were occasionally observed in the same states. These contradictions may be attributed to an organization being aware only of urban wood waste regulations that affect it's own operation.

Of the 121 participants from states where urban wood waste is regulated, 54\% felt their disposal options have decreased (Figure III-1). Twenty-seven percent felt their options have remained constant, and $19 \%$ believe that disposal options have actually increased due to implementation of state regulations. These figures give an idea of current trends caused by state regulation but do not support any conclusions on a national level.

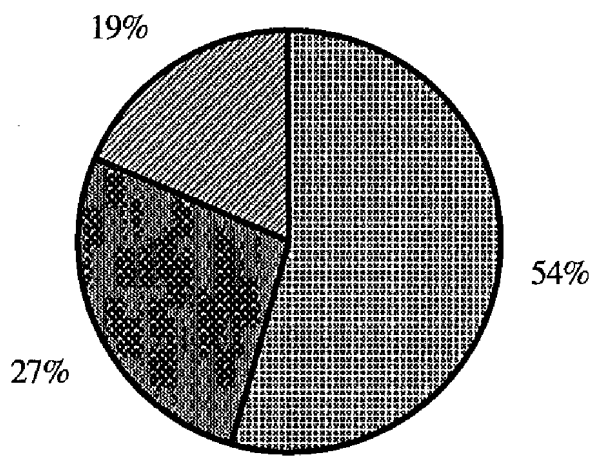

国 Decrease in disposal options $54.2 \%$

No change in disposal options $27.1 \%$

Increase in disposal options $18.6 \%$

Figure III-1. Effects of state regulation on urban wood waste disposal options

\section{Current and Future Directions on the Regulation of Urban Wood Waste Management}

It seems likely that the regulation of urban wood waste at the state and local levels will continue to expand. The number of states that require urban wood waste to be managed in a manner other 
than landfilling or open burning undoubtedly will increase. With more than half of the states in this country implementing such controls within the past 10 years, the trend is clearly upward. This conclusion is based primarily on two factors. The first is that regulation of urban wood waste in many states has the same kind of support as recycling which is currently very popular. The other critical factor is the goal to preserve existing landfill capacity. States have implemented urban wood waste regulation to extend the life of existing landfills (Glenn, 1990). These capacity pressures are expected to continue, driving more states and municipalities to limit disposal options for urban wood waste management.

Currently, there are few regulations designed for permitting of urban wood waste management facilities; there will be regulations in the future. This will cause problems at the LGU level because local regulators will be hesitant to permit a facility that does not fit neatly within current permit categories. It may be that, with the increasing number of urban wood waste management facilities, state governments will be spurred to come up with more appropriate, tailored permitting processes. 


\section{Assessment of the Quantity and Character of Urban Wood Waste}

\section{Generation of Urban Wood Waste}

A recent ISA Research Trust study conducted by NEOS Corporation (1994) for ISA conservatively estimated that 200 million cubic yards of urban wood waste are generated in the United States each year. This estimate is considered conservative due to the absence of orchard and nursery wood waste generation data. This estimate also does not take into consideration residential yard waste collection (i.e. curbside collection, drop-off facilities). The investigators, however, believe that some minimal residential yard waste quantities are included in the estimated 200 million cubic yards. Because of the way in which urban wood wastes, yard wastes, and leaves are managed, it is impossible to completely separate each solid waste stream.

\section{Quantities of Urban Wood Waste}

The ISA Research Trust Study concluded that lawn, garden, and landscape companies generate only a small amount of urban wood wastes. On the aggregate however, the total annual amount of urban wood waste generated by these companies was approximately 74 million cubic yards (see Table IV-1), or about $37 \%$ of the national total (see Figure IV-1). This may be attributed to the large number of lawn, garden, and landscape companies in the United States. Commercial tree care organizations also produce approximately 73 million cubic yards ( $37 \%$ of the national total) per year. Consequently the amount of urban wood waste generated by lawn, garden, landscape, and commercial tree companies represents $75 \%$ of all urban wood waste generated yearly in the United States (NEOS Corporation, 1994).

Table IV-1. National Estimate of Urban Wood Waste Generation (Cubic Yards per Year)

\begin{tabular}{||l|r|r|r|r|r|r||}
\hline \multicolumn{1}{|c|}{ Generator Group } & $\begin{array}{c}\text { Overall } \\
\text { Population } \\
\text { (N) }\end{array}$ & \multicolumn{1}{c|}{$\begin{array}{c}\text { Sample } \\
\text { Mean }\end{array}$} & \multicolumn{1}{c|}{$\begin{array}{c}\text { Bound On } \\
\text { Mean }\end{array}$} & $\begin{array}{c}\text { Residue } \\
\text { Production } \\
\text { (000s) }\end{array}$ & $\begin{array}{c}\text { Bound On } \\
\text { Generator } \\
\text { (000s) }\end{array}$ & $\begin{array}{c}\text { \% } \\
\text { Error }\end{array}$ \\
\hline Commercial Tree Care & 10,414 & 7,004 & 3,177 & 72,937 & 27,137 & 37 \\
\hline Utilities & 1,916 & 4,872 & 661 & 9,334 & 841 & 9 \\
\hline Municipalities & 2,662 & 5,883 & 2,041 & 15,527 & 5,375 & 35 \\
\hline Parks \& Rec. Depts. & 4,460 & 5,018 & 4,117 & 22,382 & 8,171 & 37 \\
\hline $\begin{array}{l}\text { Land Clearance } \\
\text { Contractors }\end{array}$ & 1,316 & 4,229 & 4,662 & 5,565 & 2,325 & 42 \\
\hline Lawn/Garden/Landscapers & 35,100 & 2,130 & 330 & 74,780 & 11,570 & 15 \\
\hline Total Mean & $\mathbf{5 5 , 8 6 8}$ & $\mathbf{3 , 5 8 8}$ & 744 & $\mathbf{2 0 0 , 5 2 5}$ & $\mathbf{3 1 , 1 7 8}$ & $\mathbf{1 6 \%}$ \\
\hline
\end{tabular}

Source: NEOS Corporation, 1994. 


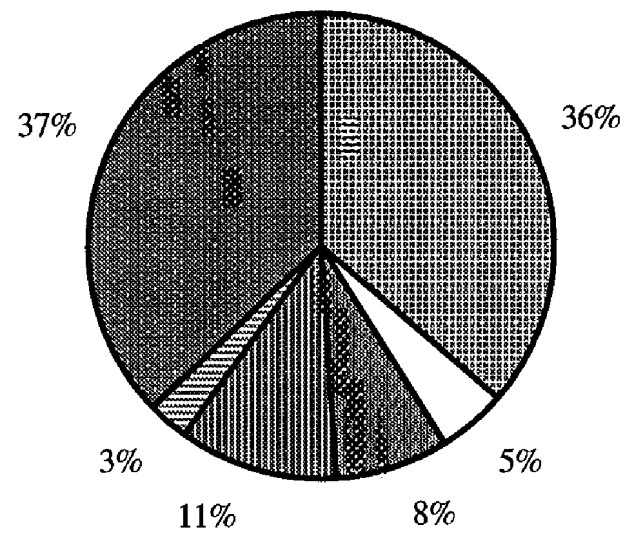

国 Comm. Tree Care (36\%)

$\square$ Utilities (5\%)

Municipalities (8\%)

专 Parks \& Rec. Depts. (11\%)

目Land Clearance Contractors (3\%)

Dawn/Garden/Landscapers (37\%)

Figure IV-1. Percent urban wood waste generation by facility Generated from Table IV-1

The study also documented the fact that the generation of urban wood wastes varies seasonally (see Figure IV-2). The study concluded that the highest percent of urban wood waste is created in the summer $(30 \%)$ followed closely by fall $(28 \%)$, then spring $(23 \%)$ and finally winter $(19 \%)$ (NEOS Corporation, 1994).
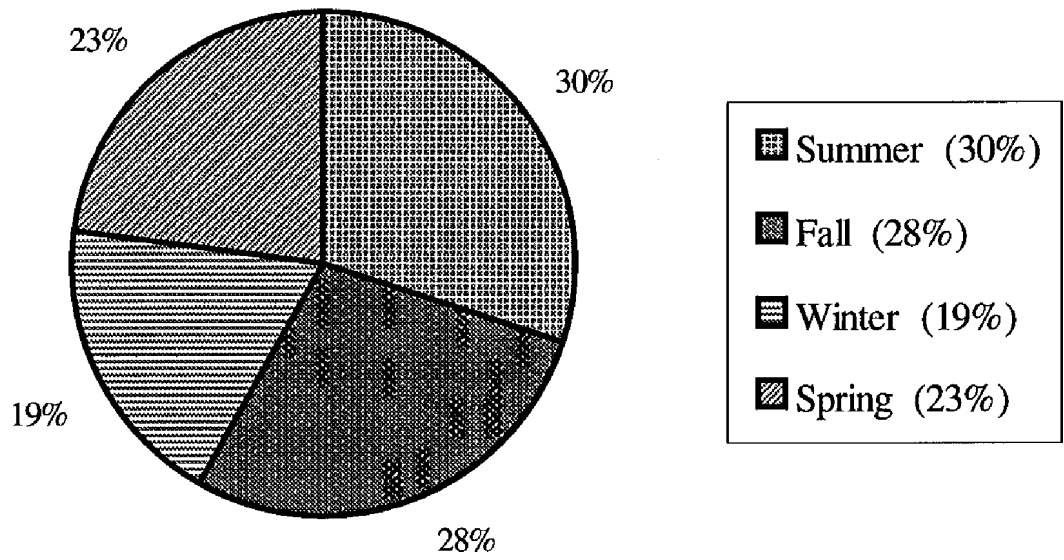

Figure IV-2. Seasonal contributions to total urban wood waste generation Source: NEOS Corporation, 1994. 


\section{Types of Urban Wood Waste Generated}

Sixty-seven percent of all urban wood waste generated in the United States annually is in the form of chips (134 million cubic yards per year) (Table IV-2, National Estimate of Urban Wood Waste Generation by Type). The second most common type of urban wood waste is unchipped logs that contributes about $15 \%$ to the annual total (see Figure IV-3). Leaves and grass clippings contribute about two percent each to the annual generation of urban wood waste. These figures, however, may actually be higher if collected residential yard wastes are taken into consideration (NEOS Corporation, 1994).

Table IV-2. National Estimate of Urban Wood Waste Generation by Type (1000 Cubic Yards per Year)

\begin{tabular}{|l|r|}
\hline \multicolumn{1}{|c|}{ Residue From } & \multicolumn{1}{c|}{ Quantity (000s) } \\
\hline Chips & 134,352 \\
\hline Unchipped Logs & 30,078 \\
\hline Unchipped Tops and Brush & 16,042 \\
\hline Unchipped Mixed Wood & 10,026 \\
\hline Fall Leaves & 4,010 \\
\hline Grass Clippings & 4,010 \\
\hline Whole Stumps & 2,005 \\
\hline Total & $\mathbf{2 0 0 , 5 2 5}$ \\
\hline \hline
\end{tabular}

Source: NEOS Corporation, 1994.

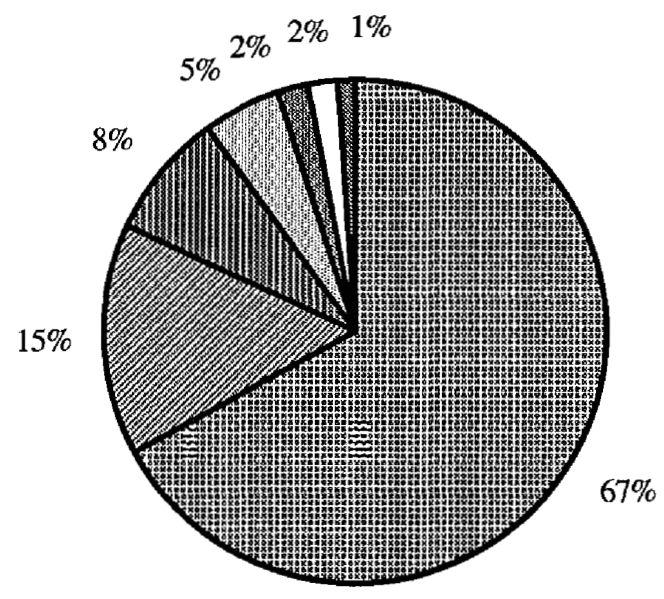

Unchipped Logs (15\%)
Unips (67\%)
Unchipped Tops and Brush (8\%)
Unchipped Mixed Wood (5\%)
Gall Leaf Collection (2\%)
Grass Clippings (2\%)
Whole Stumps (1\%)

Figure IV-3. National estimate of urban wood waste formation by type Generated from Table IV-2 


\section{Trends In Urban Wood Waste Generation}

Fifty percent of the respondents in the ISA Research Trust Study concluded that urban wood waste quantities had increased. Forty-two percent indicated that quantities had stayed approximately the same. Fifty-six percent of the respondents felt that urban wood waste quantities would increase while $36 \%$ felt they would remain constant. For both questions, seven percent responded that quantities have decreased or will decrease in the future (NEOS Corporation, 1994). 


\section{Assessment of Current Urban Wood Waste Management Practices}

\section{Methods of Urban Wood Waste Management}

Due to changing legislation, the traditional methods for urban wood waste management are changing. Currently 30 states have, or will soon be enacting, legislation regulating the management of urban wood waste. The predominant thrust of the legislation will be the banning of landfilling of urban wood waste. This will result in organizations having to develop or find alternative methods to landfilling.

\section{Current Urban Wood Waste Management Methods}

The ISA Research Trust study of urban wood waste management practices in the United States found that about $17 \%$ of all urban wood waste is being the landfilled (Figure V-1); the majority (43\%) is given away. In addition to the $43 \%$ that is being given away, $12 \%$ is sold, and another $11 \%$ is left on-site. The remaining urban wood waste management methods are divided into various categories, including a category for "Other." It is interesting to note that the study recorded such methods as mixing with sewage, midnight dumping, and land leveling as management methods in the "Other" category (NEOS Corporation, 1994).

Table V-1. Estimate of Urban Wood Waste Management Methods in the United States (Thousand Cubic Yards per Year)

\begin{tabular}{||l|r||}
\hline \multicolumn{1}{|c|}{ Disposal Method } & \multicolumn{1}{c|}{ Quantity } \\
\hline Given Away & 84,220 \\
\hline Landfilled & 34,088 \\
\hline Sold & 24,063 \\
As Boiler Fuel & 4,010 \\
As Compost & 2,005 \\
As Mulch & 10,026 \\
As Wood Products & 1,805 \\
As Firewood & 6,016 \\
Other & 200 \\
\hline Left On-site & 22,058 \\
\hline Sent to Recycling Center & 12,031 \\
\hline Burnt for Energy & 6,016 \\
\hline Stock Piled/Used On-site & 8,021 \\
\hline Incinerated & 602 \\
\hline Other & 6,016 \\
\hline Total & 197,116 \\
\hline \hline
\end{tabular}

Source: NEOS Corporation, 1994. 
The total given in Table V -1 does not match the total given as the national estimate of annual urban wood waste generation because of incomplete information.

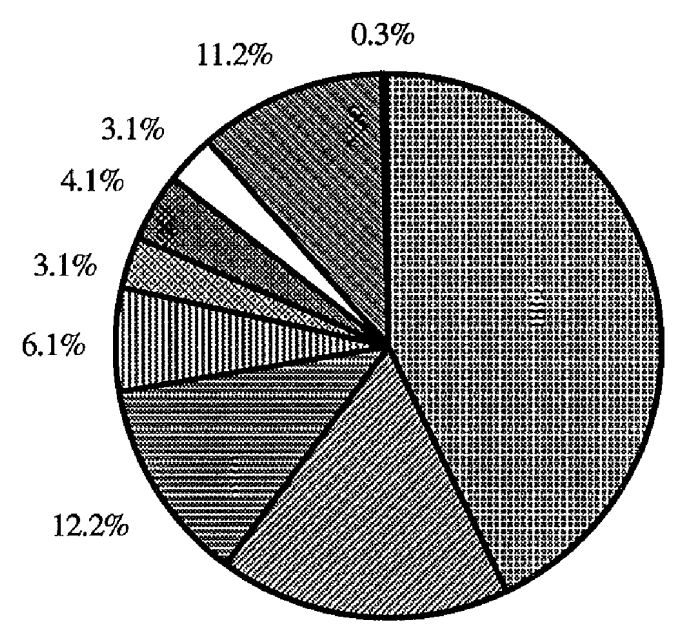

$17.3 \%$

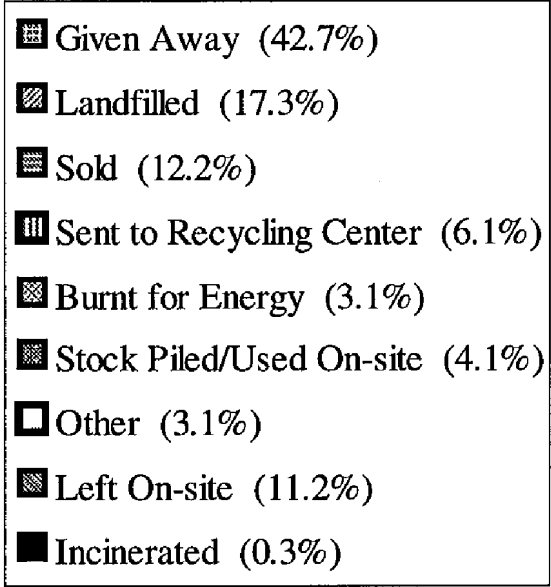

Figure V-1. Estimate of wood waste management methods in the United States Generated from Table V-1

\section{Markets for Urban Wood Waste Products}

Table V-1 shows that, of the 24 million cubic yards of urban wood waste sold each year, most is in the form of mulch (41\%) or firewood (25\%) (see Figure V-2). The remaining $36 \%$ is sold as boiler fuel, compost, wood products, or other products (NEOS Corporation, 1994). Urban wood waste is not used as a raw material to produce wood pellet fuels because its high potassium content can contribute to the formation of clinkers. 


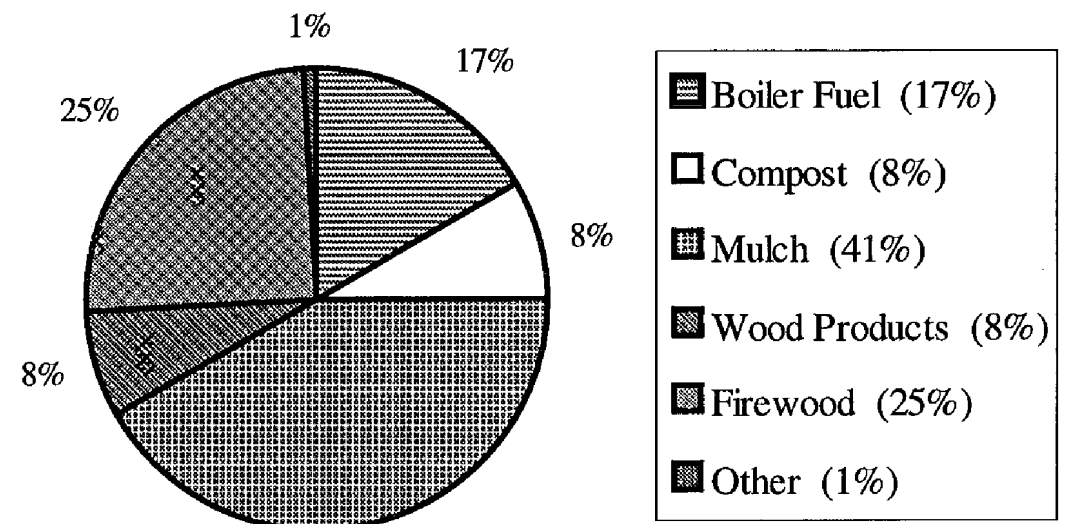

$41 \%$

Figure V-2. Distribution of urban wood waste product markets in the United States Generated from Table V-1

\section{Trends in Urban Wood Waste Management}

The ISA Research Trust Study indicates that $38 \%$ of the participants were not satisfied with their current urban wood waste management methods. Ninety-five percent of the $38 \%$ were interested in exploring new management options. Furthermore, $69 \%$ of all respondents stated they were interested in alternative methods for managing their urban wood wastes (NEOS Corporation, 1994).

\section{Case Study Overview}

Fourteen case studies of current urban wood waste management systems were conducted. The names and locations of the case studies are indicated in Figure V-3, a United States map of case studies. These facilities, while very different, share a number of commonalties that help make them successful and therefore useful to organizations facing urban wood waste challenges. These commonalities include:

- Tailoring the project within the context of the community in which it is implemented

- Forming cooperative efforts between the public and private sector

- Maintaining flexibility both in materials processing and products

- Conducting research into potential markets during the planning stages

- Undertaking ongoing research and experimentation, especially in markets and products

- Achieving and maintaining a good reputation with the public as a good neighbor

- Producing a high quality product

- Working closely with local and state regulatory and enforcement officials. 


\section{Case Study Selection}

The sites chosen for case studies were selected to reflect diversity in a number of ways: geography, range of management practices, technology, demographics, management practices to address episodic events, and management structure. The facilities described in this section utilize a variety of technologies, including composting, co-composting, mulching, land application, combustion, grinding, and vermiculture.

The case studies do not include applications such as use of landfills, biosolids composting, cocombustion, and bioconversion systems for a variety of reasons. Landfills were not included because, in states where landfilling of wood wastes is banned, an assessment of landfills would not be useful. Biosolids composting operations were not included largely because urban wood waste that is quite moist generally is not the waste wood of choice for this technology. While several of the facilities described in the case studies have sold their urban wood waste as a biomass fuel, cocombustion facilities were not included in this study because very few co-combustion facilities use urban wood waste as a fuel. Most biomass fuel used in co-combustion facilities comes from pallets, C\&D wood, industrial wood, and wood from silvaculture activities. Facilities using bioconversion were not included because of an inability to locate any facility using bioconversion as a management option for urban wood waste. Table V-2 gives a brief summary of management and demographic background of the case study participants.

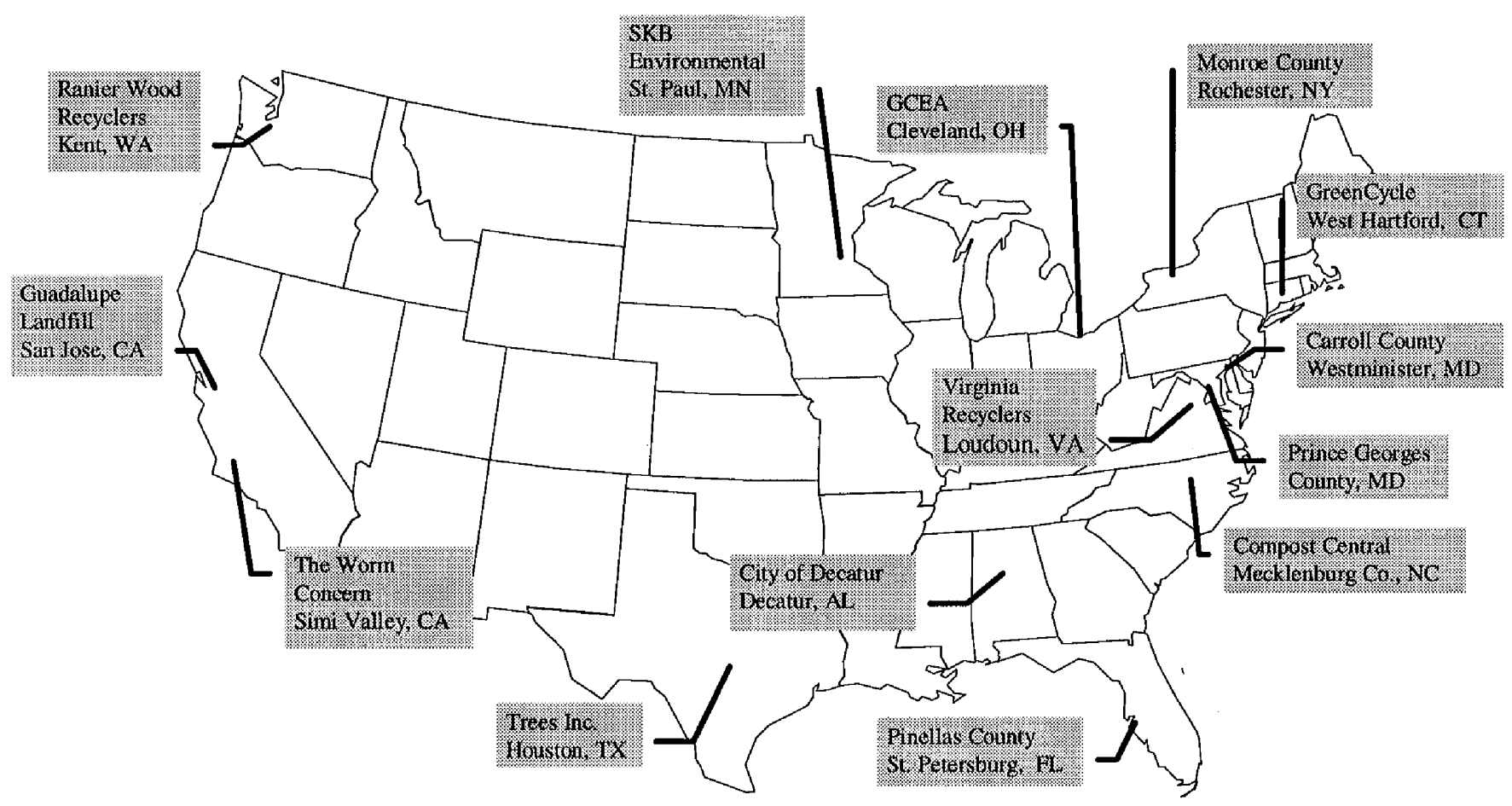

Figure V-3. United States map of case studies 


\section{Case Study Format}

A standard case study format and information base was established in consultation with the advisory group and was pilot tested in the field. The major elements of the case study format included the following.

- Background: Highlights of the particular case study, including a short description of quantities and types of urban wood waste being managed and the organizations involved.

- Regulatory and Policy Issues: A discussion of any regulatory and policy initiatives that have affected the organizations involved in the management.

- Management Practices: A description of management practices and technologies utilized.

- Environmental Compliance: A description of the environmental measures associated with the management system.

- Costs/Economics: A summary of costs associated with the wood waste management system.

- Lessons Learned: Key points about the system.

- Contacts: Key contacts for follow-up. 
Table V-2. Summary of Case Study Findings

\begin{tabular}{|c|c|c|c|c|c|c|c|c|c|c|c|c|}
\hline \multirow[t]{2}{*}{ Varne of Tacility } & \multicolumn{4}{|c|}{ Managenent Strictrare } & \multicolumn{3}{|c|}{ Beringrapling } & \multicolumn{5}{|c|}{ Marnagenenent Practies } \\
\hline & Private & Public & $\begin{array}{l}\text { Non } \\
\text {-Profit }\end{array}$ & $\begin{array}{l}\text { Public/ } \\
\text { Private }\end{array}$ & Urban & Suburban & Rural & Mulch & Compost & $\begin{array}{l}\text { Combus- } \\
\text { tion }\end{array}$ & $\begin{array}{l}\text { Land } \\
\text { Applied }\end{array}$ & Other \\
\hline Carroll County Landfill, MD & & $\mathrm{x}$ & & & & & $\mathrm{X}$ & $\mathrm{X}$ & $X$ & $x^{a}$ & & Give Away \\
\hline City of Decatur, AL & & $\mathrm{X}$ & & & & & $\mathrm{x}$ & $\mathrm{X}$ & $\mathrm{X}$ & & & Give Away \\
\hline Guadalupe Landfill, CA & $\mathrm{X}$ & & & & $X$ & $\mathrm{X}$ & & $X$ & & $x^{b}$ & $\mathrm{X}$ & Furniture \\
\hline Greater Cleveland Ecology, $\mathrm{OH}$ & & & $\mathrm{X}$ & & $\mathrm{X}$ & $\mathrm{X}$ & & & $\mathrm{x}$ & & & \\
\hline GreenCycle, CT & $\mathrm{x}$ & & & & & $\mathrm{X}$ & & $\mathrm{X}$ & $\mathrm{X}$ & & & \\
\hline Mecklenburg County, NC & & & & $\mathrm{X}$ & $\mathrm{x}$ & $\mathrm{x}$ & & & $\mathrm{X}$ & $x^{c}$ & & \\
\hline Monroe County, NY & & $\mathrm{X}$ & & & & $\mathrm{X}$ & & $\mathrm{x}$ & $\mathrm{x}$ & & $\mathrm{x}$ & $\begin{array}{l}\text { Diversion, Firewood, } \\
\text { Transfer Station }\end{array}$ \\
\hline Pinellas County, FL & & $\mathrm{X}$ & & & $\mathrm{X}$ & $\mathrm{X}$ & & & $\mathrm{X}$ & & & Give Away \\
\hline Prince George's County, MD & & & & $\mathrm{x}$ & & $\mathrm{x}$ & & & $\mathrm{x}$ & & & \\
\hline Rainier Wood Recyclers, WA & & $\mathrm{X}$ & & & $\mathrm{x}$ & $\mathrm{X}$ & & $\mathrm{X}$ & & & & Mobile Grinding \\
\hline SKB Environmental, MN & $\mathrm{X}$ & & & & $\mathrm{x}$ & $\mathrm{X}$ & & $\mathrm{X}$ & & $x^{d}$ & & \\
\hline Trees Incorporated, TX & $\mathbf{x}$ & & & & $\mathrm{X}$ & $\mathrm{X}$ & & $\mathrm{X}$ & & $\mathrm{x}$ & & \\
\hline VA Recyclers, VA & $\mathrm{X}$ & & & & & $\mathrm{X}$ & & $\mathrm{X}$ & $\mathrm{x}$ & & & \\
\hline The Worm Concern & $\mathrm{x}$ & & & & & $\mathrm{x}$ & & & $\mathrm{x}$ & & & \\
\hline
\end{tabular}

Notes:

a. They sold mulch as boiler fuel from 1979-1993.

b. Originally set up project to sell mulch as biomass fuel, but subsidy ended.

c. Sell mulch pallets as boiler fuel.

d. Currently nunning test burns on shredded pallets and wood waste for co-generation in conjunction with St. Paul District Energy. 


\section{Case Studies \\ Carroll County Landfill \\ Carroll County, Maryland}

\section{Background}

Carroll County (population 124,000 in 1990) is experiencing rapid transition as the Baltimore metropolitan area pushes residential development into formerly rural areas of the county. This factor has influenced the development of Carroll County's Solid Waste Management Plan which identified yard waste as a segment of the (MSW) stream that could be reduced to extend the life of the current landfill (capacity will be reached by the year 2007). Also, extending the life of the current landfill by reducing the amount of yard waste could reduce costs and public opposition to the planned construction of a new landfill facility. Carroll County's wood waste processing facility is located atop a closed portion of the county's 220-acre MSW landfill. Wood wastes are processed on a one-acre paved pad built on top of a closed landfill cell. The facility accepts all types of segregated clean wood waste including yard waste, brush, pallets, untreated wood used in building, and land-clearing debris. Logs are also accepted if they meet the proper specifications, but stumps are prohibited. These wastes compose $20 \%$ of the landfill's incoming materials.

\section{Regulatory/Policy Issues Affecting the Establishment and Management of Urban Wood Waste Systems}

Under Environment Article 9-1724, the State of Maryland bans source-separated yard waste from refuse disposal unless it is to be composted or mulched. Additionally, Carroll County's Solid Waste Management Plan bans the disposal of yard waste in the county's MSW landfill. If the material is segregated it can be taken to the county landfill and placed in a wood waste holding area at no charge to the hauler. Both regulations have facilitated the establishment of Carroll County's yard waste processing facility at its landfill to mulch incoming loads of wood waste that would otherwise have been disposed of in the landfill.

\section{Management Practices}

Wood wastes are delivered to the facility by municipal waste haulers, commercial landscape businesses, land-clearing operations, and county residents, who are the only ones not charged. All of the materials are separated into several piles depending on the processing needed and ultimate end product desired. Once enough material is collected for processing, it is reduced in size using a tub grinder. The ground wood waste is then placed in mulch piles or windrows for composting. While the facility accepts grass and leaves in plastic bags, the residents are encouraged to empty and remove their bags. The remaining bagged material is debagged by a prison labor force or by a Wildcat compost turner. County residents delivering materials usually leave with a load of mulch or compost often before the compost has cured completely. In addition to residential use, the mulch is used in the county park system on horse and hiking trails. Green wood chips are used within the pulp industry as feedstock for paper production. Other wood chips are used as fuel at facilities in both Pennsylvania and Virginia. The facility is currently researching the possibility of using an adjacent rail line for transporting fuel wood chips. This may help to lower the cost of shipping bulk material. 
NREL AAE-4-14077-01

\section{Economic Factors and Costs}

Although it is known that the facility received $\$ 120,000$ in state grants for equipment and paving expenses, no specific figures regarding the actual cost to establish, maintain, and operate the Carroll County facility could be found during this study. 


\section{Decatur-Morgan County Landfill Decatur, Alabama}

\section{Background}

The Decatur green waste recycling program began in October 1991 following more than a year of planning. The program was developed as part of the comprehensive recycling program for the Morgan County Solid Waste Management Plan that was required by Alabama legislation in 1989. The program includes curbside collection of recyclables from Decatur's 17,000 single and duplex households, the City of Hartselle's 4,000 households, and 14 drop-off recycling sites located throughout Morgan County. The Decatur-Morgan County Landfill yard waste management program began as part of the Morgan County Solid Waste Management Plan to recycle the yard waste component of the (MSW) stream. Only the City of Decatur (population 53,000) collects yard and wood waste for processing at the landfill and accounts for approximately $90 \%-95 \%$ of this waste stream of 15,600 tons. Other sources of wood waste are commercial landscapers and small businesses disposing of pallets. All yard trimmings and wood waste are accepted, except railroad ties, treated lumber, and building demolition waste. Three employees manage the operation (Morehead, 1994).

\section{Regulatory/Policy Issues Affecting the Establishment and Management of Urban Wood Waste Systems}

The City of Decatur began a green waste recycling program in October 1991 in compliance with 1989 Alabama legislation to curb the disposal of yard and wood wastes from the county MSW landfill. The Decatur-Morgan County Landfill was chosen as the site for green waste processing.

Plans for the chipping and composting sites were submitted to the Alabama Department of Environmental Management (DEM) for approval. Leachate and run-off controls were required by the Alabama DEM and submitted with the plans before approval.

\section{Management Practices}

Yard trimmings, brush, and tree trimmings are collected curbside by the city refuse department using loaders attached to the trucks or following behind the twelve vehicles used for collection. Great effort is exerted to achieve clean material. Residents are reminded in frequent media releases not to mix trash with yard and wood waste. All materials are collected, regardless of size, although residents are asked to trim to 5-foot lengths. Approximately 95\% of Decatur's green waste goes to the composting program. Any trimmings and wood waste, including pallets, land-clearing debris and clean, untreated wood scrap resulting from commercial operations, are hauled to the landfill by the commercial operation. Vehicles hauling trimmings and wood waste are weighed on scales and charged at the landfill. Prescreening is an important process; therefore, both laborers and metal detectors are used to keep the finished product clean. A rubber tire loader with a bucket is used on the chipping pad for sorting materials, moving materials, loading the wood hog, and loading outbound trucks (Morehead, 1994).

Mixed yard trimmings with wood 2 inches in diameter or less are chipped together to produce a mulch. Mixed yard trimmings and wood waste are chipped using a custom-designed and -built 600-horsepower horizontal feed wood hog. The hog is controlled by the operator who sits in the 
cab of a knuckleboom crane to monitor for contaminants and feed material onto the conveyor. A horizontal, variable speed, vibrating conveyor feeds wood and yard trimmings into the hog. The conveyor will stop if metals are detected by a metal detector as materials are fed into the hog and broken down by hammers, grates, and anvils. The mulch that is composted is monitored for temperature and turned when necessary. No screening equipment is used because this tends to lower the marketability of the end-products. Thus the material is given away as is, but due to controls on feedstock, the resulting material is uniformly fine in size.

Most of this material is sold "green", in bulk, without composting. Approximately 800 tons is windrowed, turned twice each year, and transported to a city park for distribution at a free public giveaway event. The green mulch is also sold to a soil producer who combines the mulch with bark, and then bags and sells the product to landscapers. Wood chips from the operation have been used as a road base during rain events and for daily cover at the landfill. The remaining material greater than 2 inches in diameter, pallets, construction debris, etc. is chipped and sold as boiler fuel to a local paper company. Approximately 5\%-10\% of the materials received at the chipping site are hauled by private contractors or haulers. The Decatur-Morgan Landfill is also working with Auburn University Extension Substation to test direct land application of green mulch to fruit trees and cotton crops. Research has been ongoing for three years and results so far have been positive and could yield an endorsement from Auburn stating that the product can benefit farmers by organically enriching their fields

\section{Economic Factors and Costs}

The composting program has been funded through the landfill which is an enterprise account managed by the Decatur City Council. In 1993 the facility received a grant for computer equipment from the Tennessee Valley Authority and the Alabama Department of Economic and Community Affairs. All materials are charged at the \$21 per ton tipping fee (Morehead, 1994). Tables V-4 and V-5 summarize operating costs for the program.

Table V-3. Capital Costs for Start-up in 1990-1991 Decatur-Morgan County Landfill, Decatur, Alabama

\begin{tabular}{||l|r||}
\hline Expenditure & \multicolumn{1}{c|}{ Cost } \\
\hline \hline Site design and preparation & $\$ 30,000$ \\
\hline Concrete pad (200X300X12) & $\$ 140,000$ \\
\hline Wildcat compost turner & $\$ 67,000$ \\
\hline Rubber tire loader (2 1/2 yd. bucket) & $\$ 120,000$ \\
\hline Wood hog & $\$ 394,000$ \\
\hline Electrical hookup & $\$ 17,000$ \\
\hline Leaf vacuums & $\$ 72,000$ \\
\hline Total & $\$ 840,000$ \\
\hline
\end{tabular}


NREL AAE-4-14077-01

Table V-4. Annual Costs for Last Budget Year Decatur-Morgan County Landfill, Decatur, Alabama

\begin{tabular}{|l|r|}
\hline Utilities & $\$ 25,000$ \\
\hline Labor (2 operators, 1 laborer) & $\$ 90,000$ \\
\hline Maintenance & $\$ 33,000$ \\
\hline Depreciation & $\$ 58,000$ \\
\hline Total & $\$ 206,000$ \\
\hline
\end{tabular}

Annual revenue was $\$ 30,000.00$ yielding a net expenditure (budget) of $\$ 176,000.00$. This calculates to a cost per ton of material of $\$ 11.28$. 


\section{Guadalupe Landfill San Jose, California}

\section{Background}

Guadalupe Landfill has a unique management structure. Guadalupe is one of two landfills (the other is Palo Alto) aligned in a private management structure to market products. Guadalupe also has a contractual relationship with the City of San Jose under which Guadalupe is responsible for picking up all of the city's urban wood waste. The arrangement includes contracts with several trucking companies to lower the cost of transporting the assortment of marketable end products.

Guadalupe Landfill's green and wood waste processing operations began following an awarded contract signed with the City of San Jose in 1991, when the city initiated a program to recover residential green and wood waste for recycling diversion goals. Guadalupe was prompted to enter the urban wood waste processing business primarily by two State policies: California's aggressive recycling goals, and the availability of subsidies for construction of co-generation facilities and biomass fuel generation. While California does not ban the disposal of urban wood waste at solid waste disposal facilities, it does have an aggressive recycling goal that has driven the establishment of urban wood waste processing facilities. The statewide subsidy was initiated in the early $1980 \mathrm{~s}$, but was cut in the early - mid- 1990's. When this subsidy ended, so did the primary market for urban wood waste managed at Guadalupe. However, Guadalupe successfully found new markets for its urban wood waste that include land application on area agricultural fields and reprocessing redwood into new furniture.

Approximately 1,000-plus tons of green and wood wastes are collected and processed daily by three landfills (including Guadalupe) from the surrounding communities including the City of San Jose's curbside recycling collection, and also are delivered from self-haul landscape and land clearing operations. An analysis of incoming material shows that $60 \%$ of the material is green waste and $40 \%$ is wood waste. In terms of sources of the materials, residential curbside collection accounts for $80 \%$, landscaping debris, $10 \%$, land-clearing debris, $5 \%$, and other various sources, 5\%. The Guadalupe Landfill occupies 411 acres, with 110 acres used for landfill. After processing, 24 trucks, each loaded with twenty-five tons of green waste, leave Guadalupe Landfill each day, delivering the material for direct land application in agricultural areas, or to composting and co-composting operations of local growers and dairies.

\section{Regulatory/Policy Issues Affecting the Establishment and Management of Urban Wood Waste Systems}

The California Integrated Waste Management Act (CIWMA) is one driving force behind yard waste recycling. No state law bans yard waste from solid waste disposal facilities, but CIWMA requires cities and counties to reduce their waste streams by $25 \%$ by 1995 and $50 \%$ by 2000 , providing an incentive to reduce the yard-waste component of the (MSW) stream. Because yard waste is the second largest component of the MSW waste stream, accounting for $16 \%$ of the total MSW by weight nationally (U.S. EPA, 1994), California cities and counties implemented plans and regulations to recover these materials to aid in compliance with the CIWMA. The City of San Jose implemented such a plan to satisfy the requirements of the CIWMA goals. This helped Guadalupe Landfill expedite the establishment of a large-scale yard and wood waste recovery facility. 
A statewide project was implemented in the early 1980 's to subsidize the construction and price of co-generation facilities that utilized hog fuel. Guadalupe Landfill established a market for its mulch product as biomass fuel for the co-generation facilities. However, due to statewide budget reductions, the subsidy for the hog fuel is no longer being supplied to the co-generation facilities. As a result, many co-generation facilities have closed, forcing Guadalupe to develop new products and markets.

Guadalupe Landfill also has benefited from requirements imposed upon the California Department of Transportation (Caltran) which is responsible for maintaining California's freeways. Caltran must use materials that contain at least $50 \%$ recycled organic content on all freeway landscaping projects. Guadalupe Landfill provides a 2-inch recycled wood product that satisfies Caltran's requirements.

\section{Management Practices}

One of the most interesting characteristics of Guadalupe Landfill is the development of unique market niches that provide a variety of end products to local consumers. Guadalupe Landfill has been able to develop these products as a result of incoming redwood materials, delivered largely from demolition projects. The redwood debris is brought in separately and transported to New World Lumber, that reprocesses this wood for lumber or mulch. The segregated waste wood is used to create new products from recycled redwood, including redwood planters, hutches, decorative wheelbarrows and other items used in the home and garden. The products are sold under the name New World Lumber Furniture, a division of Guadalupe Landfill. Unsuitable redwood material is ground with a Diamond $\mathrm{Z}$ tub grinder to a 2-inch size and marketed as redwood mulch for ornamental top dressing and sold through Valley's Pride Landscape Products Organics, also a division of Guadalupe Landfill. All other wood and green waste materials are ground with the Diamond $\mathrm{Z}$ or Morbark tub grinder and passed through a 3-inch trommel screen. The material is either marketed and sold as mulch or windrowed for compost and sold. Wood that passes through the 3-inch screen is classified as green mulch and is set aside to dry for a short time. The materials then run through a tub grinder a second time (Grobe, 1994). The green mulch is used in direct landspreading on agricultural fields in a unique arrangement with local farms and orchards that is described in detail in the following paragraph.

An abundance of agricultural land and orchards exist in the countryside surrounding San Jose. The proximity to so many markets for green waste for land application, composting and/or cocomposting has enabled Guadalupe Landfill to develop highly specialized market niches. Agricultural markets account for $75 \%$ of the outgoing materials from Guadalupe Landfill. Guadalupe was able to develop and initiate a beneficial program where composted material is used in direct land application to agricultural fields in the surrounding agricultural communities. Farmers were encouraged to apply the mulch 2 to 4 inches thick and then disk the material into the soil to improve tilth (overall texture) and increase organic matter content. To help find sites and develop markets, Guadalupe Landfill hired a sales and marketing consultant to meet with county farm bureau members, farmers, and landscape and agricultural professionals to let them know about the beneficial uses of the product. The major constraint was convincing local farmers that the land-applied mulch, when spread and disked into the soil, could conserve moisture and fertilize the soil at a satisfactory level and at a lower cost than conventional methods. Guadalupe generally subsidized the transportation, spreading and disking costs of the fresh mulch in the initial stages; however, as the word got out and demand for the mulch increased, spreading and disking subsidies were discontinued. Several large commercial lettuce growers in Salinas Valley use the green and 
wood waste to combine with agricultural debris for co-composting, which in turn is used by the growers on their fields thereby reducing landfill costs. Additionally, local dairy operations market manure to agricultural applications, but high sodium content limits the amount of manure farmers can apply to their fields. Guadalupe Landfill has been able to supply dairy farmers with nearly sodium-free green waste to combine with manure to extend the amount of manure that can be applied. The response from local farmers is encouraging as the benefits of land-applied mulch and other composting alternatives are tested and proven. At the same time, Guadalupe Landfill is able to smooth out the peaks and valleys in the supply and demand for compost products. In addition, the 2-inch mulch material is land applied between rows in orchards and vineyards to conserve moisture and improve fertility where alternatives to till farming are practiced in order to limit erosion. Another market for the mulch and compost is Caltran, which uses the materials as a topdressing to suppress weed growth, conserve water, and suppress erosion along freeways in California. Landscaping operations and residents account for the remaining $25 \%$ of end-product consumers.

\section{Economic Factors and Cost}

The wood waste sector of Guadalupe Landfill is a for-profit business that sells products from processed wood waste materials. Since Guadalupe Landfill is a private enterprise, with a right to maintain confidentiality of company information, no specific figures could be ascertained regarding the actual cost to establish and operate the facility or the revenue generated from the various products. But some general operational costs are known. For example, the average operating cost for the trommel screen equipment is between $\$ 6-\$ 8$ per ton of material processed. Although operation and maintenance costs could not be ascertained, tipping fees for municipalities with green waste collection systems which contract with Guadalupe Landfill pay \$22-\$27 per ton of green waste delivered to the facility. All others delivering green or wood waste to the facility pay $\$ 12-\$ 24$ per ton. Commercial operations that self-haul to the facility pay $\$ 6-\$ 16$ per ton of clean wood waste that is segregated, a savings compared to the $\$ 12-\$ 24$ tip fee charged for unseparated green and wood waste. 


\section{Greater Cleveland Ecology Association Cleveland, Ohio}

\section{Background}

Greater Cleveland Ecology Association (GCEA) started in 1981 as part of an educational and recycling effort by participating communities, local conservation leaders, and the Ohio State University Extension Service. The organization currently operates independently as a non-profit corporation under the laws of the State of Ohio. The Association is directed by a Board of Trustees, who are elected annually for a one-year term; a director; an assistant; and a site operator. Ten municipalities $(1990$ population, 811,949$)$ participate in the program, paying a one-time membership fee of $\$ 3,000$. Thereafter, a reduced membership tipping fee is charged at the gate. Two facilities are operating at this time, managing mixed yard waste, grass clippings, limbs, leaves and trees. Additionally, the facilities accept mixed waste from landscapers and other residents, but these generators are charged a higher fee than participating members.

\section{Regulatory and Policy Issues Affecting the Establishment and Management of Urban Wood Waste Systems}

A statewide ban (HB 592) on the disposal of yard waste in (MSW) disposal facilities and incinerators was enacted in 1994. However, yard waste is permitted to be disposed of in MSW disposal facilities if it is already mixed with (MSW). Many communities had implemented yard waste separation programs on a voluntary basis in anticipation of a complete yard waste ban. But the fact that mixed yard wastes are being allowed in sanitary landfills has many of these same communities considering discontinuing costly yard waste separation programs. Although the statewide ban has expanded the roles and opportunities for yard waste processing facilities by assuring a supply of materials to recycle, the City of Cleveland (population 573,822) is a member of GCEA, but does not participate because its yard waste is mixed with (MSW) and can be disposed of in a sanitary landfill.

GCEA's operation has benefited from its designation as a Class IV facility by the State of Ohio. The Class IV designation exempted GCEA from stricter permitting requirements imposed upon other solid waste systems. However, under this designation the facility still must implement odor and leachate controls.

\section{Management Practices}

GCEA operates from two sites. Of the participating communities, five bring in mixed yard waste, while the remainder bring in only leaves and wood wastes. GCEA stores material on-site until enough has accumulated to begin grinding operations. A Case $721 \mathrm{C}$ or a John Deere front-endloader with a 3- or a 5-cubic yard bucket, and a grapple attachment, are used to transport and turn materials. GCEA contracts out services for a Willibald grinder to process source-separated yard and wood waste, and mixed yard waste that consist of commingled small and larger material. The material is ground to a uniform particle size to accelerate composting. GCEA employs a trapezoidal or "spacious windrow" system that is a cross between the static pile and the turned windrow. This trapezoidal method places the ground material in a pile about $175^{\prime}$ wide $\mathrm{x} 375^{\prime}$ long $\mathrm{x} 8$ to 10 feet high, with a flat top. 
There are advantages and disadvantages to this system.

- For GCEA, valuable space is conserved for a given area because more compost can be spread in hexagonal windrows than in conventional windrows.

- With less surface area exposed, more of the compost remains active inside the pile, and less surface area means odor problems are suppressed.

- The flat top absorbs more precipitation than individual windrows which means less runoff and greater moisture retention during dry periods.

GCEA discovered that the appropriateness of the structure of the compost pile, whether it is trapezoidal or a conventional windrow, depends on the site. The trapezoidal formation worked well at one facility situated on Lake Erie because the direct wind-flow off the lake helped maintain an even moisture balance. However, the second facility has a long history of being very wet and without wind flow sufficient to balance the moisture of the trapezoidal formation. Therefore, the windrow formation works better at this facility.

As necessary, the pile is flipped using one of the front-end loaders, starting on one side and going back and forth with a mechanical turner. The turner uses a vertical drum to shred the compost from the side of the pile, and then it fluffs and transfers the compost by conveyor to a new pile on the other side of the machine. Turning is done about every three weeks, or as needed, dependent upon temperatures remaining under $120 \mathrm{~F}$. When the yard waste is fully composted (that takes from six to twelve months), it is processed through a Read 90A screener with half-inch openings.

GCEA operates as a state-designated Class IV composting facility and no permit is required because the operation handles yard waste only. However, the state does require odor and leachate control and monitoring. The trapezoidal design employed retains enough moisture to significantly decrease leachate generation. GCEA observes daily wind speed and direction to manage odor. Also, material is processed in winter to minimize odors.

The material is sold to homeowners, landscapers, and garden centers. GCEA promotes screened leaf humus as a soil conditioner. Leaf humus breaks down heavy, pan-clay soil, making it more manageable. Depending upon the needs of the customer, the leaf humus can be mixed with sand and topsoil to build beds for planting or is mixed with sand alone to create a peat soil. GCEA contracts for delivery services from two trucking outfits. They will deliver up to ten cubic yards of the products to homeowners; commercial operations can receive hundreds of yards.

\section{Economic Factors and Costs}

Presently, retail sales are $\$ 26$ per cubic yard. This price includes delivery and tax; however, if the customer picks up at the site the cost is $\$ 20$ per cubic yard. Commercial customers can pick up at the site for $\$ 12-\$ 14$ per cubic yard. This price is structured with the idea the more you purchase, the less you pay per unit.

In 1994, the cost to process 100,000 cubic yards of yard waste, including personnel, equipment, supplies, was $\$ 300,000$. Most of this expense was for leasing, contracting and rental of equipment. The cost to grind yard waste was $\$ 189$ per hour. Approximately 200 cubic yards per hour was ground, bringing the cost to about $\$ 1$ per cubic yard. The Read $90 \mathrm{~A}$ screener was unable to screen material at a rate sufficient to sell to the end product for a profit; therefore, an additional 
NREL AAE-4-14077-01

screener was rented for $\$ 5,000$ per week. A total of 12,000 cubic yards of finished product was sold.

Although GCEA does not pay any lease fees for the land where the facilities are located, their current lease on the facility itself expires October 31, 1995, at which time they must relocate. 


\section{GreenCycle of the Northeast West Hartford, Connecticut}

\section{Background}

GreenCycle Incorporated of Northfield, Illinois, organizes and provides financing for companies across the country that provide yard waste composting services to municipalities, waste haulers and landscape contractors. GreenCycle companies also develop the capability to market highquality end-products produced by individual sites. GreenCycle of the Northeast, a subsidiary of GreenCycle Inc., has entered into several public-private partnerships with municipalities by funding and executing the development and operational aspects of municipal wood waste management. GreenCycle of the Northeast consists of three composting facilities and two yard waste transfer stations serving the City of East Hartford, City of Wallingford, and other municipalities, private haulers and landscape contractors in central Connecticut. The facilities accept grass, leaves, brush, limbs, logs, stumps cleaned of dirt, and clean untreated wood. The material is accepted in bulk, in compostable paper bags, and in biodegradable plastic bags. The combined facilities' capacity is currently 100,000 tons per year.

The Town of West Hartford Transfer Station is just one example of a municipality employing the services of GreenCycle of the Northeast in a unique combination of yard waste transfer, composting, and wood waste processing facility. This facility began operation in October 1994, with the conversion and upgrade of a closed (MSW) combustion facility into a transfer station for the transport of leaves, grass clippings, and brush to a nearby GreenCycle composting facility. The West Hartford facility also composts leaves and grinds wood waste for mulch. The facility comprises seven acres, of which six acres are for leaf composting operations. The facility handles up to 10,000 tons of yard waste per year.

\section{Regulatory/Policy Issues Affecting the Establishment and Management of Urban Wood Waste Systems}

A General Grinding Permit allows the facility to process material on a small-scale basis while a Volume Reduction Permit allows processing of large-scale materials; however, a permit does not exist that will allow the facility to process mixed yard waste together. There is no statewide ban on the disposal of yard waste in (MSW) disposal facilities. However, the State of Connecticut encourages the recycling of yard waste. In addition, several towns have established yard waste collection and processing operations, including West Hartford. These facilities assist GreenCycle's operations by providing yard waste materials to the facilities.

\section{Management Practices}

The facility accepts material from the Town of West Hartford, which collects leaves and bundled wood waste ( $<4$ inches diameter, $<4$ feet length, and $<60$ pounds) from approximately 60,000 residents, and materials from 600 commercial accounts. The incoming vehicles are weighed on a 24 foot scale at the entrance to the transfer tipping floor, and assessed a per-ton fee that is lower than typical tip fees of other (MSW) disposal facilities. The incoming vehicles tip their loads and exit straight ahead. The material then is placed into two piles for deposit into the transfer trailers. A front-end-loader tips materials from the two piles into either a grass and leaf hopper (for compacting and trailer transport to GreenCycle's Ellington compost facility) or the brush hopper 
(for future grinding at the facility). GreenCycle believes in maintaining a highly mobile fleet of processing equipment, that can be broken down in a short time by one or two employees and transported among the various facilities. This maximizes operational efficiencies. An example of equipment mobility is the CBI "Grizzly" Roadmill 10-foot tub grinder that is transported among the GreenCycle Inc. facilities to grind wood waste when demand exists. In the future, the "Grizzly" will operate on the transfer trailer pad under the cover of the station for all-weather capability. Wood waste material receives a primary grind and screening, and then is put through a tub grinder a second time. The screener employed is a unique piece of equipment that was developed by the Scat windrow turner designer, using a screen shaped like a television satellite antenna that rotates to create a new screening technique. The cost is relatively low compared to larger trommels, and can be hauled by a small pickup truck of instead of the semi-tractor required by larger trommels. The large pieces are used for mulch and the unders (compost) are combined with leaf compost to help aerate the windrows.

The Frontier windrow turner is another example of mobility equipment. It can be towed down a highway as a legal load without the use of a trailer. The Frontier employs paddles, which are designed more like fan blades than the blades used in typical windrow turners. These paddles do the turning and mixing of windrows. The paddles allow for increased aeration of the windrows as the Frontier turns and mixes the material. The Frontier will be employed sometime in 1995 for composting operations in the Connecticut area. The composting process takes approximately 18 24 months. Longer composting enhances decomposition which improves marketability of the end product. Compost primarily is mixed for use as planting mixes for commercial operations. Mulch products can be dyed to satisfy customer demands for ornamental top dressings, or custom-mixed with leaf compost, sphagnum peat and sand in various quantities for growers. Mulch is also used as a bulking agent for biosludge composting.

\section{Economic Factors and Costs}

GreenCycle is a for-profit business that sells end-products from its processed wood waste materials. Since GreenCycle is a private enterprise, with a right to maintain confidentiality of company information, no specific figures could be ascertained regarding the actual cost to establish and operate the facility or the revenue generated from the various market products. 


\section{Mecklenburg County Compost Central Charlotte, North Carolina}

\section{Background}

Mecklenburg County's wood waste recycling program began in 1983, prompted by recycling mandates and a yard waste disposal ban imposed on (MSW) disposal facilities. Mecklenburg County conducted a solid waste audit that indicated that yard waste composed almost $20 \%$ of the residential solid waste stream. In response to the audit and the yard waste ban, Mecklenburg County established two yard waste collection sites. The first is an 8-acre facility and the second site is a 25 -acre site, both of which accept leaves, grass clippings, tree branches, and brush. They also accept clean pallets, spools, and crates, all of which are ground and sold as landscape mulch, pallet mulch, and boiler fuel. Stumps and land-clearing debris are not accepted. The management structure is public-private. New Solutions, Inc. has the exclusive rights to the compost and potting soil products and markets them under the line Eco Products, sold in stores such as Wal-Mart. The county charges New Solutions for each cubic yard of material the facilities receive, and the county receives a small commission at the end of each contract year. The County sells the mulch in bulk quantities. Of the 50,000 tons of material processed in 1993, residents accounted for $60 \%$ of endproduct users, while both municipalities and landscape operations accounted for $20 \%$ each.

\section{Regulatory/Policy Issues Affecting the Establishment and Management of Urban Wood Waste Systems}

A statewide law banning "yard trash" (brush, grass, tree limbs, and similar vegetative materials) from sanitary landfills went into effect January 1993 (North Carolina SWM Rules 15A NCAC 13B). This law, coupled by North Carolina's 25\% diversion rate goal for 1993, has aided in ensuring that an ample supply of wood waste is delivered to wood waste management facilities within the state.

\section{Management Practices}

Curbside collection is provided to 136,000 residents by the City of Charlotte and by contracted haulers, while landscapers drop off wood waste to one of the facilities. Eighty percent of the incoming material is from curbside collection. Of the remaining $20 \%$ of the total incoming materials, $65 \%$ is from landscape waste from unincorporated areas of the county, $30 \%$ is from residential yard waste, and the remaining $5 \%$ is from pallet debris. Wood waste is bagged in clear plastic, bundled, stacked or placed in open containers. Residents who don't receive curbside pickup may drop off wood waste at either facility for no charge.

The bagged wood waste is manually debagged either at the time of pick up or by the hauler at the facility. Wood waste at the curbside must be less than or equal to 6 inches in diameter and less than 5 feet in length. There is no size limit on material brought directly to the facility. The County also has three drop-off sites. Vehicles are weighed on a 50-ton scale at the entrance to the facility. Wood waste is tipped on one of three separate receiving pads. The material is processed within varying time frames, ranging from immediately to two weeks depending upon the season. Material larger than 6 inches in diameter is deposited next to a slow-speed shredder for initial size reduction prior to being ground in a tub grinder. The second tipping area is for brush, limbs, grass, leaves 
and any material less than 6 inches in diameter. This material is processed directly through a tub grinder. The third tipping area is exclusively for wood pallets. The pallets are processed separately through a tub grinder equipped with a magnet. The mulch produced from the pallets is sold directly to the public, with the excess material sold as boiler fuel. Wood waste destined for composting is ground in a tub grinder equipped with 2-1/2-inch screens for a balanced mix of fine material to bulky material, providing air space for windrow composting. After grinding, the material is placed in windrows 20 feet wide $\times 8$ feet high $\times 400$ to 1200 feet long.

After forming the windrows, a moisture content (MC) between $45 \%-55 \%$ is achieved within the first week with a water truck or natural processes, combined with the turning of the windrows to incorporate the moisture. No additional water is required to complete the process. Due to the large volume of water used to achieve the desired $45 \%-55 \% \mathrm{MC}$, surfactants, or wetting agents, are being tested in hopes of decreasing the volume of water required. A significant part of Mecklenburg's processing involves stabilization of the product for consistent quality material. The stabilization is achieved through testing for particle size, $\mathrm{pH}$, moisture content, soluble salts, temperature, carbon:nitrogen ratio and aeration. The carbon:nitrogen $(\mathrm{C}: \mathrm{N})$ ratio is evaluated regularly, and experience suggests that the incoming waste from spring until mid-fall generally can be expected to have an acceptable $\mathrm{C}: \mathrm{N}$ ratio. Leaves and winter waste that have a high $\mathrm{C}: \mathrm{N}$ ratio require the addition of ammonia-nitrate or urea to balance the ratio in order for complete composting to occur. Run-off and leachate are collected in a sediment pond that employs a rock filter before discharge. Samples are collected quarterly to monitor for pollutants exceeding state and federal standards. Run-off is diverted through the windrows to decrease the amount of water entering the sediment pond. The facility is located in an industrial complex, so odor complaints are not a problem.

Windrows are turned once weekly with a straddle-type turner, which can form either a flat-topped surface area for maximum water absorption or a peaked top to shed water. Temperatures are monitored weekly until $130 \mathrm{~F}$ is reached in two to three weeks; after six to eight weeks, temperatures reach and maintain $150 \mathrm{~F}$ for four months, and then decrease, indicating the composting process is coming to an end. When the compost temperature decreases to between 120 $-130 \mathrm{~F}$ the material is then fed into a 3/8-inch trommel screen by wheel loader where the fines (compost) pass a vacuum arrangement that removes any plastic or foreign material. The fines are then conveyed into a dump truck for curing and sold as compost. The over-sized pieces are conveyed into a 1-inch trommel screen where any remaining overs are destined for combustion. The ratio of fines to overs is $7: 1$. The screened compost will sit for another couple of weeks to cure. The material will compost for seven months with a volume reduction of approximately $65 \%$.

In addition to the processing of the incoming materials, the Mecklenburg County Solid Waste staff designed and installed an innovative method of educating local citizens about the benefits of composting at home. The staff, in conjunction with local landscape and agricultural professionals, created an educational center called the "Compost Garden" that features hands-on displays showing how composting can benefit the garden and how compost can be created and used. The "Compost Garden" sits on a 1/2-acre site that is open to visitors daily. Tours and information are presented by staff persons on certain days. This garden contains more than 50 types of plants, flowers, herbs, melons, and vines growing in compost-amended soil. 
This garden includes the following:

- A butterfly garden

- An herb garden featuring more than 25 herbs

- A xeriscape area for plants that need little water to survive

- A variety of melons and gourds growing up a circular stand of bamboo poles

- More than a dozen active composting bins, including a "worm bin" to demonstrate the use of red worms in composting.

\section{Economic Factors and Costs}

The source of funding is a residential user fee and sales revenue, which covers $75 \%$ of the operation's annual budget. The landfill tip fee is $\$ 29.50$ per ton compared to the $\$ 13$ per ton tip fee charged by the county yard waste processing center. The total expenses for the facilities' operation averages approximately $\$ 9$ per ton of processed materials. The site is leased for $\$ 1$ per year. The budget is as follows:

Table V-5. Compost Central, Yearly Budget Charlotte, North Carolina

\begin{tabular}{|l|r|}
\hline Annual Budget & $\$ 480,000$ \\
\hline Revenue & $\$ 300,000$ \\
\hline Equipment Cost & $\$ 1,450,000$ \\
\hline Maintenance Cost & $\$ 191,000$ \\
\hline Asphalt Pad Cost & $\$ 500,000$ \\
\hline
\end{tabular}




\section{Monroe County Rochester, New York}

\section{Background}

In Monroe County, approximately 120,000 tons of yard waste are generated each year. Yard waste is approximately $17 \%$ of the (MSW) (MSW) stream; this is second only to paper. Monroe County (population 714,000 in 1990) created the yard waste management program as a cooperative venture involving the public and private sector. The County works with the City of Rochester and its 29 surrounding towns and villages to help them set up their own leaf composting and brush chipping operations. A unique partnership exists between residents and the Monroe County government. The Monroe County Environmental Management Council formed a committee to seek public input into government policy issues related to yard waste management. The committee consists of individuals who represent various sectors of the community. The county is primarily responsible for the residential educational programs, technical assistance, planning and reporting activities, and serves as a liaison to the regulatory community. In addition, the county works with a yard waste focus group consisting of the local lawn care professionals, equipment dealers, and retailers to design and implement effective programs that will serve their needs. In 1992, approximately $30 \%$, or 35,000 tons, of yard waste was recycled countywide, not including land application of leaves. Table V-7 provides a breakdown of generator categories and amounts recycled.

\section{Regulatory and Policy Issues Affecting the Establishment and Management of Urban Wood Waste Systems}

Although yard and wood waste are not banned from MSW landfills in the State of New York, the state has implemented recycling goals to recover materials prior to disposal in MSW landfills. In response to New York State goals, the 1990 Monroe County Solid Waste Management Plan (MCSWMP) set a recycling rate goal of $40 \%$ of the waste stream by 1997. The MCSWMP has assisted the county landfills in implementing yard and wood waste recovery facilities, as well as establishing the groundwork for a public education program. However, the lack of a statewide ban and low landfill tipping fees have encouraged the commingling and out-of-county exporting of some wood waste.

In April 1993, the New York State Department of Environmental Conservation (NYSDEC) issued the operating permit to Monroe County for the Mill Seat Landfill in the Town of Riga. The permit imposed a ban on the disposal of grass, leaves and brush in the county's landfill by December 1, 1994. The county agreed to the disposal ban after the NYSDEC indicated that a statewide landfill disposal ban or similar landfill permit restrictions for yard waste would be in place at the time of opening of the landfill. However, ultimately the NYSDEC did not impose a statewide ban or similar restrictions. As a result, the Mill Seat Landfill operates at a competitive disadvantage relative to other privately owned landfills in the region that have not imposed a ban. Haulers often choose to use other disposal facilities to avoid the cost of additional source-separation programs. 
Table V-6. Comprehensive Recycling Analysis of Yard Waste Statistics and Projections

Monroe County, New York, 1995

\begin{tabular}{|l|r|r|r|r||}
\hline \multicolumn{1}{|c|}{ Material } & $\begin{array}{c}\text { \% of Total } \\
\text { Waste Stream }\end{array}$ & $\begin{array}{c}\text { Tons Per Year } \\
\text { Before } \\
\text { Recycling }\end{array}$ & $\begin{array}{c}\text { Tons } \\
\text { Recycled }\end{array}$ & $\begin{array}{c}\text { \% } \\
\text { Recycled }\end{array}$ \\
\hline Brush & 2.94 & 40,395 & 30,481 & 75 \\
\hline Wood & 2.64 & 36,240 & 13,977 & 38 \\
\hline $\begin{array}{l}\text { Land Clearing } \\
\text { Debris }\end{array}$ & 0.92 & 12,605 & 10,781 & 85 \\
\hline Grass* & 2.34 & 32,112 & 14,365 & 44 \\
\hline Leaves* & 2.68 & 36,714 & 30,799 & 83 \\
\hline Totals & 11.52 & 158,066 & $\mathbf{1 0 0 , 4 0 3}$ & $\mathbf{6 3}$ \\
\hline
\end{tabular}

* Monroe County runs waste reduction programs requesting residents to home compost leaves and "grasscycle" (grasscycle is a program encouraging residents to leave grass clippings on their lawns) as often as possible. Waste reduction quantities are not available.

Source: Lynn Schramel, Solid Waste Coordinator. Monroe County Division of Solid Waste Department of Environmental Services.

\section{Management Practices}

The county accepts leaves, tree trimmings, and brush for recycling at county facilities. The county-run facilities process source-separated residential materials from homes, nurseries, commercial lawn care operations and some businesses. Yard waste from residences are collected by private haulers at curbside. The county owns and operates a brush-chipping operation at its solid waste transfer station, and it operates two small demonstration leaf composting projects. The county currently uses the equipment in an unused resource recovery facility to process sourceseparated wood waste materials. The resource recovery facility was originally designed to manufacture refuse-derived-fuel (RDF) from mixed solid waste; now shredders designed to shred garbage are used to chip brush and larger materials such as stumps for chips for nature trails. Market development research services are also provided to stimulate the demand for and use of products developed from yard waste. Woodchips are given back to citizens at a number of designated sites, and some municipalities deliver truckload quantities to their residents. In addition, the mulch product is sold for fuel, sold to landscapers for use as base for composting sites, and used in nature trails.

The Materials Exchange Listing, published by Monroe, Ontario, Genesee, Livingston, Orleans and Wyoming Counties, provides 10,000 businesses with a network of opportunities to locate users for surplus materials including urban wood wastes, or find free or inexpensive materials including wood chips and compost to conserve landfill space. The county operates a telephone recycling information line to answer questions regarding the products and locations of the distribution sites, as well as other solid waste programs. A number of yard waste management messages are available through the recycling information line on a seasonal basis, including "How to Grasscycle," and "Recycling Christmas Trees." 
The county currently has implemented an effective grasscycling campaign titled "Just Mow It," that encourages residents to leave grass clippings on the lawn to break down naturally, to help divert materials from local solid waste management facilities. Local haulers and municipalities have distributed literature highlighting the program, coupled with successful radio spots featuring the County Executive. A partnership between the county and the Monroe County Cornell University Cooperative Extension researched and developed a process whereby leaves are directly applied to farm land as an alternative to nitrogen fertilizer consumption. The program received a statewide Beneficial Use Determination for this practice from NYSDEC. The service has contracted with the Cornell Cooperative Extension to match up Monroe County farmers willing to accept leaves with haulers and municipalities that collect them. A specially modified manure spreader is available to farmers from the county for direct land application of leaves. This practice has been very popular because it reduces the amount of capital investment and site management necessary compared to composting.

Monroe County and the City of Rochester have a give-back program to provide citizens with leaf compost, brush, and firewood, that has been very popular. The county is working cooperatively with the state to request that the size of yard waste composting facilities, which are exempt from regulation, be increased. The county encourages the state to initiate and enforce yard waste management permit conditions fairly and equitably across the state, so that municipal organizations are not at a competitive disadvantage. The Monroe County Environment Management Council seeks public input into governmental policy issues relating to yard waste management through its Yard Waste Committee. Monroe County also has a Recycling Advisory Committee, composed of individuals who represent various sectors of the community. Finally, the county works periodically with a yard waste focus group composed of the local lawn care professionals, equipment dealers, and retailers to design and implement effective programs that will serve their needs.

\section{Economic Factors and Costs}

No specific figures could be ascertained regarding the actual cost to establish and operate the Monroe County facility or the revenue generated from end-products. 


\section{Pinellas County St. Petersburg, Florida}

\section{Background}

Pinellas County is the smallest and most populous county in the state. Population is expected to continue to increase, putting pressure on sanitary landfill capacity unless a new facility is constructed or other alternatives are implemented. A study of Pinellas County concluded that yard debris constitutes $22 \%$ of the solid waste stream. This study indicated that a large portion of the state recycling goals ( $30 \%$ by weight of solid waste) could be achieved by recycling yard debris. Through a cooperative effort among St. Petersburg Sanitation Department, Pinellas City Department of Solid Waste Management, Pinellas County Cooperative Extension Services, University of Florida Institute of Food and Agricultural Sciences, and 11 municipalities, a yard waste recycling program was established to help extend the useful life of the landfill and to satisfy the state's recycling goals. Pinellas County conducted a two-year pilot study, before the involved parties embarked on a large-scale endeavor, to demonstrate how yard waste can be processed into mulch. The cost of labor and equipment for windrow processing, reject disposal, and mulch distribution was funded through Florida recycling grant money.

As part of the study, the facility processed 400 tons of yard waste per week for a $\$ 15$-per-ton tip fee, compared to the $\$ 37.50$ per ton sanitary landfill tip fee, a $\$ 22.50$ savings to customers. The study findings established the cost effectiveness and recycling potential of a yard waste recycling program. Pinellas County concurred and established a five-acre facility resting on top of a closed landfill cell. Pinellas County collects brush, leaves, grass, and tree trimmings (up to 10 inches in diameter and $<6$ feet in length) from a 280 -square-mile area; stumps and bags are excluded. The facility processes between $13,000-15,000$ tons annually. The source is primarily residential areas that includes 12 cities and 24 municipalities with a combined population of 864,731 (1992). The end-products derived from the facility include mulch, erosion control material, landscaping mulch and compost, wetland mitigation materials, and landfill cover. Municipalities account for $65 \%$ of end-product customers, while landscaping organizations account for the remaining $35 \%$.

\section{Regulatory/Policy Issues Affecting the Establishment and Management of Urban Wood Waste Systems}

Florida's Solid Waste Management Act of 1988 mandated that, by 1994, each county recycle 30\% by weight of the solid waste generated. Also, a statewide ban on the disposal of yard debris in sanitary landfills, effective January 1992, served as a primary impetus for the establishment of the Pinellas County yard waste recycling facility. Additionally, \$27 million in grant funds was allocated by the State for disbursement over a five-year period to establish countywide recycling programs.

\section{Management Practices}

Wood waste is collected both at curbside by municipal trucks and at drop-off centers. Wood waste is debagged at curbside. Incoming material is tipped into a pile that will sit for one to two weeks. A contractor comes in about once a week to grind the material with a Jones "Mighty Giant" tub grinder with 5-inch and 3-inch screens. The ground material is transported with a John Deere front-end loader equipped with a 3.75 cubic yard capacity and a clam shell bucket attachment (4.5 
cubic yard capacity) with an extended arm, that places the material in rows 24 feet wide $\mathrm{x} 10$ feet high $\times 100$ feet long in the summer time, and 13 feet high $\times 70-80$ feet long in the winter. Each windrow contains approximately 350 tons of material. The temperature is tested for the first three days after the piles are placed, and also after the piles are turned laterally with the front-end loader. Also at this time, water is applied at a rate of 20 gallons per cubic yard to obtain an average moisture content of $35 \%-40 \%$. The rows are not watered in the summer, but they must be watered in the winter to maintain the proper moisture content. Thereafter, the piles are tested for moisture and temperature once a week. Within the first three weeks the mulch volume is reduced $20 \%-30 \%$. The piles are turned about every 21 days depending on temperature.

To ensure the highest quality controls while maintaining a weed-free product, temperature, moisture, and turning dates are monitored with an on-site map of windrow locations as well as a windrow tracking chart. After composting for at least 45 days, the material is processed with a Re-Tech 723 trommel screen with a 3/4-inch openings. The material is distributed to homeowners, landscapers and municipalities from 21 different locations throughout the county at no charge; the county also will deliver upon request. A free countywide mulch hotline is provided to residents for sites and information. Additionally, the mulch is used as a landscape border along a 47-mile hike/bike trail and for beautification projects along interstate highway medians. The material that is rejected from the processing due to low composting temperatures or contamination is used on site for road cover, landfill cover, and erosion control.

In addition to processing yard waste material to extend the life of the landfill, the county cooperative extension service developed an educational program titled "Don't Bag It" as part of a source reduction strategy to promote on-site mulching and composting efforts (Ragsdale, et al., 1992). Residents were instructed in mowing, watering, and fertilizing techniques to assist them with home composting and leaving grass clipping on the lawn to naturally break down.

\section{Economic Factors and Costs}

No specific figures could be found about the actual cost to establish operate and maintain the Pinellas County facility. 


\section{Prince George's County Landfill Prince George's County, Maryland}

\section{Background}

Prince George's County developed its yard waste recycling program in 1989 in response to the Prince George's County "Right to Recycle" legislation that established incremental recycling goals beginning with $10 \%$ in 1991 and reaching $35 \%$ by 1999 . To reach the goals it would be necessary to recover the yard waste component that is $15 \%$ of the (MSW) stream. The county selected two sites to process yard and wood waste from 75,000 county-contracted households, 18 municipalities, and landscapers. The Prince George's County and Maryland Environmental Service (MES), a quasi-private state agency, signed an Inter-Governmental Agreement (IGA) to manage and operate the two facilities and market the end-products for profit. The Western Branch (WB) compost site is a 47-acre paved site originally used as a waste water treatment plant. The facility accepts brush ( $<3$ inches in diameter and $<4$ feet in length), leaves and grass clippings. Vines, stumps, bamboo, and inorganic materials are not accepted. The Brown Station Road (BSR) Processing Area is located at the Brown Station Road Landfill. The BSR Processing Area accepts larger brush (3-9 inches diameter), Christmas trees, and pallets; however, stumps, leaves, and grass clippings are rejected. Once this larger material has been ground at the BSR, it is hauled to the WB facility to be composted. In 1993, the WB processed 10,000 tons of grass clippings and 20,000 tons of leaves and brush while the BSR processed 7,000 tons of brush and 3,000 tons of pallets. Each facility operates with a total of seven employees (Helmecki, 1994).

\section{Regulatory/Policy Issues Affecting the Establishment and Management of Urban Wood Waste Systems}

Prince George's County's "Right to Recycle" legislation sets incremental recycling goals of $10 \%$ for 1991 , and reaching $35 \%$ by 1999 . Because yard waste, including wood waste, represents $15 \%$ of the total waste stream, the county decided that yard waste would need to be recovered to achieve the $35 \%$ goal.

\section{Management Practices}

Beginning in November each year, bags of leaves and bundles of small brush are collected from residents on a designated collection day and are tipped at one of the facilities. The materials enter a Malin 500 slow-speed, high-torque, three-screw auger that bursts the bags, leaving them approximately $90 \%$ intact while separating the leaves. Brush is ground into small pieces and commingled with the leaf material, where any ferrous metal is separated from the yard waste by a magnetic head at the top of the assembly. Next, the commingled material travels along a conveyor where it enters a Amadus Industries 30-foot pre-screener. The pre-screener is equipped with 3.5inch openings throughout. However, a modification has enlarged some of the holes to 7 inches to increase production of the larger leaf material. The smaller yard material falls through to a lower conveyor where it is loaded into one of two live-floor, open-top, 45-foot trailers. The remaining plastic bags and larger material travel to another open-top trailer where the materials are transported to the county landfill.

The yard and wood wastes are off-loaded and placed in windrows on the pad until mid-January where they are turned approximately once a month through April when grass clipping are collected. 
As grass clippings are incorporated into the windrows, and nitrogen increases, the turning frequency increases to 1 to 2 times weekly. This is done, not only to facilitate the composting process, but also to alleviate any odor problems. Because the facilities incorporate an impervious pad, run-off and leachate from the windrows drain to a run-off collection pond that discharges to a local stream when the level reaches the elevation control risers. Samples have been collected from the windrows to test leachate characteristics. A four-foot square by four-inch high drip pan was placed on the bottom of the windrow. Data collected from the samples indicated a relatively lowstrength leachate. Because composting takes place on an impervious bituminous pad, significant quantities of stormwater dilute the relatively small quantities of leachate. The relatively low strength and diluted leachate contained no significant concentrations of any parameter analyzed, enabling the discharge of stormwater from the site without restrictions. However, $\mathrm{pH}, \mathrm{BOD}$, and suspended solids are monitored monthly. By September, the material reduces in volume by $50 \%$, and the resulting compost is screened using a 0.5 -inch final screener before distribution under the trade name Leafgro. MES markets and sells Leafgro on a minimum order quantity of five cubic yards at $\$ 9.50$ per cubic yard. The product is used by commercial landscaping operations, and it is sold in retail outlets to homeowners. Any remaining wood chips are sold to mulch producers, donated to civic groups for various applications (playgrounds, trails, etc.) or used on site to absorb excessive amounts of grass.

\section{Economic Factors and Costs}

In 1990, the Office of Recycling signed a long-term lease with the Washington Suburban Sanitary Commission for $\$ 1$ per year to use a vacant 44 -acre waste water treatment plant for a composting facility. The BSR Processing Area was sited at the county MSW landfill. The annual budget for both sites is approximately $\$ 1.2$ million. The facilities have a five-year lease for the purchase of initial equipment. The (MSW) landfill tip fee is $\$ 72$ per ton compared to the $\$ 10$ per ton fee charged for yard waste. The $\$ 10$ tip fee is subsidized by a portion of the landfill tip fee because the actual processing costs are $\$ 30$ per ton, of that the operation and maintenance costs to the facility are $\$ 23$ per ton. Without the landfill tip fee subsidy and decreased tip fee for yard waste, the facility would not be able to provide consumers with an end-product costing between $\$ 8-\$ 9$ per cubic yard, depending upon the size of the order. This subsidy and portion of the landfill tip fee revenue decreased the overall costs of the operation so that the county generated a profit: $\$ 40,000$ in revenue from product sales in 1993. 


\section{Rainier Wood Recyclers Kent, Washington}

\section{Background}

Rainier developed out of a community need for a lower cost waste management alternative to escalating landfill tip fees, coupled with outdoor burning restrictions. Rainier is a family-owned business that broadened its activities to process wood waste in 1986. Rainier has two facilities, averaging 10 acres per site where wood waste is processed into mulch. It also provides mobile onsite contracting services. The facilities receive waste wood of all types and sizes including brush, land-clearing debris, logs, and stumps of any size. In addition, they also process "white wood" from industrial, manufacturing, and construction operations. The sites do not accept leaves, grass, and soil from stumps, which are sent to a neighboring composting facility. Rainier has a contract with the City of Seattle to process its wood waste and also receive waste from other municipalities, contractors, refuse companies and self-haulers. Rainier chips brush and stumps removed from golf course expansion projects at a cost that represents a $2 / 3$ savings relative to the cost to landfill. Rainier processes between 600,000 and 750,000 cubic yards of wood waste and "white wood" from industry, manufacturing and construction per year. It produces 240,000 cubic yards of materials from waste wood a year. Approximately $60 \%$ comes from land clearing and self-haul operators with the additional $40 \%$ from contractors and contracts with cities.

\section{Regulatory and Policy Issues Affecting the Establishment and Management of Urban Wood Waste Systems}

Although a statewide ban on the disposal of yard or wood waste in (MSW) disposal facilities does not currently exist, the amount of wood waste generated in this Northwestern portion of the United States provides enough material for processing facilities and markets to successfully manage it. Further opportunities for Rainier have resulted due to a ban on open burning of wood waste. These factors have contributed to escalating landfill tipping fees higher than those charged by Rainier.

\section{Management Practices}

Incoming wood waste material is first inspected for contaminants. Next, trucks are weighed on an electronic scale with a computer tracking system. Tipped materials are segregated into piles based on size, with the brush and small logs going to one pile, larger brush and logs going to second pile, and stumps going to a third pile. The piles sit to dry out from anywhere between a week to six months depending upon the time of the year and volume of material. The wood waste is processed with a "Contender" grinder from the Universal Refiner Corporation (URC) that utilizes a unique grinding concept that is based on a pan and disc refiner. Twelve screens, ranging in size from 2-7 inches located along the bottom and outside of the turning pan, allow rock and metal to fall through without all the contaminants coming into contact with the cutting disc. This system extends the life and maintenance of the hammers when compared to traditional hammermills. An example of the lower maintenance requirements of the Contender is the time required for resurfacing the hammers. It is limited to just several hours per week instead of the required one to two hours per day for some hammermills. The screens are designed to last the life of the machine because they are not part of the grinding process. The cutting disc turns counter-clockwise and takes an 8-inch slice with each rotation producing 45-65 tons per hour output. Other operating equipment includes 
rubber tired loaders (CAT 966), four thumb-excavators (Komatsu 220s), and a fleet of trucks for deliveries.

Various mulch products are made depending upon material and screen size. Stumps are ground separately with a 2-inch minus screen to produce a mulch that is used with hydroseed on construction sites, corrugated medium, and as pulp chips. Brush and logs are ground with a 12inch minus screen to produce a mulch that is primarily used as animal bedding. This material can be ground a second time with a 4-5-inch minus screen to produce mulch that is used by construction and landscapers for road base, erosion control, landfill cover, and co-generation fuel; or as homeowner mulch. In addition, the mulch produced from the grinding of stumps is screened with a 3/4-inch minus screen to remove soil that is sold as soil amendment to a separate composting company that adjoins the property.

\section{Economic Factors and Costs}

Rainier is a private organization with a right to maintain confidentiality of company information; thus the amount of information ascertained regarding cost to establish and operate the facilities and the level of profit received from end-products is limited.

One-third of the company's revenues are derived from product sales, and $2 / 3$ of the revenues come from tipping fees. Their annual budget is two million dollars. Processing costs are approximately $\$ 38$ a ton. Maintenance is approximately $45 \%$ of processing costs. Rainier is working on decreasing and eventually eliminating tip fees due to the increasing market expansion of products. 


\section{SKB Environmental St. Paul, Minnesota}

\section{Background}

SKB Environmental was formed in 1983 as a wholly owned subsidiary of Carl Bolander and Sons Company. The subsidiary functioned as a complement to Bolander's demolition activities, providing cost-effective disposal services for construction and demolition (C\&D) debris. More recently, SKB has expanded its services to become the largest yard waste processing operation in the State of Minnesota for composting of leaves, grass clippings, and brush, as well as grinding of brush and other wood wastes into landscaping mulch. These services are provided by facilities throughout the St. Paul region, which includes the seven-county metropolitan area of Minneapolis. SKB also provides services under a contract with the City of Minneapolis (1990 population, $368,363)$. The facilities, which are open to receive materials from April 1-November 30, are described below:

- All yard waste for the City of Minneapolis is processed at the Bolander facility on approximately eight acres of a 17 -acre site.

- SKB Environmental owns and operates the Minnesota Valley Tree \& Yard Waste Recycling Facility, a 40-acre site that serves the public and waste haulers in the southern and southwestern portion of the Twin Cities Area. The facility accepts bagged and debagged leaves and grass, brush and wood waste.

- SKB is the contractor operating the Lakeville Yard Waste Compost Facility, on a 10-acre site within a 21-acre area. The facility was cooperatively funded by a consortium of four Minnesota cities: Lakeville, Apple Valley, Farmington, and Rosemont. The facility accepts debagged leaves and grass, and brush.

- SKB also operates the Owatonna Yard Waste Facility on approximately two acres of the City of Owatonna's site. The facility accepts debagged leaves and grass, and brush.

- The City of Cottage Grove's 20-acre compost facility, of which approximately two acres are used, is operated on a contractual basis with SKB. The facility accepts debagged leaves and grass, and brush.

- In 1993, SKB converted approximately 40,000 tons of leaves, grass clippings, and brush into compost; and 10,000 tons of wood waste and brush (no size limit) were processed into landscaping mulch at the five facilities.

\section{Regulatory and Policy Issues Affecting the Establishment and Management of Urban Wood Waste Systems}

Yard waste may not be disposed of or mixed with (MSW), in a (MSW) facility, or in a resource recovery facility except for the purpose of composting or co-composting under the 1988 Waste Management Act Amendments that went into effect in 1989. However, the state still grants permits for open burning and C\&D landfill disposal of tree and shrub waste generated by right-ofway clearing and grubbing, and by construction projects in sites without existing residential or commercial structure. 


\section{Management Practices}

Material is dropped off and screened for contaminants at one of four sites. The bagged leaves, which largely come in the fall, are stockpiled until early spring. The mixed brush arrives throughout the year and is stockpiled separately, with the larger logs and stumps separated into another pile. Brush and stumps are ground separately with a tub grinder and are either sold as mulch or mixed with leaves for compost. Leaves are debagged with a mechanized debagger. SKB has developed an engineered aerated static pile composting process. This process uses conveyer systems in conjunction with the tub grinders to achieve aeration of the material in addition to mixing the right amount of leaves and brush. This process is conducive to maintaining moisture and minimizing odors, to the point that no odor complaints have ever been registered. Each load of incoming material is visually inspected for contaminants when entering the facility and throughout processing. After mixing, the compost piles sit for a period ranging from 16 weeks to one year, and are turned an average of three times during this period. The compost material is screened before it is sold to homeowners, landscapers and nurseries. Mulch is used by contractors for highway landscaping, nurseries and landscapers. Additionally, pallets are ground to create animal bedding. SKB distributes a brochure highlighting facility locations, services and cost. SKB is currently running test burns on shredded pallets and wood waste for co-generation in conjunction with St. Paul District Energy.

\section{Economic Factors and Costs}

SKB Environmental is a for-profit business that sells products from the processed wood waste materials. Since SKB is a private enterprise, with a right to maintain confidentiality of company information, no specific figures could be ascertained regarding the actual cost to establish and operate the facilities or the revenue generated from the various end-products. 


\section{Trees, Incorporated Houston, Texas}

\section{Background}

Trees, Inc. contracted with Houston Power and Light in 1979 to process its utility right-of-way land clearing wood waste. From 1979 to 1993 , the company sold the processed wood waste as boiler fuel to a paper manufacturer 80 miles away. Trees, Inc. contracted with a hauling company to deliver the processed wood waste to the paper manufacturer. When the paper mill became selfsufficient in 1993 and no longer needed to import fuel, Trees Inc. contracted with a company that makes soil amendments. This company picks up the processed wood waste directly from Trees Inc.'s facility.

When this wood waste processing operation began, Trees, Inc. first used a disk chipper. Company officials were dissatisfied with the disk chipper's through-put and its high maintenance costs, so they investigated other processing equipment. They contacted manufacturers and conducted site visits in order to assess the operation of other grinding equipment and eventually purchased a horizontal hog chipper. Although the capital investment was high for this machine, Trees, Inc. officials feel that the investment will pay off because of the easy maintenance requirements, consistent product, increased production time, and decreased operating time. The horizontal wood chipper is much more efficient than Trees' previously grinder, producing the same amount of processed material using a five-person crew operating 10 hours a day, 5 days a week, that previously required 7-day operation with a five-person crew. This results in a weekly savings of 20 man hours. In addition, the new machine is electrically powered, so it is very quiet, and its hammers can last from six months to a year.

\section{Regulatory and Policy Issues Affecting the Establishment and Management of Urban Wood Waste Systems}

Trees, Inc. was awarded the contract from Houston Power and Light to process its wood waste in 1979. Prior to 1979 this wood waste was landfilled. Even though the landfilling of wood waste is still permitted in the State of Texas, Houston Power and Light decided to have the wood waste produced by right-of-way clearing processed because of economics. It was simply cheaper to contract out the management of this wood waste than to have it landfilled. Trees, Incorporated estimates that it saves Houston Power and Light up to $\$ 500,000$ dollars annually.

\section{Management Practices}

Wood waste is picked up from Houston Power and Light's five satellite drop off facilities that are located throughout the Houston Metropolitan Area. Trees, Inc. contracts with a hauler to pick up the wood waste from the satellite facilities and deliver it to the processing site. This two-acre site is located directly off a service road that feeds into a major highway. The waste consists of previously chipped material (wood waste that was chipped on site), tree branches, logs and brush material. Some of the wood waste material that is less than 4 inches in diameter is pre-processed by the right-of-way land clearing crews with mobile chippers. Larger wood pieces are cut into smaller pieces with a power saw. Once at Trees, Inc.'s facility, the wood waste is loaded onto the horizontal conveyer with a front-end loader. An operator monitors the operation from a control booth located next to the waste wood pile and above the horizontal feed conveyer. The operator 
controls the amount and rate of the material processed by controlling the speed of the chain that moves the horizontal conveyer. The hammers operate at a constant speed. An automatic dust control system is integrated within the hammer mechanism that virtually eliminates dust. After the wood waste is ground by the hammers, it passes over a 2 inch screen and the passing fraction is dropped onto a conveyer that has a magnet mounted at the top. After the material passes through the magnet, it is dropped onto a second conveyer. The second conveyer moves the material to a third conveyer that deposits the material into a storage pile. The first conveyer is at a 90-degree angle to the second and third conveyers, one of which is positioned above the other. This configuration minimizes the amount of space needed for processing.

Even though the facility is bordered on two sides by single family homes, noise and odor are not a problem at this site. Noise is minimized by using an electric motor to power the horizontal hog chipper. Odor is minimized by keeping the processed material in large piles ( $>50 \mathrm{feet}$ ), that discourages the decomposition, and by having the material picked up frequently.

The processed wood waste is very consistent and of high quality, with little contamination. The product consistency is attributable to the horizontal wood chipper, while the lack of contamination is due to two factors. The first is the magnet mounted onto the conveyer, that separates out ferrous materials. The second is the presence of an on-site guard stationed at the facility during nonoperating hours. This guard prevents midnight dumping, that previously had occurred at the site and contaminates the waste materials.

\section{Economic Factors and Costs}

Trees, Inc. is a for-profit business that sells products from the processed wood waste materials. Since Trees, Inc. is a private enterprise, with a right to maintain confidentiality of company information, no specific figures could be ascertained regarding the actual cost to establish and operate the facility or the revenue generated from the sale of their end-products. Trees, Inc. did state, however, that they believe they save Houston Power and Light $\$ 500,000$ dollars a year in landfill disposal costs. 


\section{Virginia Recyclers Chantilly, Virginia}

\section{Background}

Loudoun County (estimated 1995 population, 109,410) is a 512-square-mile area characterized by a rapidly expanding population and increasing construction activity as the Washington, DC, metropolitan area expands westward into vast areas of the previously rural county. As Loudoun County's population and development increases, county MSW disposal capacity will continue to shrink unless other management options are found, including truck transfer of trash to other counties or states. In April 1993, Loudoun County took steps to reduce the amount of material disposed of in the county MSW landfill by adopting landfill operational policies requiring that yard waste, brush, wood waste and concrete demolition debris be separated from municipal refuse. Virginia Recyclers, a facility privately owned and operated in conjunction with S.W. Rodgers Construction Company, was established in 1992 to provide wood waste mulching services to Loudoun County and various landscape and land-clearing operations from areas outside Loudoun County.

The Virginia Recyclers facility encompasses a 10-acre bermed site, of which eight acres are used for wood waste processing. One unique adaptation is a sprinkler system equipped with hydrants that runs the length of the facility road for fire suppression and watering of the mulch piles. The materials processed are essentially any arboreal wastes, including stumps, limbs, and brush from residential, commercial, and land-clearing activities. Any materials other than wood wastes are excluded from the facility. Land-clearing debris accounts for approximately $60 \%$ of the incoming wood waste materials, while landscape operations account for the remaining $40 \%$.

\section{Regulatory and Policy Issues Affecting the Establishment and Management of Urban Wood Waste Systems}

On April 1, 1993, the Loudoun County Board of Supervisors adopted operational policies requiring that yard waste, brush, wood waste, and concrete demolition debris be separated from municipal refuse. Loudoun County discourages the practice of mixing solid waste by charging more for mixed waste. If yard waste, brush, wood waste, or concrete demolition debris is mixed when delivered to the county-owned MSW landfill, an $\$ 80$ per ton fee is charged, versus the regular $\$ 55$ per ton. This policy has benefited Virginia Recyclers by providing wood waste material that would have otherwise ended up in the county MSW landfill.

\section{Management Practices}

Virginia Recyclers accepts all forms of arboreal waste from commercial landscaping operations, construction excavation and land-clearing operations. There is no size limitation on material. Material is delivered to the facility by commercial haulers that stop at an office trailer situated at cab-level so that receipts recording cubic yards delivered can be handed to haulers, and incoming loads can be visually inspected. The material receives a primary grind with a 14 -foot Diamond $Z$ tub grinder that processes 150 cubic yards per hour, or a Mobark 1400 tub grinder, provided as needed by S.W. Rodgers. The resulting 4-6 inch material is then passed through a Re-Tec trommel screen with a 3/8-inch opening to sort into three classifications. The initial grinding and screening of the material results in a 4-6 inch material and a 2-4 inch material. These materials are placed 
into separate piles for curing, or put through the tub grinder for a secondary grinding with a 2.5inch screen that separates the $3 / 8$-inch material. The $3 / 8$-inch material is placed into curing piles for three months, resulting in a dark and organically rich material that can be mixed with fines (e.g., sand) for use as a soil amendment. The larger material remaining from the secondary grind are chipped as "Tot lots" for use as a cushioned surface on children's play grounds. All of the mulch materials are stored in piles less than 20 feet in height and approximately 800 feet in circumference. Height is limited due to the maximum extension of the back-hoe used to turn the piles every two to three months. A storm-water collection pond collects run-off and any subsequent leachate. Samples are collected monthly for monitoring. A berm surrounds the facility to reduce noise, but the facility is located in an industrial area where noise is not a common complaint.

Approximately $75,000-80,000$ cubic yards of materials are sold yearly to large-scale commercial landscape and nursery operations from neighboring states, such as West Virginia and Pennsylvania. Materials from this facility provide landscaping material for several federal buildings in the Washington, D.C., metropolitan area including the Smithsonian Institute and the Pentagon.

\section{Economic Factors and Costs}

Virginia Recyclers is a for-profit business, that sells all of its products from the processed wood waste materials for $\$ 15$ per cubic yard. Since Virginia Recyclers is a private enterprise, with the right to maintain confidentiality of company information, no specific figures could be ascertained regarding the actual cost to establish and operate the facility or the revenue generated from the sale of their end-products. 


\section{The Worm Concern Simi Valley, California}

\section{Background}

The Worm Concern, located in Simi Valley, California, is a vermiculture (worm farming) operation established in 1991. Vermiculture is the practice of composting to achieve controlled degradation, or composting of organic wastes, primarily by earthworm consumption and subsequent castings (compost). The surrounding communities are a mix of semi-rural and suburban areas in Ventura County, northwest of Los Angeles. The Worm Concern has contracts with Eastend Ventura, Santa Rosa, and Simi Valley and serves at least six cities and the surrounding unincorporated East Ventura County. The firm operates on a 16-acre site located in the triangle of three cities. This includes 30,000 households in Simi Valley, Thousand Oaks, and Moorepark. Material is collected curbside in addition to material coming in from landscapers, tree trimmers, and other commercial accounts. Material 6 inches or less is accepted. The Worm Concern excludes stumps, construction and demolition (C\&D) wastes, and plastic bags. Other materials accepted are green waste clippings, tree trimmings, and some wood, in addition to horse manure from local farms. The facility is permitted to process 100 tons per day and receives approximately 50 to 100 tons daily.

\section{Regulatory and Policy Issues Affecting the Establishment and Management of Urban Wood Waste Systems}

As in the Guadalupe Landfill case study example, the California Integrated Waste Management Act (CIWMA) directly affects the operations of The Worm Concern. The Act has enabled The Worm Concern to win contract services from municipalities for the processing of yard waste to meet recycling goals.

However, The Worm Concern has encountered difficult permitting conditions. Permitting has been problematic due to the nature of the facility. It cannot be neatly categorized, and falls somewhere in-between a solid waste management facility and an agricultural facility. Vermiculture generally is recognized as an agricultural activity. However, California law requires composting facilities to be permitted through the same process applied to other solid waste facilities. The Worm Concern is working with state agencies to resolve this issue.

\section{Management Practices}

Wood and yard debris is delivered in a variety of vehicles that are weighed on motor truck scales. The recorded weight of the material is then used to charge haulers a tipping fee (disposal fee) for the use of the facility. The incoming material is placed into piles by a front-end loader. The accumulated material is then transported by the front-end loader to a tub grinder, that reduces the material to nearly consistent size. The resulting material is then conveyored to a trommel screen with 2-inch openings for sorting by size. The material 2 inches or less is then moved with the front-end loader to an area where it is layered thinly (maximum 12 inches deep) on top of the static windrows that begin as 1-3 feet deep by $8-10^{\prime}$ wide "mother beds" loaded with red worms. Because worms tend to live naturally in the top layers of soil, the fresh debris and thin layers help maintain aerobic conditions for the worms and accelerates the breakdown of the material. Also, the thin layers reduce the chance of causing temperatures fatally high for the worms. Fresh material is 
added weekly, and after approximately eight layers (60-90 days), the windrow's bottom, containing the worm castings, is ready for harvest. The compost has a $3: 1$ compost:worm castings ratio. One cubic yard will cover 100 square feet. The worms are harvested with a pitch fork, loaded in a front-end-loader, and put through a trommel screen where the worms are separated from the castings. The worms are then put into new "mother beds" to continue the composting process. Worm castings may be screened before marketing. Worms may be separated for sale by the pound or in bulk to home composters. Vermiculture provides a contained system, the virtual elimination of odors, and pest resistance. This provides higher quality soil products and enhanced market opportunities (Jensen, 1994).

The products that are marketed include soil amendments, worms, worm castings, topsoil blends, worm bins for home composting, and recycled yard debris. The products are sold at The Worm Concern facility, and some gardening stores carry the product labeled under the Worm Gold label. The Worm Concern worked with University of California Cooperative Extension agricultural agents to provide hundreds of tons of mulch for use in orchards. Mulch is placed between orchard rows to a 6-inch depth to provide moisture retention, improved organic matter, and nematode (parasitic worm) suppression.

As part of its marketing efforts, the Worm Concern believes education is one of the keys to its success. The company has developed a "Dr. Rot" school education outreach program titled "Worms Go To School" that reaches over 50 schools. The presentations include an interpretive education specialist, complete worm bins, teacher guides, and classroom activities. Plans are to expand the program into high schools and universities. The firm publishes a quarterly newsletter on vermiculture. In addition to participating in local and community activities, they also hold tours of the facility for schools and the public. They have a compost demonstration area and garden.

\section{Economic Factors and Cost}

The Worm Concern is a private enterprise that sells products from processed wood waste materials as well as educational materials, worm composting bin kits and worms. In 1993, the facility processed 23,725 tons of materials with capital costs of $\$ 500,000$. The capital cost per ton per day capacity was $\$ 5,000$, which results in a $\$ 8-\$ 15$ cost per ton processed. 


\section{Conclusions}

This report has presented an assessment and description of current alternatives to landfills for urban wood waste management; provided guidance on the management of urban wood waste to organizations that produce or manage wood waste including economic, environmental, and operational limitations; and clarified federal and state regulatory and policy positions affecting these organizations ability to properly manage urban wood waste.

Current state regulatory and policy positions affecting urban wood waste management organizations were summarized and presented in the report. The findings indicated that management of urban wood waste in a manner other than landfilling and/or open burning undoubtedly will increase. More than half (30) of the states have implemented some regulations for urban wood waste management. Twenty of the states with regulations either have or are considering prohibiting urban wood wastes from landfills. This upward trend in regulating urban wood waste, which began approximately ten years ago, is in part a function of including urban wood wastes in diversion and recycling rates imposed on (MSW) management systems. Since yard waste $^{6}$ composes at least $16 \%$ of MSW, many state regulatory agencies are prohibiting urban wood waste from sanitary landfill disposal and implementing recycling programs to recover this component of the waste stream to contribute to state recycling and diversion rates.

While there are some regulations at the federal level that have an impact on urban wood waste management, their effect to date has been minimal. The statutes affecting urban wood waste management include: the Clean Air Act, the Resource Conservation and Recovery Act, the Clean Water Act, and the Comprehensive National Energy Policy Act.

Urban wood waste management professionals indicated that the principle incentive for establishing and operating wood waste management systems are increasing number of state, county and local laws and regulations prohibiting the disposal of urban wood waste in sanitary landfills. As regulations and laws are implemented, urban wood waste management organizations have been provided with increased opportunities to contract out wood waste management services with many local governments.

While the opportunities to establish urban wood waste management organizations are increasing, there are also increasing constraints to establishing these programs. Economic factors, meaning the costs involved in the operation and maintenance of an urban wood waste management system, were indicated by urban wood waste professionals as the primary constraint to success $(57.8 \%)$. Economic factors have forced some organizations to operate at the break-even threshold or face closure.

The second leading constraint cited was regulatory and permitting requirements by federal, state, county and local governments $(32.4 \%)$. As regulations and laws are passed to prohibit the disposal of urban wood waste in sanitary landfills, increasingly, the same organizations provided with opportunities to manage urban wood waste have adversely been subjected to increasing laws, regulations and permitting requirements. The difficulty faced by state regulatory agencies with

\footnotetext{
${ }^{6}$ U.S. EPA defines yard waste as "yard trimmings" which includes "grass, leaves and tree brush trimmings from residential, institutional, and commercial sources."
} 
permitting or regulating an urban wood waste management facility often relates to inconsistent or deficient definitions for this relatively new management practice. Many jurisdictions permit and regulate urban wood waste as yard waste or (MSW). Both of these classifications are incompatible with urban wood waste management and make both permitting and siting tedious and costly.

The final category of constraints are community awareness issues $(9.8 \%)$, including public resistance to facility siting and operation; contamination of materials; and odor complaints lodged by citizens. Public relations problems, or the public's perception of urban wood waste management systems were contentious issues but were less significant to the establishment and operation of an urban wood waste management system.

The effect of state initiatives on the generator's ability to find management solutions was considered. Two hundred-seven of 1000 ISA members provided useful information. Fifty-eight percent of these were from states that currently regulate wood waste operations. Of these, $54 \%$ felt that state regulations have decreased the disposal options available, and $27 \%$ indicated that options have stayed the same. The remaining $19 \%$ stated that options have gone up with the implementation of state regulations. Many who stated that they noted no change in disposal options, further indicated that travel distances and tipping fees have increased. Because the majority of information was subjective, no definite conclusions can be drawn regarding national trends in urban wood waste management.

Fourteen organizations engaged in managing wood and wood-related wastes were selected as case studies. The case studies were used to define current management practices and assess the findings of those case studies. Case study sites using several management methods including mulching, composting, combustion, and land application of wood wastes were visited. Subsequently, interviews provided a description of current wood waste management practices and alternatives to traditionally sanctioned practices of open burning and landfilling of these wastes. The results can be used by readers of this report to provide guidance in planning and implementing urban wood waste management programs.

Some of the major finding gathered from the case studies were the number of commonalities that help make the facilities successful. These include the following: tailoring the project within the context of the community in which it is implemented; forming cooperative efforts between and among the public and private sector; maintaining flexibility in both materials processing and products; conducting research into potential markets during the planning stage; undertaking continuous research and experimentation in markets and products; achieving and maintaining a good reputation with the public as a good neighbor and producer of a high quality product; and working closely with local and state regulatory and enforcement officials. 


\section{Appendix A}

\section{PROJECT METHODOLOGY}

\section{Advisory Group}

The project was guided with the assistance of an Advisory Group. Care was taken to bring together a diverse group, representing wood waste generators, managers and regulators. The advisory group consisted of the following: Phil Shepherd of the National Renewable Energy Laboratory, Golden, CO; Dr. Donald Ham and Laura Lynch of the International Society of Arboriculture Research Trust, Savoy, IL; Mary Richards of Maryland Department of Environmental Protection; Jim Legari of Wood Recovery Systems, Fresno, CA; and Clark Gregory, a Monroe, ME-based entrepreneur in composting who participated in the second advisory group meeting.

The advisory group met twice. The first meeting took place via a conference call on July 14, 1994, and discussed these items:

- State regulation tables

- Sample state assessment

- Sample SWANA member assessment

- Sample case study format

- Potential case study sites

The advisory group recommended as follows:

- Summarizing state regulation data into one table and composing a more detailed list

- Consulting ISA Research Trust's first draft of the urban wood waste generation to avoid duplication of effort in both the state and SWANA member assessment

- Concentrating on case study sites that represent diversity in geography, management practices (including the utilization of both simple and sophisticated technology), demographics, management practices for addressing episodic events; and management structure

- Researching facilities that utilize co-combustion as a management method for urban wood wastes

- Researching facilities that manage urban wood waste from utility right-of-way clearing activities.

The second meeting of the advisory group took place at SWANA on September 8, 1994, and covered:

- Description of potential case study sites

- Two pilot case studies

- State and federal regulations

The group reviewed the pilot case studies and concurred that the right information was being collected. Members also concurred that the information on state and federal regulations was 
adequate. The top 21 sites were subdivided into geographic regions. The group was also provided with a one- to two-page description of each of the 21 facilities. The group ranked each facility in each of the regions and made recommendations to investigate other facilities in the Pacific Northwest and Northeast. In addition, recommendations were made to investigate facilities that utilize co-combustion and facilities that utilize different grinding equipment.

\section{State Regulations}

Gathering information from all 50 States was a lengthy, two-step process. First, a current list was assembled that identified State contacts who had direct responsibility for urban wood waste regulations. The starting point was a list provided by the Association of State and Territorial Solid Waste Management Officials (ASTSWMO) that had names, address and phone numbers of people who had responsibility for solid waste management. Then the list was cross checked with SWANA's in-house list of State solid waste regulatory contacts. These agencies were contacted by phone to get the specific person(s) responsible for urban wood waste regulations. Second, with the help of the advisory group, an assessment was developed for use to ascertain specific information on urban wood waste regulation. The assessment was sent out to the 50 States. States that did not returned their completed assessments were contacted by phone. These phone calls usually resulted in resending of the assessment and following up as needed. This process was continued until information was received from every state.

\section{Federal Regulations}

Federal regulations were obtained by researching previous work done on the subject. In addition, research was done using the Bureau of National Affairs database on Federal regulations and the actual Federal regulations as they are enumerated in the Library of Congress.

\section{Opportunities for and Constraints to Establishing or Maintaining Effective Management Programs}

SWANA's database of 5,000+ members was searched to identify members who are more likely to manage urban wood waste. An assessment, again developed with the advisory group, was sent out to over 1,200 recipients. Responses were received from 180 recipients. The assessment asked how much urban wood waste was managed by each facility, what are the constraints that limit the establishment or effectiveness of urban wood waste management programs, what current and future regulations limit the disposal of urban wood waste, and what are the alternatives to landfill disposal.

\section{How State Initiatives Affect the Ability of Urban Wood Waste Generators}

SWANA worked with ISA to obtain a list of members that generate urban wood waste. An assessment was distributed asking how state initiatives affect the ability of urban wood waste generators to find acceptable disposal facilities, and how transportation is affected. SWANA contacted 1000 parties, with information supplied by 207 ISA members.

\section{Current and Future Direction of the Regulation of Urban Wood Waste Management}


Regulatory information was collected from all 50 states using the assessment described above in the Federal Regulation section. The information gathered through the assessment and from other sources was analyzed to reach conclusions about the direction of urban wood waste regulations.

\section{Generation of Urban Wood Waste}

Information was based on the study recently completed by the International Society of Arboriculture Research Trust entitled "Final Report, Urban Tree Residues: Results of the First National Inventory." This study was the first attempt at developing a baseline national estimate of urban wood waste generated by urban forestry-related businesses. Since this study was the first study of its kind, this report was used extensively as a primary source.

\section{Methods of Urban Wood Waste Disposal}

The ISA study described in the Generation of Urban Wood Waste section was used extensively as a primary source.

\section{Assessment of Current Urban Wood Waste Management Practices}

This process took over five months for data gathering, and an additional four months to carry out the site visits. Over 70 potential case study sites were contacted, and information was gathered from over 50 potential case study sites. In addition, the Advisory Group described above provided input and comments on the case study selection process and on the case study format. This whole process is further described below.

\section{Case Study Selection}

A press release describing the project and soliciting information on potential case study sites was distributed to over 300 trade and industry magazines and national organizations. Potential case study sites also were solicited in SWANA's monthly newsletter. A search was performed of all literature relating to wood and wood-waste management in SWANA's Solid Waste Information Clearing House (SWICH), including trade magazines, research papers, and documents.

Researchers acquired lists of facilities that manage urban wood wastes from the state agencies that kept such lists. Researchers also gathered information by attending the 5th Annual National Biofuels Conference and Exhibition, Newton, Massachusetts, Oct. 19-22, 1992, which provided an opportunity for interaction with key players in the biomass industry. In addition, other potential case study sites were identified through networking with callers.

The press release and newsletter solicitation produced over 100 phone inquiries, while the literature search produced over 20 potential sites, and various lists were requested from Conneçticut, New Jersey, Washington, and Oregon. Owing to differences in methodology of classification, these state lists turned out to be only of limited use after many phone calls. In addition, the Advisory Group was very helpful in directing us to sites in the Pacific Northwest and the Northeast, sites that co-combust urban wood wastes, and sites that manage urban wood wastes from utility rightof-way clearing.

After initial contact with potential case study sites, information was solicited from over 70 sites. Information was received from over 50 sites. A short list of 21 sites was compiled utilizing the 
options and methods outlined in the project description and further defined by the advisory group. The criteria outlined in the project description included the following:

- Use of landfills

- Composting systems

- Mulching systems

- Bio-Mass combustion systems

- Bio-Conversion systems

- Co-Management methods

- Recycling options

- Collection and handling practices

- Others

After the second Advisory Group meeting, further research was conducted on the potential case study sites that was recommended by the group. Some of the potential case study sites that the group recommended were disqualified for several reasons, including unsuitable sites, sites that were still under construction, and lack of willingness of the site to participate in the study.

\section{Management Applications that Were Not Included}

\section{Use of Landfills}

Facilities that use landfills as a disposal option for urban wood waste weren't included in the study because landfilling is not a disposal option in states that have banned it. Studying this option would not be helpful to the readers of this study who are looking for alternatives to landfilling.

\section{Biosolids Composting}

There are presently a number of reasons why biosolids composting was not included in this study. While some facilities that compost biosolids, they prefer to use wood chips from pallets rather than urban wood waste. This is largely due to two factors. First, urban wood waste has a high moisture content (whole tree chips have a moisture content of $60 \%$ and mulch has $40 \%-50 \%$ moisture ), and pallet wood has a much lower moisture content (10\% moisture). Since waste wood is used primarily as a bulking agent in this process, a lower moisture content is preferred. Second, urban wood waste tends to have a higher contamination rate on the whole, compared to pallet wood.

\section{Co-Combustion}

Although there are a couple of the case studies sites described in this study that have sold their urban wood waste as a biomass-mass fuel, co-combustion facilities were not included in this study. This is because no co-combustion facilities that use urban wood waste as a primary fuel were found. The main reasons why urban wood waste is not the waste of choice are: its high moisture content; potassium content that causes clinkering and fouling; poor economics compared to large volumes and a consistent product from large-scale silvaculture operations (timber harvesting); and policies that place wood fuel use at the bottom of the "best use" hierarchy. The majority of the biomass fuel that is being used in co-combustion facilities is pallets, construction and demolition wood, industrial wood, and wood from silvaculture activities In Vermont, New Hampshire, and 
Maine, all of which have facilities that use co-combustion, facilities derive their wood fuel component largely from silvaculture activities. For example, the Burlington Power Plant in Vermont, which does use urban waste wood in co-combustion, uses only $1 \%$ of wood fuel from urban tree trimming operations; the rest comes from silvaculture activities. A plant is currently being built in Michigan that will use urban wood waste from the utility right of way clearing from Detroit Edison. But unfortunately, this facility did not want to participate in this study.

Economics is also playing a role in the decreasing use of all types of wood as a biomass fuel. Due to a general oversupply of electricity especially in the Northeast and Northwest, utilities are being forced to reduce the cost of electricity generation. The cheapest energy source is fossil fuels.

\section{Bio-Conversion Systems}

Facilities that utilized bio-conversion weren't included in the study because researchers were unable to locate any facilities that utilize bio-conversion as a disposal option for urban wood waste.

\section{Classification of Case Study Types}

Using the project description, comments from the Advisory Group, and information garnered from our research, we developed the following case study classification types:

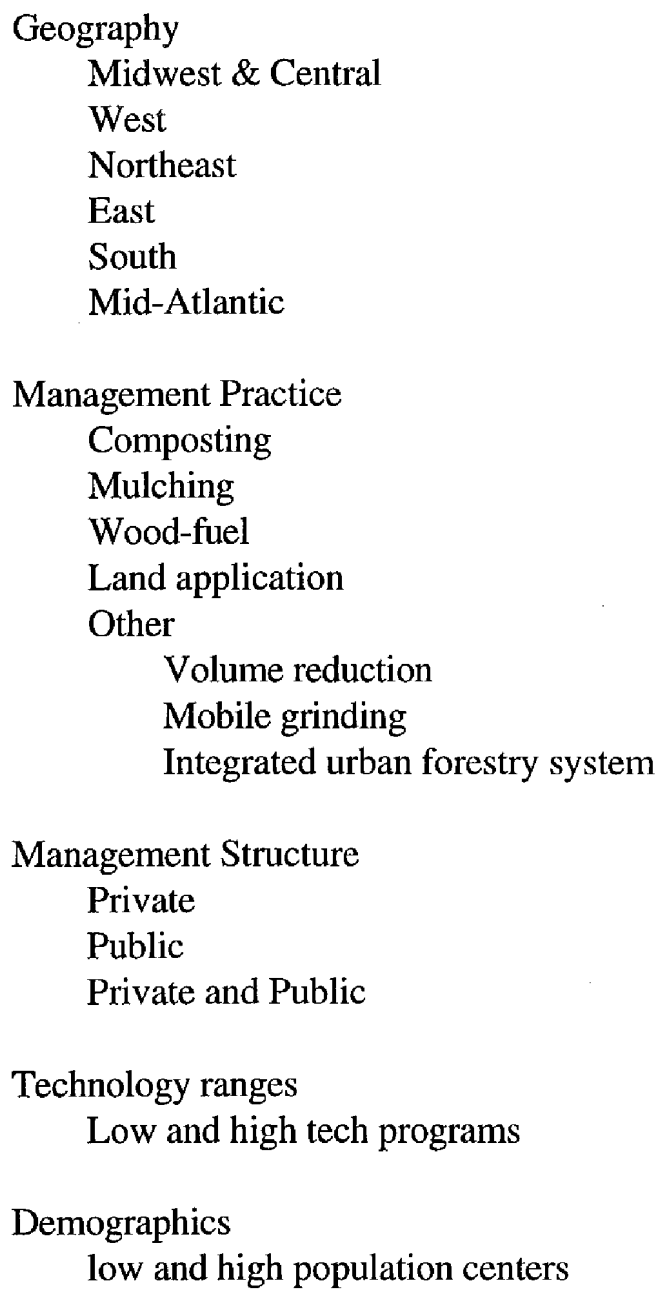


NREL AAE-4-14077-01

\section{Management of Episodic Events}

We decided on this classification because it included the specifics of the project description, comments from the advisory group and our own information. In addition, these main classifications enable the reader to get a clear picture of what is going on each site.

Twelve case study sites in addition to the two pilot case study sites (Prince Georges County, MD, and Carroll County, MD) were selected. 


\section{Appendix B}

\section{Case Study Format}

\section{Project: URBAN WOOD RESIDUE STUDY}

Subject: Structure for Case Studies

\section{ORGANIZATION:}

Contact:

Phone \#:

Address:

Meeting Date:

\section{BACKGROUND:}

When program developed?

Why program developed?

Describe facility (\# acres, gates, buildings):

Material processed:

Type:

Excluded:

Quantity:

Management structure:

Role of private contractors?

\# Employees:

Users of your facility (\%):( landscaper, residential, land clearance):

Regulations affecting operations?

\section{MATERIAL PROCESSING:}

Equipment: List equipment on site that own or rent:

Future needs?

\section{Describe collection process-}

Who-

Schedule-

What-

Equipment

How collected: bags, containers, street-vac 
Curbside, drop-off sites

Specifications of materials accepted (diameter, length)

\section{Procedure to receive materials:}

Scales-

Computer system to track materials

Material storage-

where-

how long until processed-

material separated

Describe processing of the materials:

Pre-Screening:

screen sizes-

Grinding:

Composting-

Turning-

Curing-

Final screening-

Final processing and storage -

Distribution

Quantity-

Service provider-

Marketing-

Public Education

PRODUCT APPLICATION

TESTING \& MONITORING:

Final product:

Compost: aeration

moisture

temperature

Water run-off 
ENVIRONMENTAL

Run-off

Litter

Vectors

Odors

Noise

Contamination

Siting:

Environmental impact statement

ECONOMICS:

Source of funds to operate site

Annual budget

Revenues

product sales

tip fees

landfill

compost facility

grants

Expenses

processing costs:

equipment

cost

maintenance

site cost:

RECOMMENDATIONS: 


\section{Appendix C}

\section{State Contact Listing}

\section{Alabama}

Russell A. Kelly, Chief

Solid Waste Branch

Land Division

Department of Environmental Management

P.O. Box 301463

Montgomery, AL 36130-1463

\begin{abstract}
Alaska
Glenn Miller, Manager

Solid Waste Management Section

Division of Environmental Quality

Department of Environmental Conservation 410 Willoughby Avenue Suite 105

Juneau, AK 99801-1795
\end{abstract}

\section{Arizona}

Dan Zeller, Manager

Solid Waste Section

Office of Waste Programs

Arizona Department of Environmental

Quality

3033 North Central Avenue, Fifth Floor

Phoenix, AZ 85004

\section{Arkansas}

Mike Hood, Tech. Asst. Manager

Solid Waste Division

Department of Pollution Control and Ecology

8001 National Drive

PO Box 8913

Little Rock, AR 72219-8913

\section{California}

Scott Walker

Executive Director

California Integrated Waste Management

Board

8800 Cal Center Drive

Sacramento, CA 958264

\section{Colorado}

Pamela Harley, Manager

Solid Waste and Storage Tank Mgt.

Programs

Hazardous Materials and Waste Mgt.

Division

Colorado Department of Health

4300 Cherry Creek Drive South

Denver, CO 80222-1530

\section{Connecticut}

Earl Beebe

Planning and Standards

Department of Environmental Protection

79 Elm Street

Hartford, CT 06106-5127

\section{Delaware}

Bob Hartman

Solid Waste Branch

89 Kings Highway

P.O. Box 1401

Dover, DE 19903

\section{Washington DC}

Janice Eggleston

Office of Recycling

65 K St. N.E.

Washington, D.C. 20002

\section{Florida}

Francine Jowel

Division of Waste Management

Department of Environmental Protection

Twin Towers Office Building '

2600 Blair Stone Road

Tallahassee, FL 32399-2400

\section{Georgia}

Harold Gillispie

Environmental Protection Division

Georgia Department of Natural Resources

4244 International Parkway, Suite 100 
Atlanta, GA 30354

Hawaii

John Harder, Coordinator

Solid Waste and Hazardous Waste Branch

Environmental Management Division

Department of Health

Five Waterfront Plaza

500 Ala Moana Blvd., Suite 250

Honolulu, HI 96813

\section{Idaho}

Kathy Sewell, Program Manager

Department of Health and Welfare

Division of Environmental Quality

1410 North Hilton Street, second floor

Boise, ID 83706

\section{Illinois}

Michael Nechvatal, Manager

Solid Waste Management Section

Bureau of Land

Illinois Environmental Protection Agency

2200 Churchill Road, P.O. Box 19276

Springfield, IL 62794-9276

\section{Indiana}

Wendy Hoffspiegel

Solid Waste Branch

Department of Environmental Management

Office of Solid and Hazardous Waste

Management

100 North Senate Ave., P.O. Box 1605

Indianapolis, IN 46206-6015

\section{Iowa}

Tom Collins

Land Quality Bureau

Iowa Department of Natural Resources

900 East Grand Avenue

Wallace Building

Des Moines, IA 50319

\section{Kansas}

Thomas Gross, Chief

Solid Waste Section

Department of Health and Environment

Division of Environment

Forbes Field

Building 740
Topeka, KS 66620

\section{Kentucky}

George Gilbert, Manager

Solid Waste Branch

Division of Waste Management

Department for Natural Resources

14 Reilly Road

Frankfort, KY 40601

\section{Louisiana}

Solid Waste Division

Office of Solid and Hazardous Waste

Dept. of Environmental Quality

1720 Airline Highway

Baton Rouge, LA 70817

\section{Maine}

Jim Glasgow

Maine WMA

Department of Environmental Protection

Div. of Solid Waste Facilities Reg.

State House Station 154

Augusta, ME 04333

\section{Maryland}

Mary Richmond, Section Head

Permits/Compliance

Maryland Department of the Environment

Hazardous and Solid Waste Management

Administration

2500 Broening Highway

Baltimore, MD 21224

\section{Massachusetts}

Philip Weinberg, Director

Division of Solid Waste

Department of Environmental Protection

One Winter Street, 4th Floor

Boston, MA 02108

\section{Michigan}

Karl Zollner Jr., Chief

Waste Management Division

Department of Natural Resources

P.O. Box 30241

Lansing, MI 48909 
Carson City, NV 89710

\section{Minnesota}

Robert Wirth

Ground Water and Solid Waste Division

Minnesota Pollution Control Agency

520 Lafayette Road, North

St. Paul, MN 55155-4194

\section{Mississippi}

Billy Warden, Coordinator

Department of Natural Resources

Office of Pollution Control

P.O. Box 10385

2380 Highway 80 West

Jackson, MS 39289-0385

\section{Missouri}

Warner Shermen, Environmental Engineer

Solid Waste Management Program

Department of Natural Resources

Division of Environmental Quality

205 Jefferson Street

P.O. Box 176, 10 Floor

Jefferson City, MO 65102

\section{Montana}

Edward Thamke

Solid Waste Program

Department of Health and Environmental

Sciences

Solid and Hazardous Waste Bureau

P.O. Box 200901

Helena, MT 59620

\section{Nebraska}

David Haldeman, Supervisor

Waste Recovery Section

Air and Waste Management Division

Department of Environmental Control

Land Quality Division

P.O. Box 98922

Lincoln, NE 68509-8922

\section{Nevada}

Gene Klara, Supervisor

Division of Environmental Protection

Bureau of Waste Management

333 West Nye Lane, Capitol Complex

\section{New Hampshire}

Mark Lennon

Solid Waste Compliance

Waste Management Division

Dept. of Environmental Services

6 Hazen Drive

Concord, NH 03301

\section{New Jersey}

Steven Rinaldi

Bureau of Recycling

Department of Environmental Protection

and Energy

840 Bear Tavern Road, CN 414

Trenton, NJ 08625

\section{New Mexico}

Dave Duran, Program Manager

Permitting and Compliance

Solid Waste Bureau

Environmental Protection Division

New Mexico Environment Department

P.O. Box 26110

Santa Fe, NM 87502

\section{New York}

John Willson

Division of Solid Waste

New York Department of Environmental

Conservation

50 Wolf Road

Albany, NY 12233-4010

\section{North Carolina}

Ted Lyon

Solid Waste Section

Division of Solid Waste Management

North Carolina Department of Environment, Health \& Natural Resources

401 Oberlin Road, P.O. Box 27687

Raleigh, NC 27611-7687 


\section{North Dakota}

Kevin Solie, Environmental Scientist

Solid Waste Program

Division of Waste Management

State Department of Health and

Consolidated Laboratories

Box 5520

Bismarck, ND 58502-5520

\section{Ohio}

Alison Shockley

Division of Solid and Infectious Waste Mgt.

Ohio Environmental Protection Agency

P.O. Box 163669

Columbus, $\mathrm{OH}$ 43216-3369

\section{Oklahoma}

Jim Warren

Solid Waste Management Service Department of Environmental Quality 1000 N.E. 10th Street

Oklahoma City, OK 73117-1212

\section{Oregon}

Bill Bree

Solid Waste Planning Programs

Hazardous and Solid Waste Division

Department of Environmental Quality

811 S.W. Sixth Avenue

Portland, OR 97204-1390

\section{Pennsylvania}

Tom Woy, SW Program Specialist

Division of Municipal and Residual Waste

Bureau of Waste Management

Department of Environmental Resources

P.O. Box 8472

Harrisburg, PA 17105-8742

\section{Rhode Island}

Chris Schaffer

Waste Management Branch

Department of Environmental Management

Division of Air and Hazardous Materials

291 Promenade Street

Providence, RI 02908-5767

\section{South Carolina}

April Grunsky, Facilities Engineer

Bureau of Solid and Hazardous Waste

Management

Department of Health and Environmental

Control

2600 Bull Street

Columbia, SC 29201

\section{South Dakota}

David Templeton, Administrator

Waste Management Program

Department of Environment and Natural

Resources

Division of Environmental Regulation

523 East Capitol

Pierre, SD 57501-3181

\section{Tennessee}

Joyce Dunlap, Supervisor

Solid Waste Assistants

Department of Environment and

Conservation

Division of Solid Waste Management

14th Floor, L \& C Tower

401 Church Street

Nashville, TN 37243-0455

\section{Texas}

Hector Mendieta, Manager Technical

Assistance

(MSW) Division

TNRCC

P.O. Box 13087, Capitol Station

Austin, TX 78711

Utah

Ralph Bohn, Chief

Bureau of Solid and Hazardous Waste

Division of Environmental Health

288 North 1460 West, P.O. Box 144880

Salt Lake City, UT $84118-4880$

Vermont

Andrea Cohen

Solid Waste Management Division

Department of Environmental Conservation 
103 South Main Street

Waterbury, VT 05671-0407

Virginia

Ulysses Brown, SW Compliance Manager

Department of Environmental Quality

P.O. Box 10009

Richmond, VA 23240-0009

Washington

Dave Nightingale

Solid Waste Services Section

Waste Management Programs

WA Dept. of Ecology

P.O. Box 47600

Olympia, WA $98504-7600$

\section{West Virginia}

Charles Capet

13 Office of Waste Management

Solid Waste Management Section

Division of Natural Resources

Department of Commerce, Labor and

Environmental Resources

Waste Management Section

1356 Hansford Street

Charleston, WV 25301

\section{Wisconsin}

Laksmi Sridharan, Chief

Solid Waste Management Section

Bureau of Solid and Hazardous Waste

Management

Division of Environmental Quality

Department of Natural Resources

P.O. Box 7921

Madison, WI 53707

\section{Wyoming}

Carl Anderson, Regional Supervisor

Division of Solid and Hazardous Waste

Department of Environmental Quality

122 West 25th Street

Cheyenne, WY 82002

\section{Puerto Rico}

Flor Del Valle, Director

Land Pollution Area

Environmental Quality Board

Office of Governor
P.O. Box 11488

Santurce, PR 00910

U.S. Virgin Islands

May Cornwall

Division of Environmental Protection

Department of Public Works

Government of the Virgin Islands

6002 Anna's Hope

Christiansted, St. Croix, VI 00820-4428 


\section{References}

Environmental Risk Limited and C.T. Donovan Associates Inc. (November, 1992). Wood Products in the Waste Stream: Characterization and Combustion Emissions. Contract No. 1531-ERER-ER-91. Report 98-8 Vol. 1. pp. 2-29,2-30.

Federal Register. (July 1, 1994). “257.2 Definitions." Code of Federal Regulations 40 Parts 260 to 299 . Washington, DC. pp. 357-358.

Glenn, Jim. (March, 1990). "The State of Garbage in America." Biocycle (33:3); pp. 48-53.

Governmental Institutes, Inc. (February, 1992). Environmental Statutes, 1992 edition. Governmental Institutes, Inc. Rockville, MD. pp. 3-574.

Grobe, Karin. (May, 1994). "Direct Landscaping of Yard Trimmings." Biocycle (35:5); pp. 60-62.

Helmecki, Dave. (1994). Prince George s County Processing Facilities informational sheet. pp. 1-4.

Jensen, Jim. (May, 1994). "The worms crawl in, the worms crawl out...". Resource Recycling (13:5); pp. 22-29.

Morehead, Cindy. (1994). Decatur-Morgan County Landfill informational fact sheet. pp. 1-2.

NEOS Corporation. (September, 1994). Urban Tree Residues: Results of the First National Inventory. CO: ISA Research Trust, Allegheny Power System, and National Arborist Foundation. Work performed by NEOS Corporation, Lakewood, CO. pp. 33-38.

“Quantifying Yard Trimmings Output." (March, 1994). Biocycle (35:3); p. 18.

Ragsdale, James V.; Stasis, Peter; Rudd, Michael; and Bradshaw, Joan. (September, 1992). "Mulch Production From Yard Trash." Biocycle (33:9); pp. 34-37.

SWANA. (April, 1993). "Defining The (MSW) Management Infrastructure." $\quad$ Section T-24 in SWANA Technical Policy Position. Section T-24. p. 3.

U.S. Environmental Protection Agency. (November, 1994). Characterization of Municipal Solid Waste in the United States: 1994 Update. \# EPA530-R-94-042. U.S. EPA Municipal and Industrial Solid Waste Division-Office of Solid Waste, Washington, DC. pp. 4-6. 


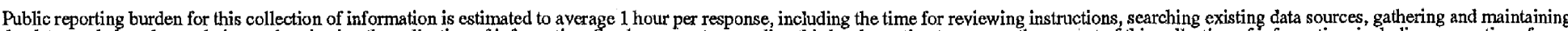

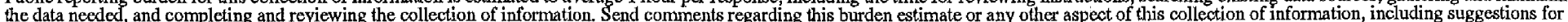

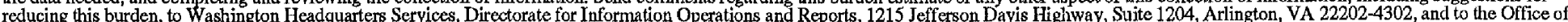
Management and Budget, Paperwork Reduction Project (0704-0188), Washington, DC 20503.

\begin{tabular}{|l|c|c|}
\hline $\begin{array}{l}\text { 1.AGENCY USE ONLY (Leave } \\
\text { blank) }\end{array}$ & $\begin{array}{c}\text { 2. REPORT DATE } \\
\text { February 1996 }\end{array}$ & $\begin{array}{c}\text { 3. REPORT TYPE AND DATES COVERED } \\
\text { Final Subcontract Report }\end{array}$
\end{tabular}

4. TITLE AND SUBTITLE

An Assessment of Management Practices of Wood and Wood-Related Wastes in the Urban Environment

6. AUTHOR(S)

Solid Waste Association of North America

7. PERFORMING ORGANIZATION NAME(S) AND ADDRESS(ES)

Solid Waste Association of North America

1100 Wayne Ave.

Suite 700

Silver Spring, MD 20910

9. SPONSORING/MONITORING AGENCY NAME(S) AND ADDRESS(ES)

National Renewable Energy Laboratory

1617 Cole Blvd.

Golden, CO 80401
5. FUNDING NUMBERS

(C) AAE-4-14077-01

(TA) WM41.1010

8. PERFORMING ORGANIZATION REPORT NUMBER

DE96000534

10. SPONSORING/MONITORING AGENCY REPORT NUMBER

NREL/TP-430-20696

\section{SUPPLEMENTARY NOTES}

NREL technical monitor: Philip Shepherd, (303) 275-2929

12a. DISTRIBUTION/AVAILABILITY STATEMENT

National Technical Information Service

U.S. Department of Commerce

5285 Port Royal Road

Springfield, VA 22161 12b. DISTRIBUTION CODE

UC-1400

\section{ABSTRACT (Maximum 200 words)}

Report documents a study on urban yard waste, which is $16 \%$ of the municipal solid waste stream. Current alternatives are given to landfilling urban wood waste, and management practices are outlined. State and federal regulations are summarized.
14. SUBJECT TERMS
15. NUMBER OF PAGES

urban wood wastes, yard waste, solid waste management

16. PRICE CODE

17. SECURITY CLASSIFICATION OF REPORT
18. SECURITY CLASSIFICATION OF THIS PAGE
19. SECURITY CLASSIFICATION OF ABSTRACT
20. LIMITATION OF ABSTRACT 